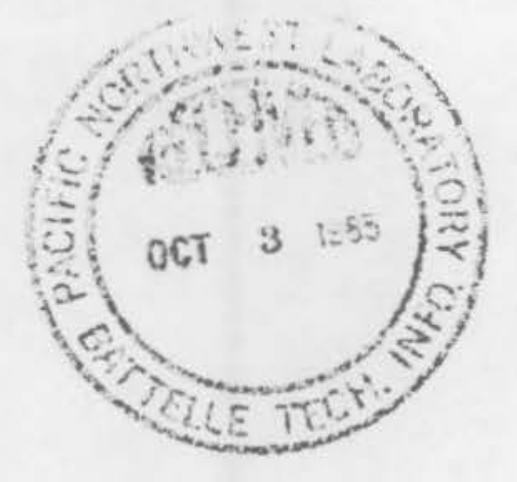

\title{
Gas Leak Characteristics of Inner Packaging Components Used in the D0T-Spec 6M Container
}

\author{
J. M. Taylor
}

September 1985

Prepared for the U.S. Department of Energy under Contract DE-AC06-76RLO 1830

Pacific Northwest Laboratory Operated for the U.S. Department of Energy by Battelle Memorial Institute 


\title{
DISCLAIMER
}

This report was prepared as an account of work sponsored by an agency of the United States Government. Neither the United States Government nor any agency thereof, nor any of their employees, makes any warranty, express or implied, or assumes any legal liability or responsibility for the accuracy, completeness, or usefulness of any information, apparatus, product, or process disclosed, or represents that its use would not infringe privately owned rights. Reference herein to any specific commercial product, process, or service by trade name, trademark, manufacturer, or otherwise, does not necessarily constitute or imply its endorsement, recommendation, or favoring by the United States Government or any agency thereof. The views and opinions of authors expressed herein do not necessarily state or reflect those of the United States Government or any agency thereof.

\author{
PACIFIC NORTHWEST LABORATORY \\ operated by \\ BATTELLE \\ for the \\ UNITED STATES DEPARTMENT OF ENERGY \\ under Contract DE-AC06-76RLO 1830
}

\begin{tabular}{|c|c|}
\hline \multicolumn{2}{|c|}{ Printed in the United States of America } \\
\hline \multicolumn{2}{|c|}{ Available from } \\
\hline \multicolumn{2}{|c|}{ Uniled States Department of Commerce } \\
\hline 5285 & \\
\hline \multicolumn{2}{|c|}{ Springtield, Virginia 22161} \\
\hline \multicolumn{2}{|c|}{ NTIS Price Codes } \\
\hline \multicolumn{2}{|c|}{ Microfiche A01 } \\
\hline \multicolumn{2}{|c|}{ Printed Copy } \\
\hline & Price \\
\hline Pages & Codes \\
\hline $001-025$ & A02 \\
\hline $026 \cdot 050$ & $\mathrm{~A} 03$ \\
\hline 051.075 & AO4 \\
\hline $076-100$ & A05 \\
\hline $101-125$ & A06 \\
\hline $126-150$ & AO7 \\
\hline $151-175$ & A08 \\
\hline $176-200$ & $A 09$ \\
\hline $201-225$ & A010 \\
\hline $226-250$ & $A 011$ \\
\hline $251-275$ & A012 \\
\hline $276-300$ & A013 \\
\hline
\end{tabular}


PNL -5591

UC-71

\section{5}

GAS LEAK CHARACTERISTICS OF INNER PACKAGING COMPONENTS USED IN THE DOT-SPEC 6M CONTAINER

J. M. Taylor

September 1985

Prepared for

the U.S. Department of Energy

under Contract DE-AC06-76RLO 1830

Pacific Northwest Laboratory

Richland, Washington 99352 



\section{SUMMARY AND CONCLUSIONS}

A test program was conducted by Pacific Northwest Laboratory(a) to determine the gas leak characteristics of metal food pack cans and $2 R$ vessels used to package radioactive material in a DOT $6 M$ specification container. The $2 R$ vessels tested had either pipe cap or pipe plug closures with standard taper pipe threads. None of the $2 R$ vessels tested had male threads that were within the pipe thread specification; the female threads were not gauged because of the lack of gauging equipment. A variety of luting compounds were tested by applying the compounds to the threads of the $2 R$ vessel to determine if a gas-tight seal could be obtained under elevated temperature and pressures. A silicon rubber compound proved to be a superior luting compound. The silicon rubber compound produced gas tight seals $\left(<10^{-5} \mathrm{cc} / \mathrm{sec}\right.$ ) on pipe assemblies that could not be sealed with other luting compounds. The gas-tight seal was maintained to temperatures of $300^{\circ} \mathrm{F}$ and $100 \mathrm{psig}$ when the pipe cap or plug was tightened with a torque in excess of $100 \mathrm{ft}-1 \mathrm{~b}$.

The gas leak characteristics of the metal food pack cans tested depended on the quality of the mechanical crimp seal. If high-quality seals were obtained, leak rates as low as $3.5 \times 10^{-8} \mathrm{~atm}-\mathrm{cc} / \mathrm{sec}$ were achieved. Cans that had leak rates $<2 \mathrm{cc} / \mathrm{sec}$ were made gas tight by applying a silicon rubber compound to the seams. Applying the silicon rubber compound to the can seams enabled the cans to remain gas tight up to pressures of 35 psig. Depending on the type of lids used, the lids deformed irreversibly at different pressures. The flat profile lids deformed at $7 \mathrm{psig}$, and the ribbed reinforced lids (concentric ring type) deformed irreversibly above $15 \mathrm{psig.}$ To maintain gas tight seals, permanent deformation of the lids should be avoided.

The cans failed under pressures between 25 to 89 psig depending on the quality of the crimp seal. The lids failed either by uncrimping or by the lid tearing along the juncture between the can wall and the lid.

(a) Pacific Northwest Laboratory is operated by Battelle Memorial Institute for the U. S. Department of Energy. 
Severał packaging configurations were tested under accident conditions specified in 10 CFR 71.73 to determine which configuration would best protect the product cans inside the $2 R$ vessel of the $6 M$ container. A packaging configuration was developed using spacer plates and empty slip lid cans as impact absorbers that protected the product cans inside a $6 \mathrm{M}$ container from damage during a 30-foot drop on an unielding surface.

It can be concluded from the tests performed that the inner packaging components ( $2 R$ vessel, metal product cans) used with a $6 M$ container can be sealed so that they will be gas tight $\left(<10^{-5} \mathrm{cc} / 5 \mathrm{ec}\right)$ under elevated temperature and pressure and impact conditions.

To maintain gas tight seals under accident conditions, the metal cans must be sealed with a properly adjusted can-sealing machine; the threads of the $2 R$ vessel must be luted with a sealing compound such as a silicone rubber compound; and the metal cans must be protected inside the $2 R$ vessel with spacer plates and impact absorbers. 


\section{FIGURES}

1 DOT Specification 6 M Container.......................... 2

2 Typical $2 R$ Vessels with Pipe Cap - Pipe Plug Closures....... 4

3 Basic Form of USA Standard Taper Pipe Thread............... 5

4 USA Standard Taper Pipe Thread Notation................... 6

5 Thread Profile of a New 5 -in. Pipe Body $Y(\sim 50 x) \ldots \ldots \ldots \ldots .7$

6 Thread Profile of a New $5-i n$. Pipe Body A $(\sim 50 x) \ldots \ldots \ldots \ldots .6$

7 Thread Profile of an 01d Pipe Body $(\sim 50 \mathrm{x}) \ldots \ldots \ldots \ldots \ldots \ldots \ldots, \quad 8$

8 Thread Profile of a New Pipe Plug $(20 \mathrm{x}) \ldots \ldots \ldots \ldots \ldots \ldots \ldots . . . .6$

9 Thread Profile of an 01d Pipe Plug $(250 x) \ldots \ldots \ldots \ldots \ldots \ldots . . .6$

10 Thread Profile of a Pipe with Thread Damage $(\sim 50 \mathrm{x}) \ldots \ldots \ldots \ldots . .11$

11 Low Magnification (3x) Photograph of Pipe Body Y........... 11

12 Minor Thread Damage on Pipe Cap........................ 12

13 Thread Damage of 01d Pipe Body $\ldots \ldots \ldots \ldots \ldots \ldots \ldots \ldots \ldots, 12$

14 Apparatus Used for Vacuum Bubble Testing 2R Vessels........ 15

15 Apparatus Used for Bubble Testing $2 R$ Vessels at

Elevated Pressures.................................. 15

16 Apparatus Used for Bubble Testing $2 R$ Vessels at

Elevated Temperature and Pressure..................... $\quad 16$

17 Pipe Cap Fixture Used to Torque Pipe Caps on Pipe Bodies.... 16

18 Pipe Plug Fixture Used to Torque Pipe Plugs on Pipe Tubes... 17

19 Various Size Cans Used in Pressure Tests................. 17

20 Cross Section of a Crimp-Sealed Lid on a Food Pack Can...... 19

21 Cross Section of the Side Seam of a Food Pack Can........... 19

22 Seams of Food Pack Cans Coated with Silicone Rubber

Compound......................................... 21

23 Apparatus Used for Bubble Testing Crimp-Sealed Cans......... 21

24 Apparatus Used to Bubble Test Crimp-Sealed Cans at

Elevated Pressures.................................. 22 


\section{CONTENTS}

SUMMARY AND CONCLUSIONS $\ldots \ldots \ldots \ldots \ldots \ldots \ldots \ldots \ldots \ldots \ldots \ldots \ldots \ldots \ldots \ldots \ldots \ldots \ldots \ldots$

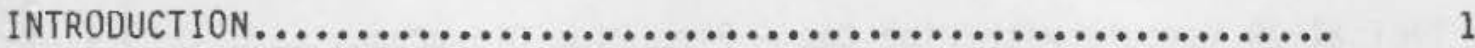

TEST BASIS AND HARDWARE DESCRIPTION $\ldots \ldots \ldots \ldots \ldots \ldots \ldots \ldots \ldots \ldots \ldots \ldots$

2R INNER CONTAINMENT VESSEL $\ldots \ldots \ldots \ldots \ldots \ldots \ldots \ldots \ldots \ldots \ldots \ldots \ldots \ldots \ldots \ldots \ldots$

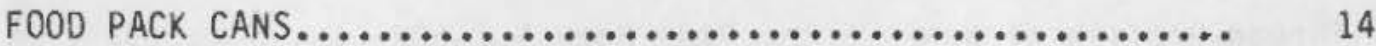

IMPACT AND HEATING TESTS $\ldots \ldots \ldots \ldots \ldots \ldots \ldots \ldots \ldots \ldots \ldots \ldots \ldots . \ldots \ldots$

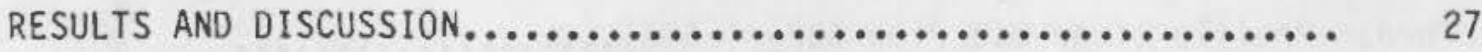

$2 R$ INNER CONTAINMENT VESSELS $\ldots \ldots \ldots \ldots \ldots \ldots \ldots \ldots \ldots \ldots \ldots \ldots . \ldots \ldots \ldots$

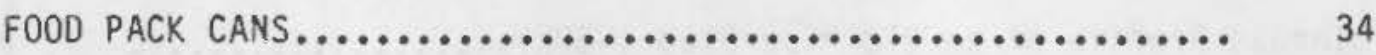

IMPACT AND HEATING TESTS......................... 39

REFERENCES....................................... 45

APPENDIX A - CORRESPONDENCE BETWEEN NRC AND DOT ............ A.I

APPENDIX B - INSTRUCTIONS FOR PROPERLY ADJUSTING SEALING

MACHINCES ..................................... 8.1

APPENDIX C - OPERATING PROCEDURES..................... c.. 
Cross Section of DOT-6M Containers Showing Packaging Configurations Used to Protect the Metal Cans During

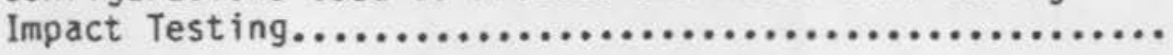

Cross Section of D0T-6M Container Showing Packaging Configuration Used to Protect the Metal Cnas During

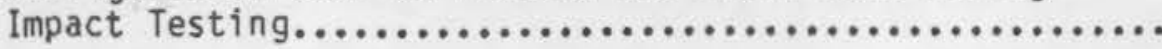

27 Drop Test Facility for Impact Testing of 6M Containers......

28 Thread Profile of Pipe Body Y After Repeated Openings

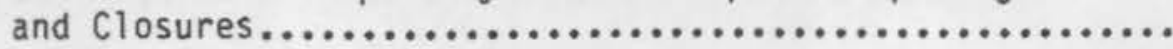

29 Comparison of the Amount of Deformation of Different Size Metal Cans after Pressurization..................

30 The Volume Change of Metal Cans 4-1/16-in.D $\times 4-11 / 16-i n . H$ Under Pressure...................................

31 The Volume Change of Metal Cans 4-4/16-in. D x 7-in. H

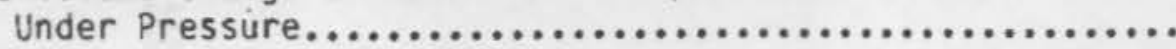

33 Lid Failure by Uncrimping Under Pressure.................

34 Damage to $6 M$ Container After 30 -Foot End-On Impact..........

35 Damaged Metal Can Containing Sand After First 30-Foot Impact Test................................... 40

36 Damaged Larger Metal Can After First 30-Foot Impact Test.... 


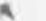


GAS LEAK CHARACTERISTICS OF INNER PACKAGING COMPONENTS

USED IN THE DOT-SPEC 6M CONTAINER

\section{INTRODUCTION}

This report describes the testing that was done to determine the gas leak characteristics of screw-type $2 R$ inner containment vessels of the $6 M$ container and of the food pack cans used to package the radioactive material placed in the $2 R$ vessels. This testing was performed by Pacific Northwest Laboratory for the U.S. Department of Energy.

The Department of Transportation Specification 6M containers (Figure 1) are currently approved by the Department of Energy (DOE), the Nuclear Regulatory Commission (NRC) and the Department of Transportation (DOT) for packaging of Type $B$ quantities of solid radioactive material. Recently, the NRC expressed concern to the DOT (see Appendix A) that the inner containment vessel ( $2 R$ vessel) of the $6 M$ container may not be adequate to meet current regulations for Type $B$ packaging. In particular, the NRC indicated that the requirements of 10 CFR Part 71.52 , concerning no loss or dispersal of radioactive material to a sensitivity of $10^{-6} \mathrm{~A}_{2}$ quantity per hour under normal conditions of transport or an $A_{2}$ quantity per week under hypothetical accident conditions, have not been demonstrated. To determine if the inner packaging components could meet the above requirements, the metal cans and $2 R$ vessels were subjected to pressure, impact, and heating tests.

The leakage tests were conducted with $2 R$ vessels having screw-type fittings. The testing was confined to these types of vessels because the majority of $6 M$ containers currently in use have $2 R$ vessels with screw-type closures (caps and plugs). The testing was also confined to the 30 -gallon size $6 M$ containers because it is the most common size used by DOE contractors.

The sections that follow describe the testing that was performed, the food pack cans and $2 R$ vessels, the sealing methods used to obtain gas tight seals, and the results of the testing. Instructions for properly adjusting can sealers to obtain hermetic seals are provided in Appendix B. Appendix C outlines procedures for sealing $2 R$ vessels and metal cans. 


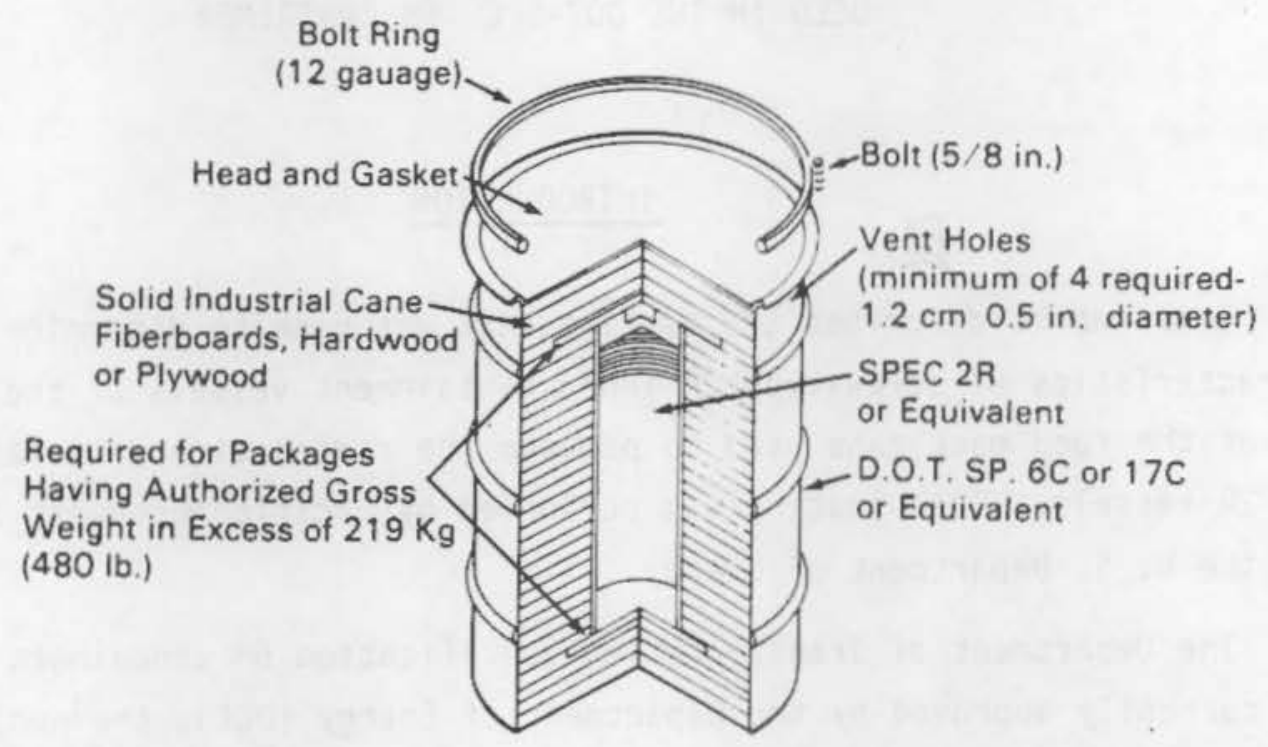

FIGURE 1. DOT Specification $6 \mathrm{II}$ Container 


\section{TEST BASIS AND HARDWARE DESCRIPTION}

Containers that are approved for packaging sizable amounts of radioactive materials must meet certain test criteria, such as hypothetical accident conditions. These conditions consist of dropping the container 9 meters ( 30 feet) onto an unyielding surface, followed by a drop of 1 meter onto a cylinder 15 centimeters ( 6 inches) in diameter and 20 centimeters ( 8 inches) long. After these tests, the package is exposed to a high-temperature environment (usually a fire) of $800^{\circ} \mathrm{C}\left(1475^{\circ} \mathrm{F}\right)$ for 30 minutes. If the packaye contains fissile material such as plutonium or enriched uranium, the packaye must next be immersed under a head of water 0.9 meters ( 3 feet) for eight hours. A separate immersion test on an undamaged package must also be performed. This consists of immersing the container under 15 meters (50 feet) of water for eight hours. All these tests must be conducted sequentially. The test requirements are spelled out in detail in the Code of Federal Regulations (CFR) Title 10 Part 71.73. If, after these tests, the package does not leak radioactive material exceeding a total amount of $A_{2}(a)$ in one week, it can qualify as a Type B container.

The NRC has indicated that the ANSI N14.5 standard (NRC 1975) describes acceptable test methods to demonstrate radioactive material leakage below the values listed above. ANSI N14.5 describes methods for converting maximum permissible material leakage rates to that of a gas leak rate. The standard defines leak tightness as a gas leak rate below $10^{-7} \mathrm{~atm} \mathrm{cc} / \mathrm{sec}$.

To determine if the metal cans and the $2 R$ vessels could meet the gas leak rate standards, they were sealed and pressure tested at room temperature and also at $300^{\circ} \mathrm{F}$. The cans inside the $2 R$ vessels were also loaded into $6 \mathrm{M}$ drums and subjected to 30-foot drops, with subsequent heating (300\% $\mathrm{F}$ ) of the $2 R$ vessel. The furnace heating of the $2 R$ vessel to $300^{\circ} \mathrm{F}$ simulated the temperatures achieved during the fire test. It has been shown (Chalfant 1984) that the $2 \mathrm{R}$ vessel inside a $6 \mathrm{M}$ container heats to less than $300^{\circ} \mathrm{F}$ during fire tests, if the radioactive material packaged inside the $2 R$ vessel does not exceed 10 watts of thermal output. The puncture and the immersion tests were

(a)For definitions of $A_{2}$ quantity see 49 CFR 173.403 (b). 
omitted from the required sequential test series because these tests would not damage the $2 R$ vessel or the metal cans sufficiently to have an effect on the leak rate characteristics of these components.

\section{R INNER CONTAINMENT VESSEL}

The specification for the $2 R$ inner containment vessel is stated in the 49 CFR Part 178.34. The specification states that the ends of the vessel must be fitted with screw-type or flange-type closures. One end of the vessel may be permanently closed by a welded plate.

Typical $2 R$ vessels with threaded closures are shown in Figure 2. Almost all the $2 R$ vessels presently in use with the cap closure are made from a standard 5-inch pipe with an inside diameter of 5.047 inches and an outside diameter of 5.563 inches. The $2 R$ vessel with the plug closure is made from tubing having an inside diameter of 5.250 inches and an outside diameter of 5.750 inches. The specification allows different sizes of $2 R$ vessels as long as the inside diameter does not exceed 12 inches. Another limitation on the size of the $2 R$ vessel is the minimum thickness of the insulation media inside the $6 \mathrm{M}$ drum. The inner vessel must be protected by at least 3.75 inches of insulation material.

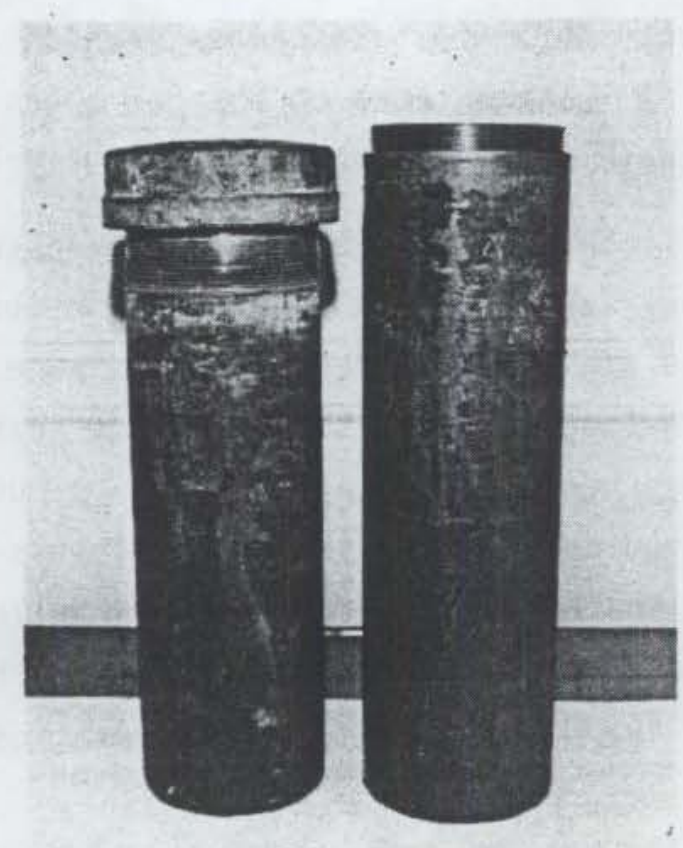

FIGURE 2. Typical 2R Vessels with Pipe Cap Pipe Plug Closures 
The screw-type closure can be either caps or plugs and the number of threads per inch must not be less than that specified for the USA standard taper pipe thread. The types of threads used on pipe and pipe fittings may be classed according to their intended use. The threads for $2 R$ vessels, caps and plugs are intended to produce pressure-tight joints when assembled with a sealer or luting compound. The basic form of the USA standard taper pipe thread is shown in Figure 3. The tolerances for a 5 -inch schedule 40 pipe thread are given in Table 1 . The basic pitch diameter $\left(E_{0}\right)$ of a taper thread is determined by the following formula.

$$
\begin{aligned}
E_{0} & =D-(0.050+1.1) p \\
\text { where } & =\text { outside diameter of pipe } \\
E_{0} & =\text { pitch diameter of thread at end of pipe } \\
P & =\text { thread pitch. }
\end{aligned}
$$

The location of the pitch diameters is shown in Figure 4.

\section{TABLE 1. Tolerances on 5-1nch External and} Internal Taper Pipe Threads, NPT

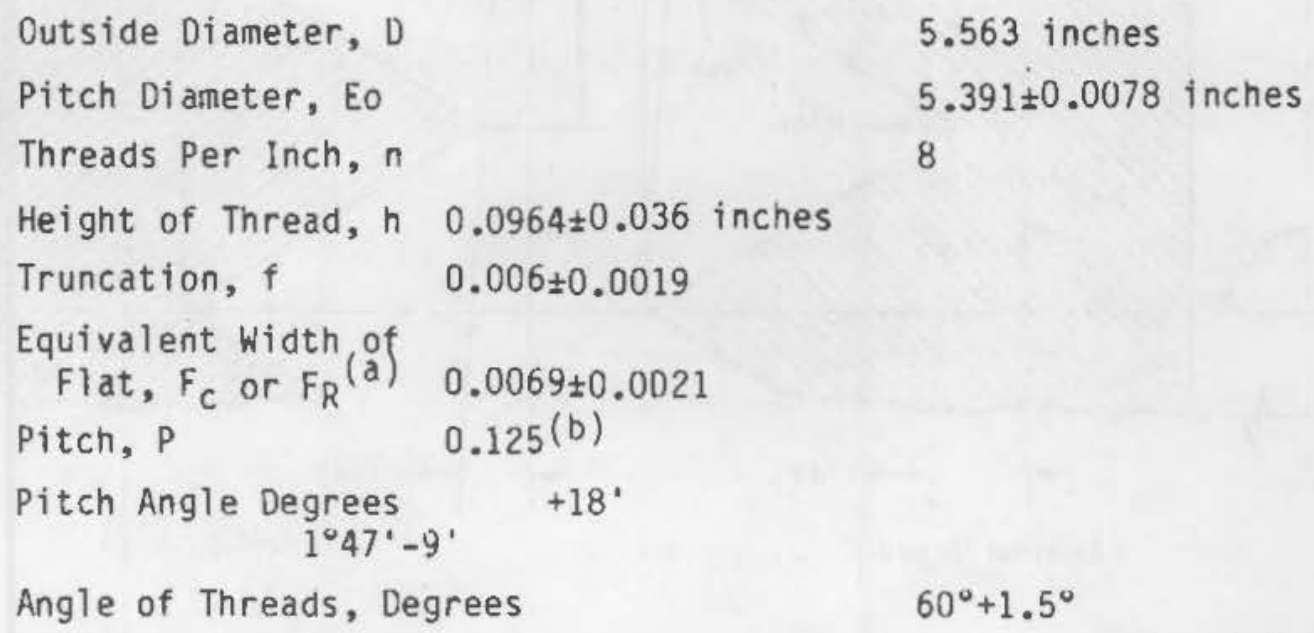




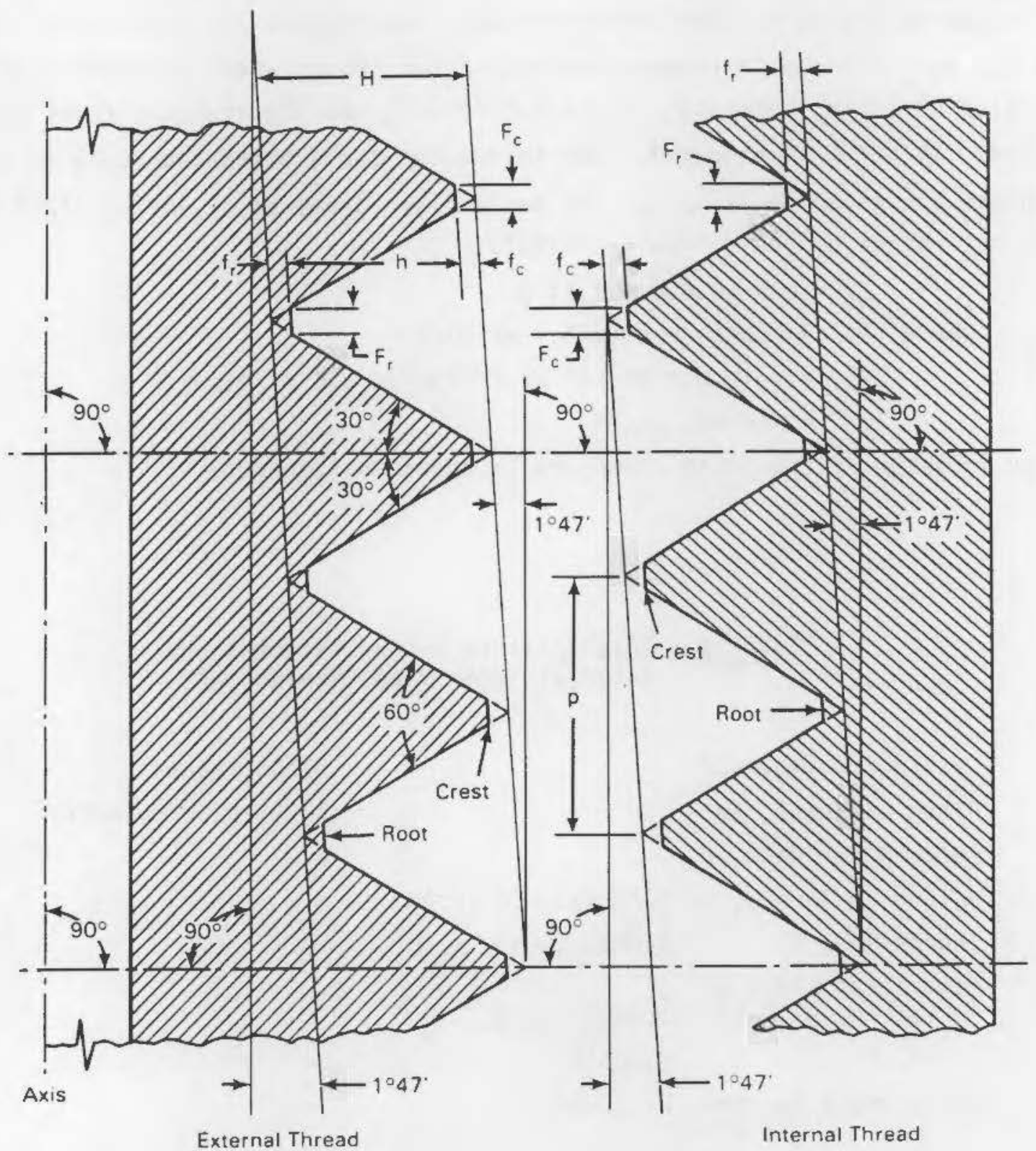

Notation

$\mathrm{H}=$ height of $60 \mathrm{deg}$. sharp $V$ thread

$\xi_{c}=$ depth of truncation at crest

$h=$ height of thread on product

$f_{1}=$ depth of truncation at root

$p=1 / n=$ pitch (measured parallel to axis)

$F_{c}=$ width of flat at crest

$n=$ number of threads per inch

$F_{1}=$ width of flat at root

FIGURE 3. Basic Form of USA Standard Taper Pipe Thread 


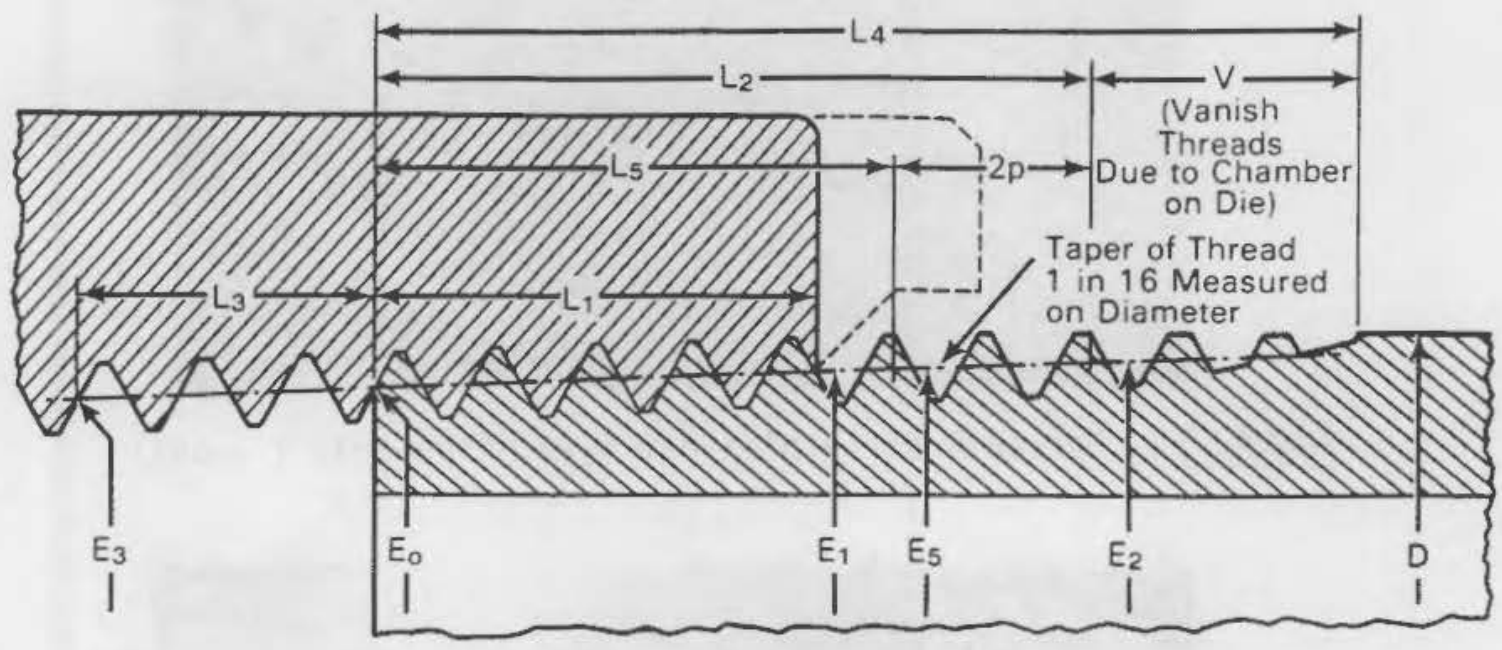

E. Pitch diameters D - O.D

$L$ - Various take up lengths

FIGURE 4. USA Standard Taper Pipe Thread Notation

Several new and old $2 R$ pipes and pipe plugs were optically gauged to determine conformance to the specifications. Profiles of these threads are shown in Figures $5,6,7,8$ and 9 . The measured values obtained from optically gauging the threads are given in Table 2.

Except for pipe body $Y$ (Figure 5 ), the thread profiles shown in Figure 6 , 7,8 and 9 appear uniform. Since the threads shown in figure 5 are new threads, it appears that they were cut with a badly worn die. The measured values listed in Table 2 show that the pipe threads for pipe $Y$ and the new plug A do not conform to the specifications. The other pipes and plugs listed in Table 2 are within the tolerance allowed except for the pitch diameter for the plugs and other minor deviations (truncations and flats). Using Equation (1), the thread pitches were calculated and compared to the measured pitch values. The calculated values for the thread pitches are shown in parentheses in Table 2. 


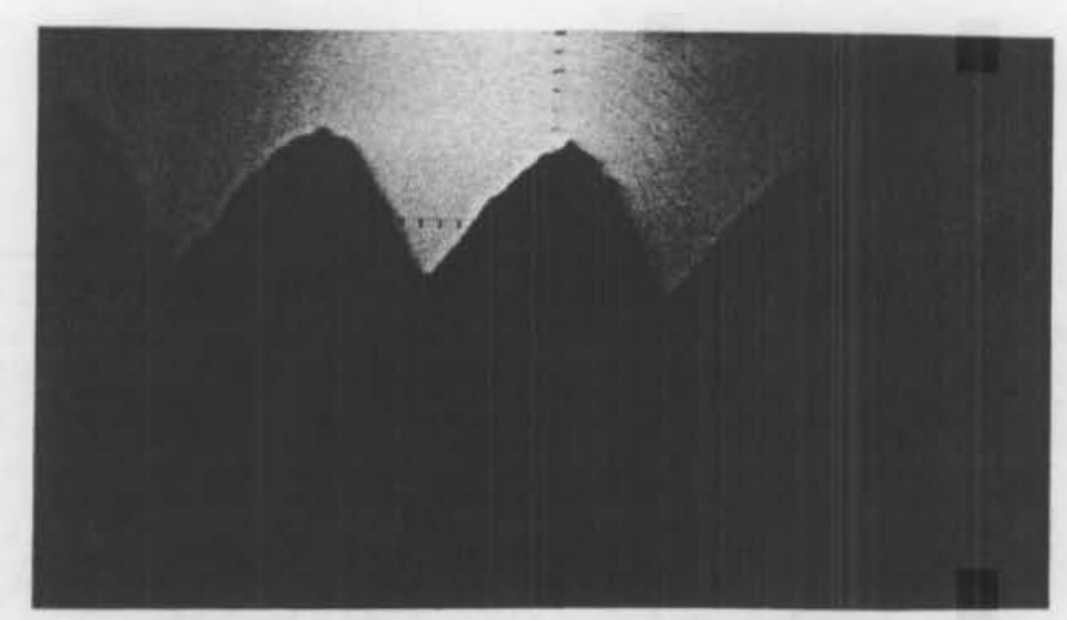

FIGURE 5. Thread Profile of a New 5-in. Pipe Body $Y(\sim 50 X)$

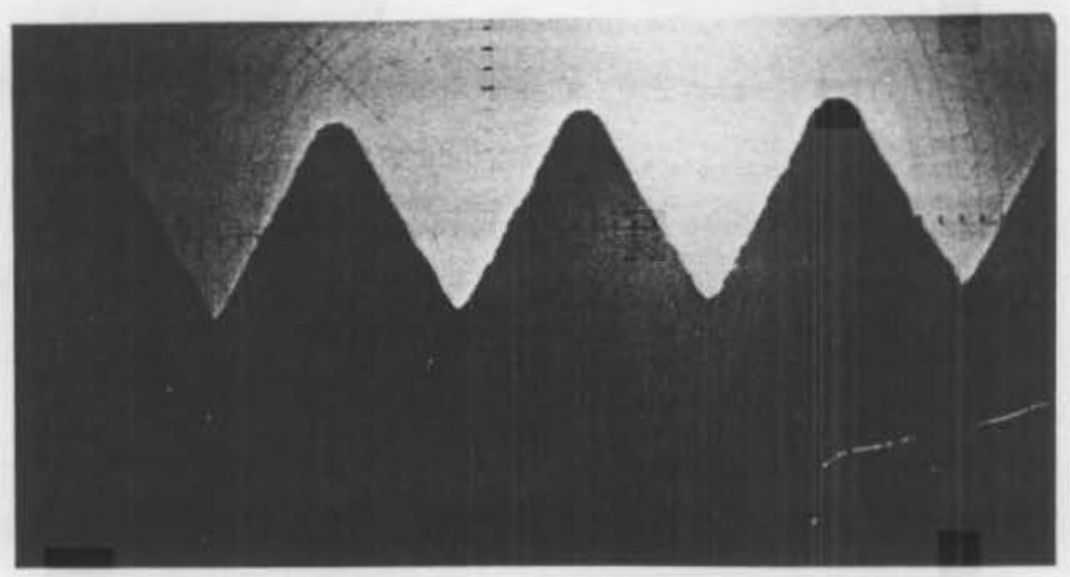

FIGURE 6. Thread Profile of a New 5-in. Pipe Body A ( 50X)

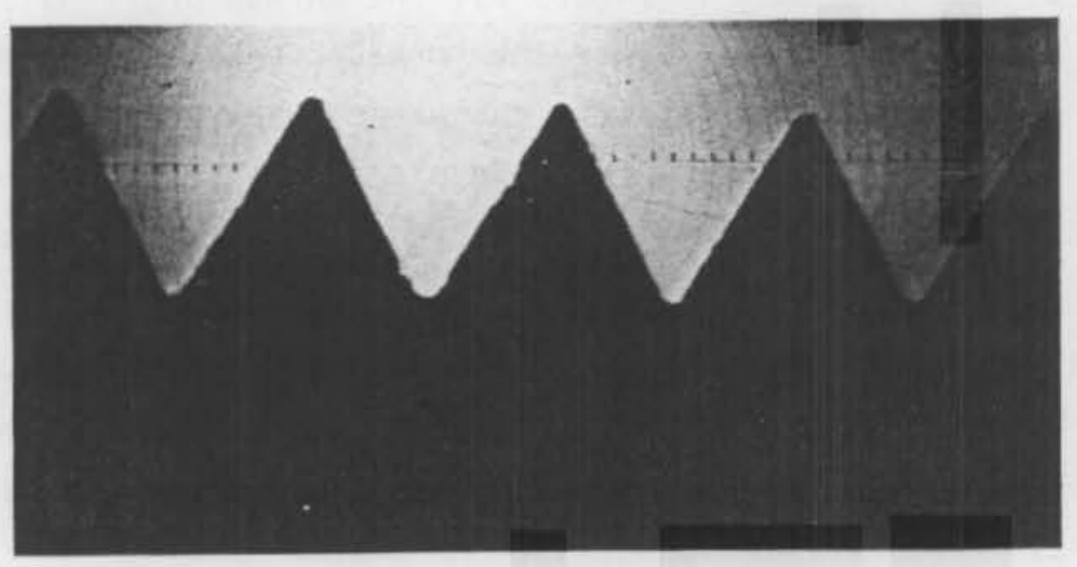

FIGURE 7. Thread Profile of an 0ld Pipe Body ( $50 x)$ 


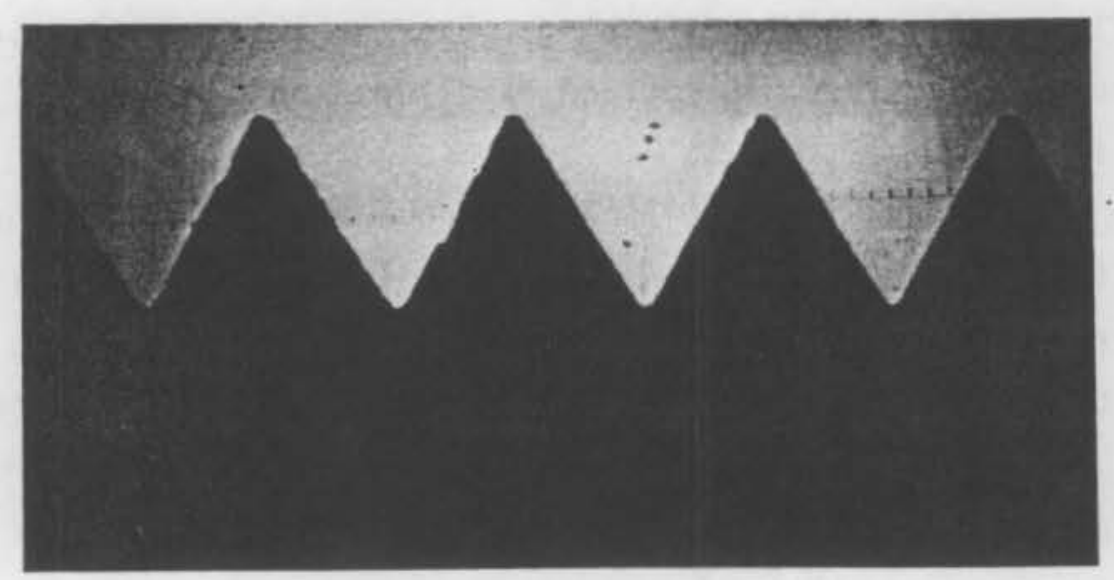

FIGURE 8. Thread Profile of a New Pipe Plug ( $50 x)$

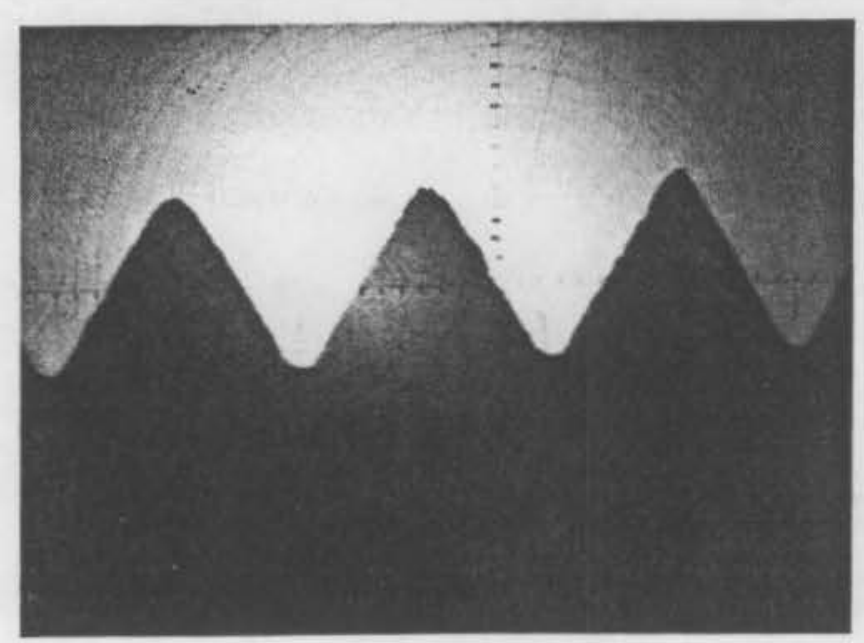

FIGURE 9. Thread Profile of an 01d Pipe Plug ( $50 x)$ 
$2 R$ vessels that have been used repeatedly sometimes develop worn threads if the threads are not properly lubricated. Figure 10 shows a thread profile of a used pipe body. The picture shows damage at the root of the thread.

Visual examination under low magnification $(3 x)$ is of value in determining thread condition. The thread profile shown in Figure 5 is also shown in Figure 11 at $3 X$ magnification. Even at low magnification, the threads show tool chatter and surface cracking. Other types of thread damage are shown in Figures 12 and 13.

Prior to leak testing, the threads were examined visually under low magnification $(3 x)$. If the threads appeared to be in good condition, the threads were luted with a luting compound. Some pressure tests, however, were made with threads in poor condition. The following luting compounds were tried:

- Teflon tape

- high-temperature silicone grease

- LA-CO T-0-T pipe joint compound

- LA-CO SLIC-TITE*

- G.E. Silicone Hi-Temp Gasket Material (GEC 56002).

TABLE 2. Measured Values for 5-Inch 2R Pipes and Plugs

\begin{tabular}{|c|c|c|c|c|c|c|c|c|}
\hline $\begin{array}{l}\text { Pipe } \\
\text { Designation }\end{array}$ & $\begin{array}{l}\text { Thresed } \\
\text { Hoight (h), } \\
\text { in. }\end{array}$ & $\begin{array}{l}\text { Thread } \\
\text { Angle }\end{array}$ & $\begin{array}{l}\text { Piteh } \\
\text { Angle }\end{array}$ & $\begin{array}{l}\text { Pitch } \\
\text { Dian. }\left(E_{0}\right) \text {, } \\
\text { in. }\end{array}$ & 0.0., & $\begin{array}{l}\text { Thread } \\
\text { in. Pitch in. }\end{array}$ & $\begin{array}{l}\text { Tryogeation } \\
\text { (f }\end{array}$ & $\begin{array}{l}\text { Equivalent figth) } \\
\text { of Flat, ( } F \\
\text { in. }\end{array}$ \\
\hline Nex Pipe Y & 0.079 & $63^{\circ} 0^{\circ}$ & 36. & 5.401 & 5.569 & 0.122 & $\begin{array}{l}t_{R}=0.0074 \\
r_{c}=0.0184\end{array}$ & $f_{f}=0.0094$ \\
\hline Nen Pipe A & 0.063 & $59^{\circ} 34^{\circ}$ & $1.49^{\circ}$ & 5.397 & 5.572 & $0.128(.127)$ & $\begin{array}{l}t_{R}=0.0068 \\
f_{c}=0.0070\end{array}$ & $\begin{array}{l}f_{R}=0.0074 \\
f_{c}=0.0074\end{array}$ \\
\hline 01d Pipe & 0.100 & $64^{\circ} 31^{\circ}$ & 1.23 & 5,401 & 5.582 & $0.128(.131)$ & $\begin{array}{l}f_{p}=0.006 \\
f_{c}=0.005\end{array}$ & $\begin{array}{l}F_{g}=0.010 \\
f_{c}=0.007\end{array}$ \\
\hline 01d Plu & 0.093 & $60^{\circ} 10^{\circ}$ & $10^{\circ} 20^{\circ}$ & 5.307 & - & 0.122 & $\begin{array}{l}r_{R}=0.0133 \\
f_{c}=0.0002\end{array}$ & $\begin{array}{l}f_{R}=0.016 \\
f_{c}=0.053\end{array}$ \\
\hline Wen Plus a & 0.093 & $60^{\circ}$ & $9^{\circ} 45$ & 5.307 & -. & 0.123 & $f_{R}=0.0046$ & $\begin{array}{l}F_{R}=0.0048 \\
f_{c}=0.0150\end{array}$ \\
\hline
\end{tabular}

(a) $F_{R}$ - Truncation at root of thread (see Figure 3)

(b) $F_{R}$ - Width of fiat at root

Teflon is a registered trademark of E.I. Dupont deNemours.

- LA-CO T-0-T and LA-CO SLIC-TITE are registered trademarks of Lake Chemical Co.

- GEC 560002 is a registered trademark of the General Electric Co. 


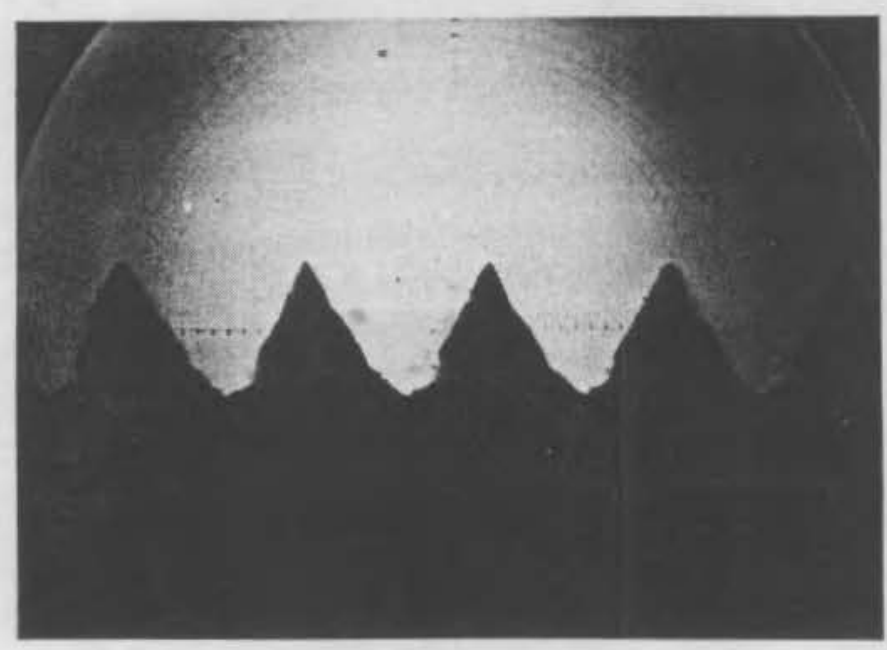

FIGURE 10. Thread Profile of a Pipe with Thread Damage ( 50x)

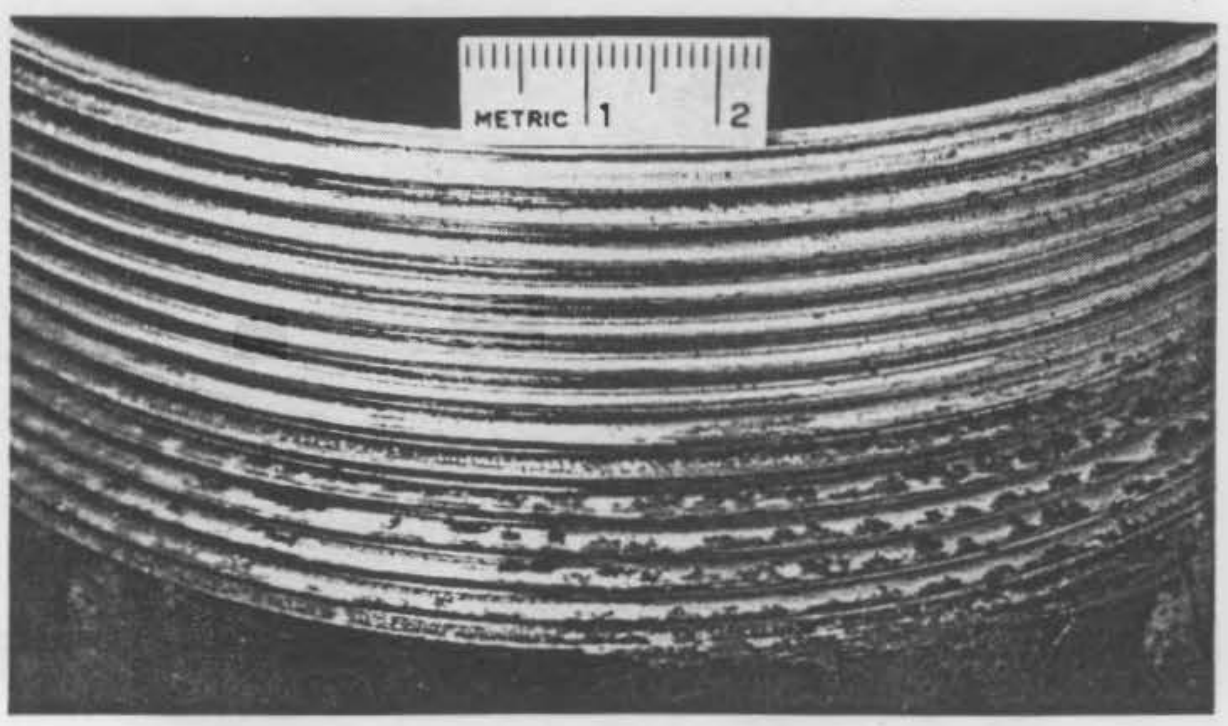

FIGURE 11. Low Magnification (3X) Photograph of Pipe Body $Y$ 


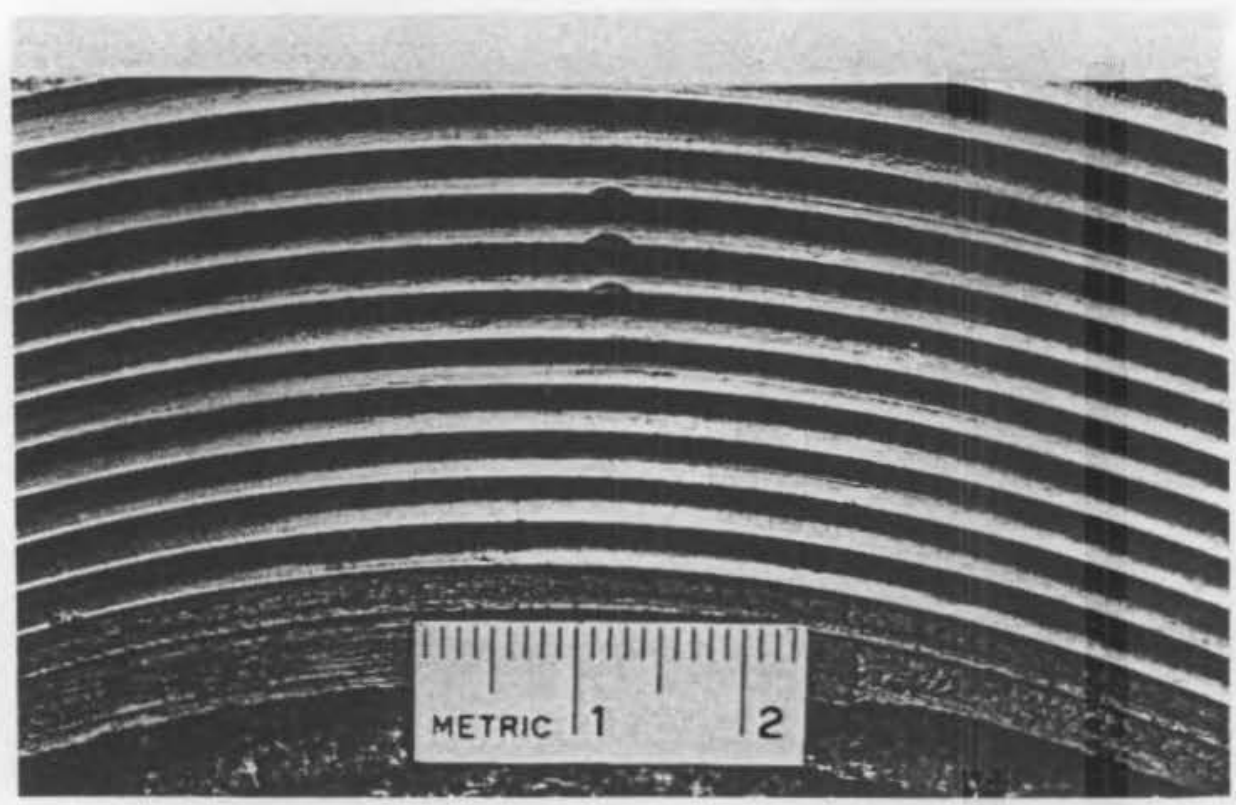

FIGURE 12. Minor Thread Damage on Pipe Cap

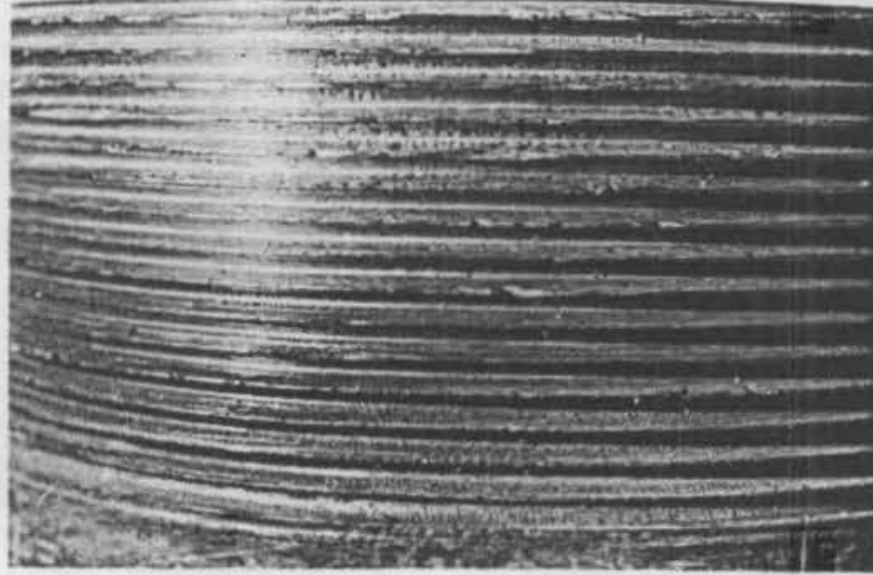

FIGURE 13. Thread Damage on 01d Pipe Body 
The Teflon tape was the standard material commonly used to tape pipe threads. At least three layers of tape were usually wrapped over the threads. The silicone grease was a high-temperature vacuum grease, with a temperature range of $5^{\circ} \mathrm{F}$ to $480^{\circ} \mathrm{F}$.

The LA-CO T-0-T pipe compound is a common pipe compound used to make up water and steam lines. The material contains silicone for lubrication. The temperature range listed by the manufacturer (Lake Chemical $\mathrm{Co}_{\text {.) }}$ is from $-20^{\circ} \mathrm{F}$ to $200^{\circ} \mathrm{F}$.

The LA-CO SLIC-TITE paste luting compound is the compound applied to the $2 R$ vessels by $F B F$ Incorporated, the principal supplier of the $6 M$ containers. The pipe compound has Teflon suspended in a neutral vehicle. The compound can be used when temperatures range from $-50^{\circ} \mathrm{F}$ to $500^{\circ} \mathrm{F}$.

The silicone rubber is a high-performance silicone sealant. The material used in the testing program was a high-temperature variety manufactured by General Electric. The temperature range listed for the material is from $-80^{\circ} \mathrm{F}$ to $500^{\circ} \mathrm{F}$.

To compare the sealing characteristics of the various compounds, a series of pipe assemblies was used. All the compounds listed were usually applied to each assembly tested so that a comparison could be made between them. The procedure used for a single pipe assembiy was as follows:

1. Clean threads thoroughly.

2. Examine threads using magnifying glass.

3. Apply luting compound to threads of both cap, plug or pipe.

4. Screw cap or plug onto pipe and torque to $100 \mathrm{ft}-1 \mathrm{~b}$.

5. Pressure test assembly at 15 psig under water. If leakage is detected, tighten assembly in 50 or $100 \mathrm{ft}-1 \mathrm{~b}$ increments until assembly is leak tight or $400 \mathrm{ft}-\mathrm{lb}$ is reached.

6. Repeat above steps using a different luting compound. 
The pipe threads that had been luted with the pipe thread compounds and greases were successfully cleaned with trichloroethylene. After degreasing the threads, they were blown dry by compressed air. Removal of the silicone rubber was more difficult. The threads were soaked in xylene for 12 to 14 hours, which caused the rubber to soften and swell. After soaking, the rubber was stripped off by using a wire brush and applying the trichloroethylene while brushing.

Leak tests with the pipe assemblies were also conducted at higher temperatures and pressures. Pipe assemblies that had been luted with the silicone rubber compound were pressurized to $100 \mathrm{psig}$ and heated to $320^{\circ} \mathrm{F}$.

The apparatus used for leak testing the $2 R$ vessels are shown in Figures 14, 15 and 16. The vacuum bubble tester (Figure 14) was limited to a pressure difference of one atmosphere. The gas pressure units shown in Figures 15 and 16 were used to pressurize the $2 R$ vessels to 100 psig. Silicone oil was used in the bath (Figure 16) when the $2 R$ vessel was heated to $320^{\circ} \mathrm{F}$. The $2 R$ vessels were also heated in furnaces to $300^{\circ} \mathrm{F}$ to test the sealing quality of the various luting compounds.

In order to apply a known torque force to a cap or plug, special fixtures were fabricated (Figures 17 and 18). Also, a 1-15/16-in. bolt head was welded to a cap so that a 1-15/16-in. socket could be used to tighten the cap. The torque wrench used was calibrated to a $\pm 2 \%$ accuracy.

\section{FUOD PACK CANS}

The metal cans that were tested were common food pack cans used to package and preserve food. The various sizes of cans tested are shown in Figure 19. The cans conform to a Federal specification, PPP-C-960. The specifications classify the cans as Type I Class 3 (Packer's Can). A Type I Class 3 can has a round, open top with compound-lined double-seamed ends. The double seam consists of five thicknesses of plate interlocked or folded and pressed firmly together (Figure 20). At the junction of the side seam with the lid, there are seven thicknesses of plate. The side seam of the can is crimped as shown in Figure 21. This seam is soldered or welded after crimping. The food pack cans tested were made from tin plate ranging in thickness from 0.008 inch to 0.010 inch. Tin plate is made from carbon steel sheets coated with tin. The tin plate must conform to the specification 


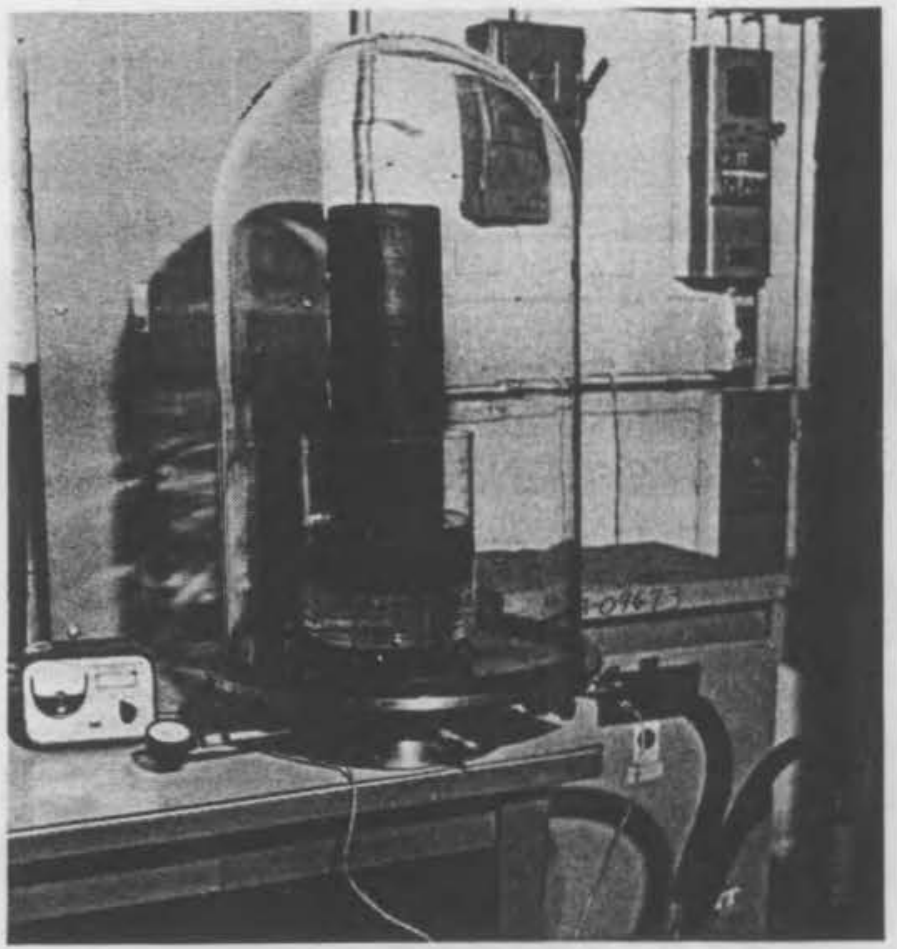

FIGURE 14. Apparatus Used for Vacuum Bubble Testing $2 R$ Vessels

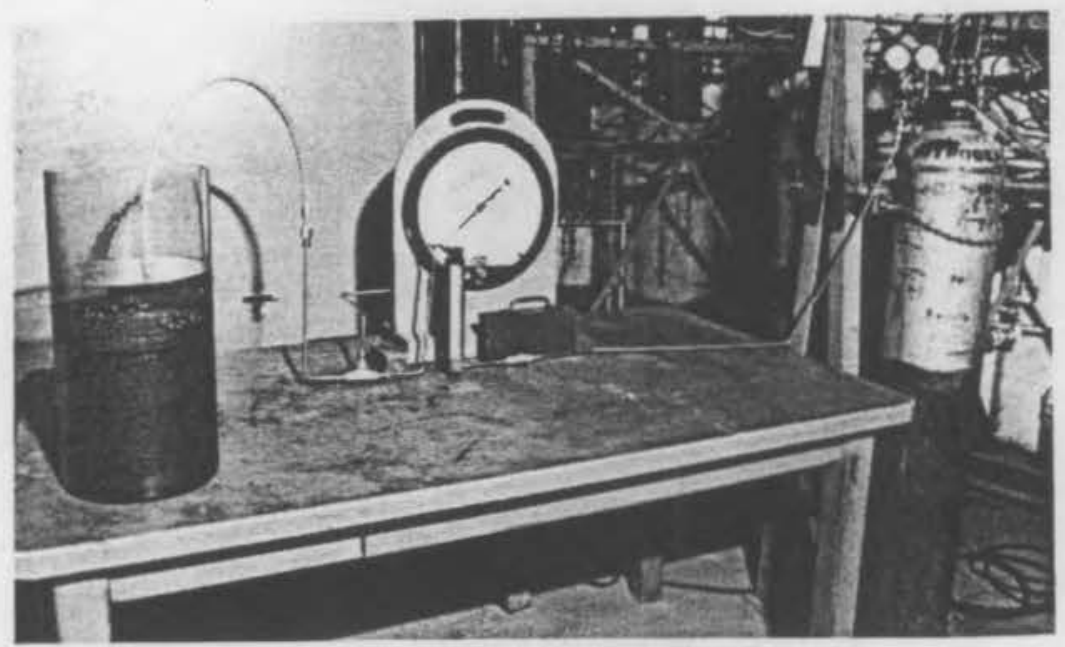

FIGURE 15. Apparatus Used for Bubble Testing 2R Vessels at Elevated Pressures 


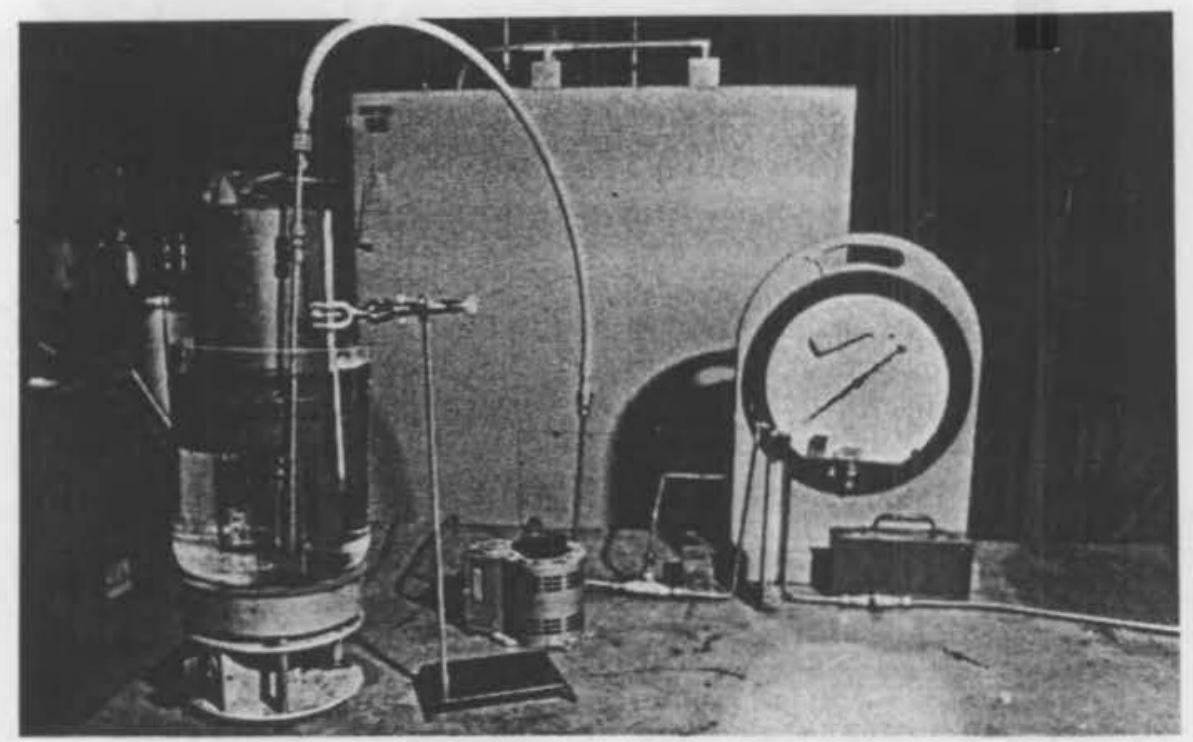

FIGURE 16. Apparatus Used for Bubble Testing $2 R$ Vessels at Elevated Temperature and Pressure

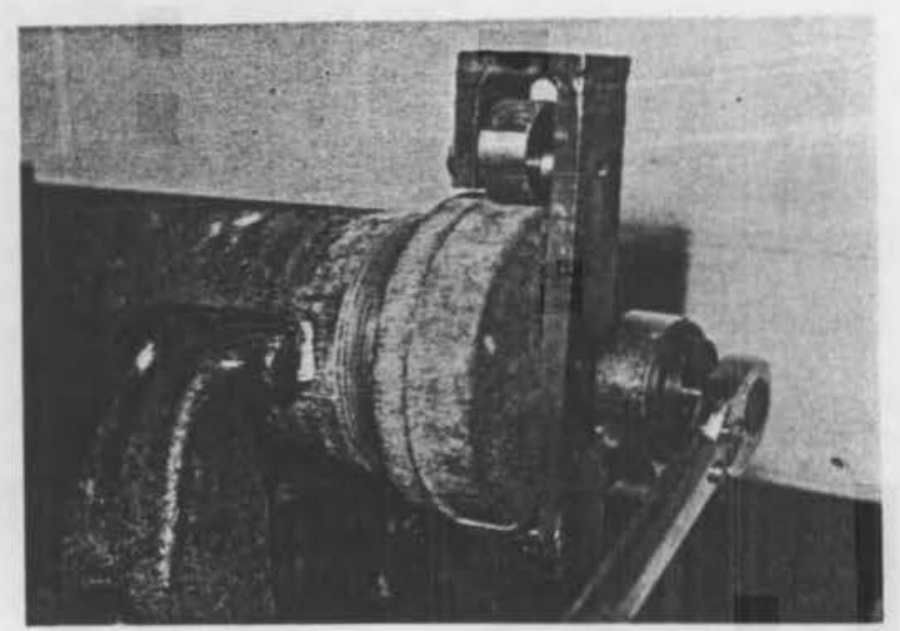

FIGURE 17. Pipe Cap Fixture Used to Torque Pipe Caps on Pipe Bodies 


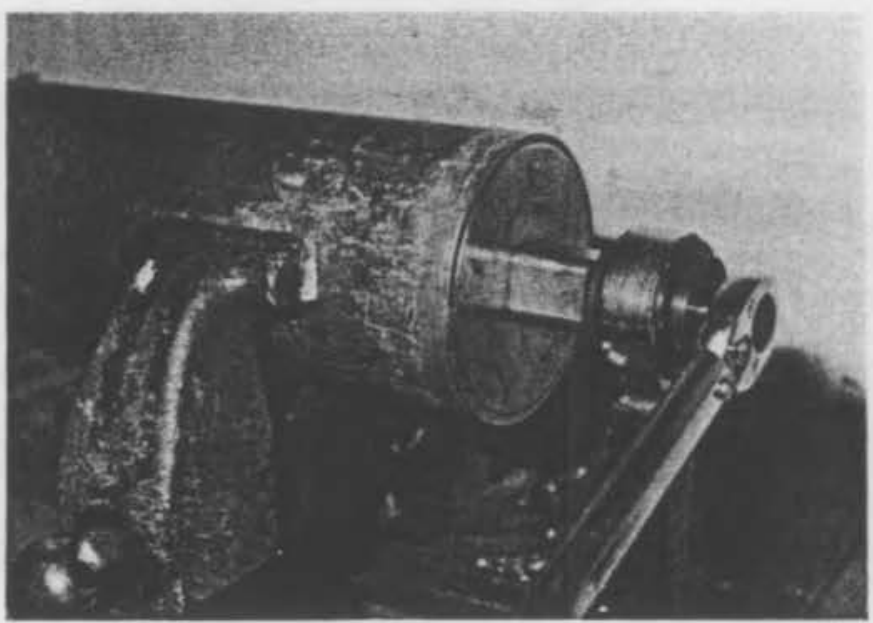

FIGURE 18. Pipe Plug Fixture Used to Torque Pipe Plugs on Pipe Tubes

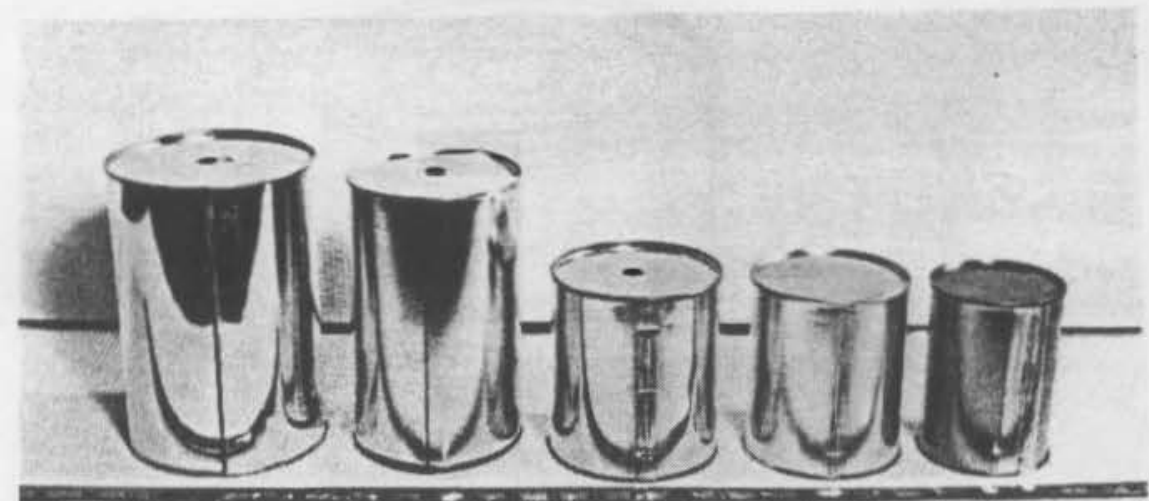

FIGURE 19. Various Size Cans used in Pressure Tests 


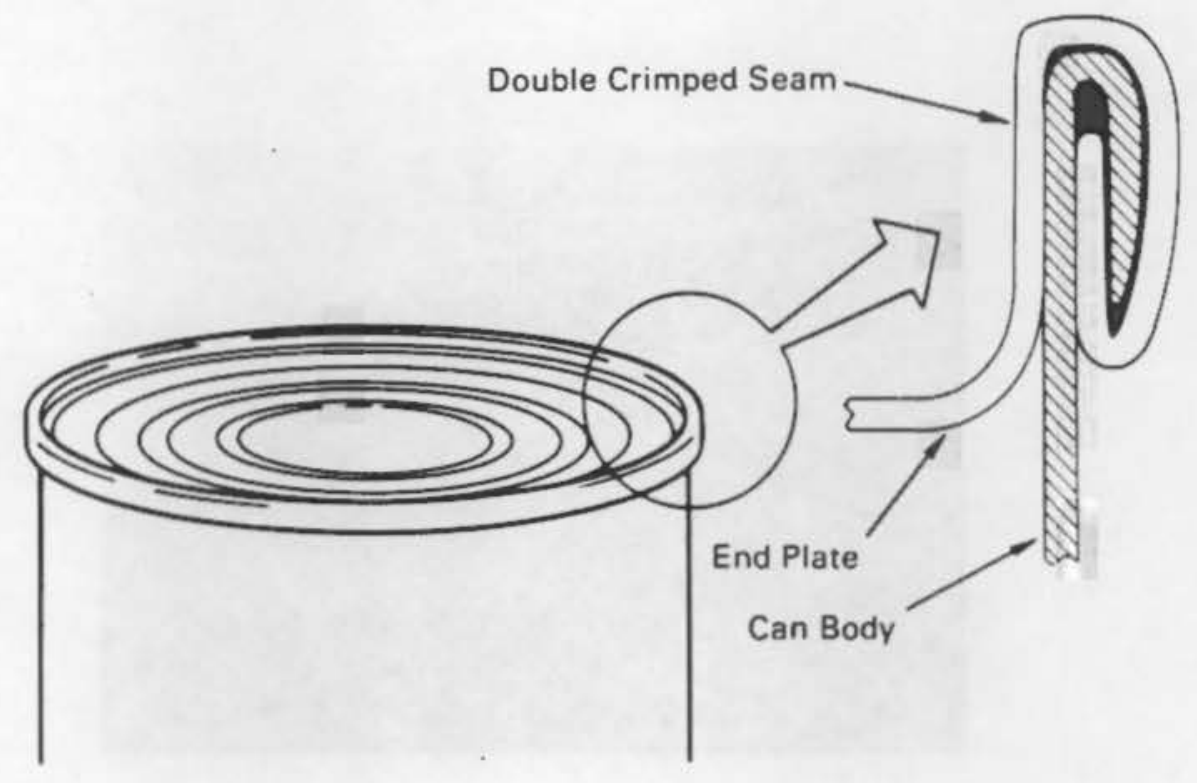

FIGURE 20. Cross Section of a Crimp-Sealed Lid on a Food Pack Can
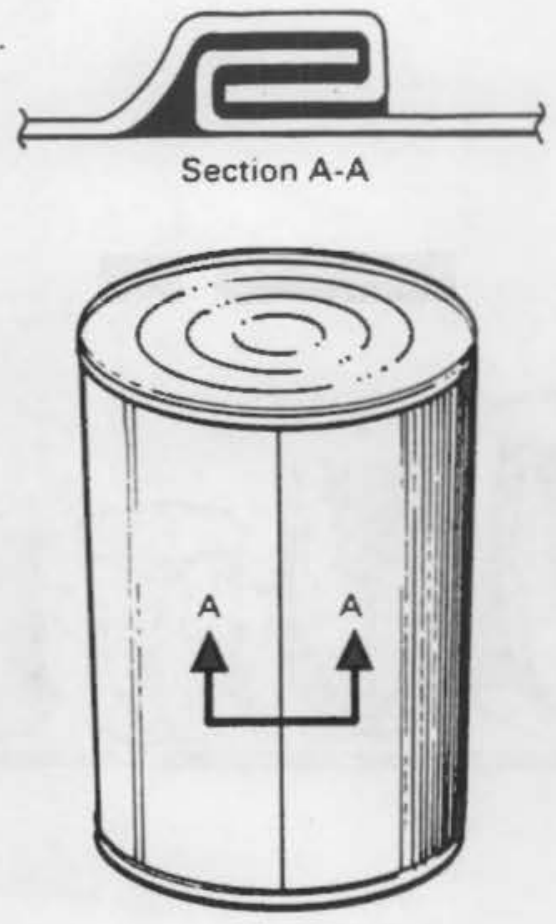

FIGURE 21. Cross Section of the Side Seam of a Food Pack Can 
$\mathrm{Q}-\mathrm{T}-425$. The tin coating is usually very thin ranging in thickness from $0.00015 \mathrm{in}$. to $0.000060 \mathrm{in}$. In addition to the tin coating, these cans are usually coated with different kinds of coatings or enamel (epoxy) to protect the surface from certain types of foods that may be packaged.

The specification PPP-C-96D states that the seaming compounds used in the lids and side seams of the can shall comply with commercial standards. The material commonly used is a butyl rubber-type material that is applied under pressure to the lids. Cans that require hermetic seals must be tested for leakage. The specification requires that the cans be pressurized to 3 psig for 30 minutes without evidence of leakage. The leak test method prescribed by the regulation is method 5009 of Federal Standard No. 101. This test amounts to a hot water bubble test that will provide the 3 psig pressure required. Leakage is defined by the recurring formation of bubbles in the bath from any surface on the can in the time interval specified.

In order to obtain hermetically sealed cans, a proper crimp seal must be made. Several things can influence the type of seals that are obtained. Among these are:

- condition of the sealing compound (gasket)

- condition of the can body

- condition of the flange (before crimping)

- proper setup of the can sealer.

The specifics on obtaining good seals are discussed in Appendices $B$ and $C$.

Sealing compounds such as glyptal enamel and silicone rubber were used to seal cans that leaked. The sealing compounds were applied to the seams after they had been crimped (Figure 22). Usually two applications of the sealant were required to obtain hermetic seals. The sealant was allowed to dry 12 to 14 hours between applications and testing.

The leak testing performed on the metal cans was more severe than required by the federal specification. The sealed cans were vacuum bubble tested and gas pressure tested. The setup for the vacuum bubble tester and gas pressure tester was similar to the one used to leak test the $2 R$ vessels (Figures 23 and 24).

In the gas pressure unit, the leak rate was measured by in-line rotometers. Two sizes of rotometers were used. One rotometer was capable of sensing flow rates between $0.4 \mathrm{std}$. cc/min to $120 \mathrm{cc} / \mathrm{min}$ and the other could 
measure flow rates between $100 \mathrm{cc} / \mathrm{min}$ to $5500 \mathrm{cc} / \mathrm{min}$ at a $10 \mathrm{psig}$ pressure differential. The rotometers were calibrated using a bubbler pipet.

An absolute leak rate cannot be obtained with the vacuum bubble test. However, the sensitivity of this test (King 1965) has been determined by preparing a number of calibrated leaks, measuring the hole sizes microscopically and measuring the leak rates. Leak rates as small as $\sim 4 \times 10^{-6}$ atm cc/sec can be detected by using good lighting and low power magnification (3x) to inspect the part being leak checked.

In order to obtain quantitative leak rates below $10^{-5} \mathrm{cc} / \mathrm{sec}$, metal cans were sealed containing a helium atmosphere. The cans were placed in a vacuum chamber that was connected directly to a helium leak detector. Calibrated leak sources were used to determine the helium leak rate of the metal cans.

\section{IMPACT AND HEATING TESTS}

Impact and heating tests were performed on loaded 30-gallon $6 \mathrm{M}$ containers. Different packaging arrangements of the metal cans inside the $2 R$ vessel were tested. In all the arrangements tested, two columns of cans were stacked inside the $2 R$ container. The difference in the packaging arrangements was the method used to protect the metal cans inside the $2 R$ vessel. Rubberized horsehair and empty metal cans were used as impact limiters. The packaging configurations are shown in Figures 25 and 26.

The inner food pack cans $(4-1 / 16-i n$. D $\times 4-11 / 16-i n . h)$ shown in Figures 25 and 26 were loaded with either sand or sand and lead shot. When sand alone was used, the amount of sand loaded into a single $4-1 / 16-i n$. D $\times 4-11 / 16-i n$. $h$ can was between 1100 to $1200 \mathrm{~g}$. When sand and lead shot were added to the cans, the cans were loaded to approximately $2.3 \mathrm{~kg}$ each. The sand and shot provided the ballast needed to simulate loadings of radioactive material such as $\mathrm{UO}_{2}$ and $\mathrm{PuO}_{2}$ powders. The cans containing the sand were either vacuum bubble tested or pressure tested and were gas tight $\left(<10^{-5} \mathrm{cc} / \mathrm{min}\right)$ prior to the test. The cans containing the sand and shot were placed in the larger cans 4-1/4-in. D $\times$ 7-in. $h$ with either rubberized horsehair or an empty metal can filling the void space. The cans were then stacked inside the $2 R$ vessel as shown in Figures 25 and 26. 


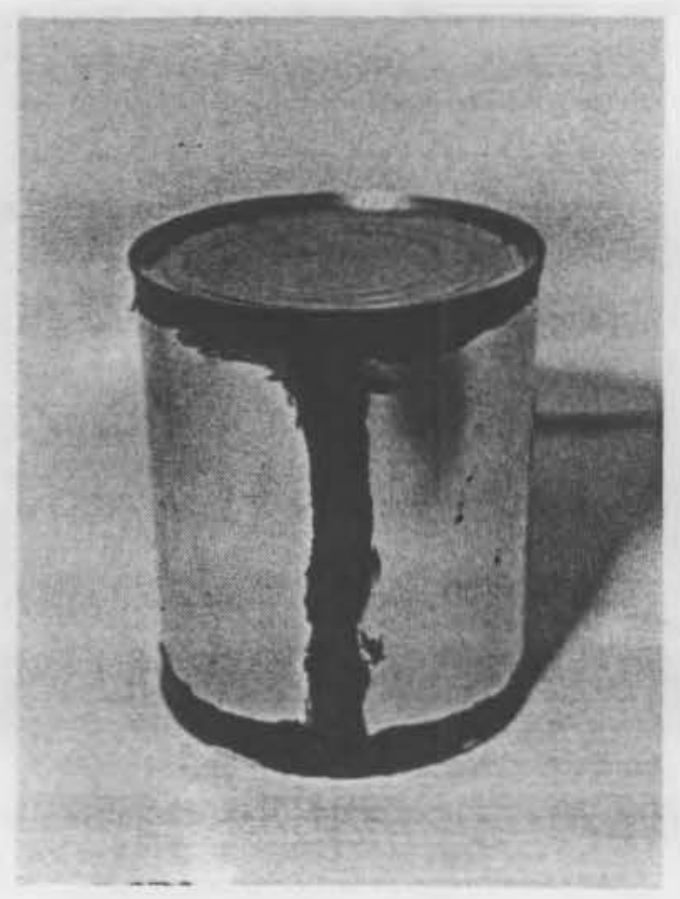

FIGURE 22. Seams of Food Pack Cans Coated with Silicone Rubber Compound

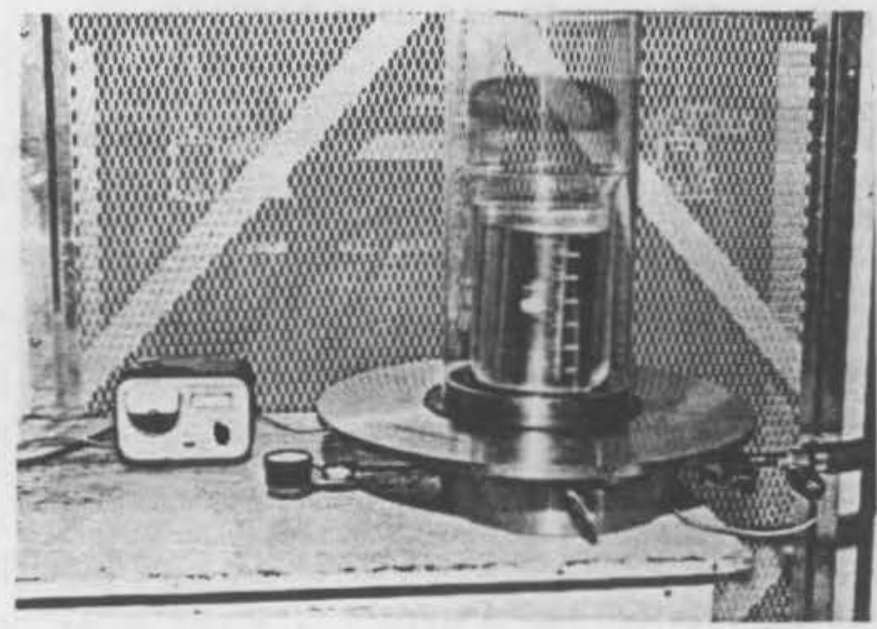

FIGURE 23. Apparatus Used for Bubble Testing Crimp-Sealed Cans 


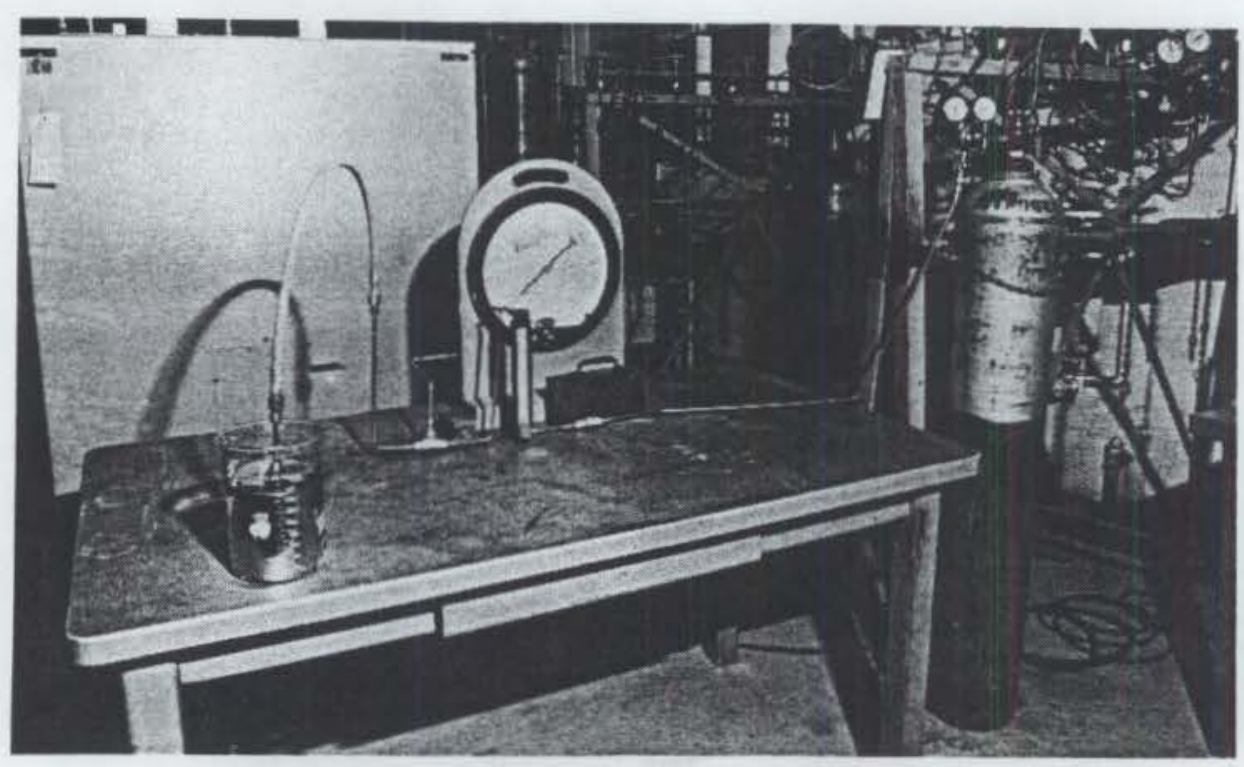

FIGURE 24. Apparatus Used to Bubble Test CrimpSealed Cans at Elevated Pressures

The metal spacers shown (Figure 26) were used in tests after the horsehair and metal lid spacers were tested. The spacer plates were machined so that the cans would not shift horizontally during impact. By eliminating the horizontal movement, the impact forces would be transmitted to the side walls rather than the lids of the cans. The column of cans along with the spacer cans were stacked in such a manner that the column was compressed when the plug or cap was screwed onto the pipe body.

After loading, the $2 R$ vessels were shaken and no rattling could be detected. The threads of the $2 R$ vessels were luted either with hightemperature silicone grease, LA-CO SLIC TITE paste or silicone rubber. The specification for the $6 M$ container $\{49$ CFR $178.104(e)\}$ requires bearing plates to be used on the top and bottom of the $2 R$ vessel inside the $6 M$ drum when the container weight exceeds 480 pounds. The 30 -gallon size $6 \mathrm{M}$ containers do not require bearing plates but the larger containers do, so the effect of the bearing plates on impact loading needed to be determined. For one of the impact tests a $10-i n . \times 10-i n . \times 1-1 / 8-i n$. thick plywood plate was placed on top of the $2 R$ vessel inside the $6 M$ drum. All the other drop tests were done with the $2 R$ in contact with the celotex packaging material. 

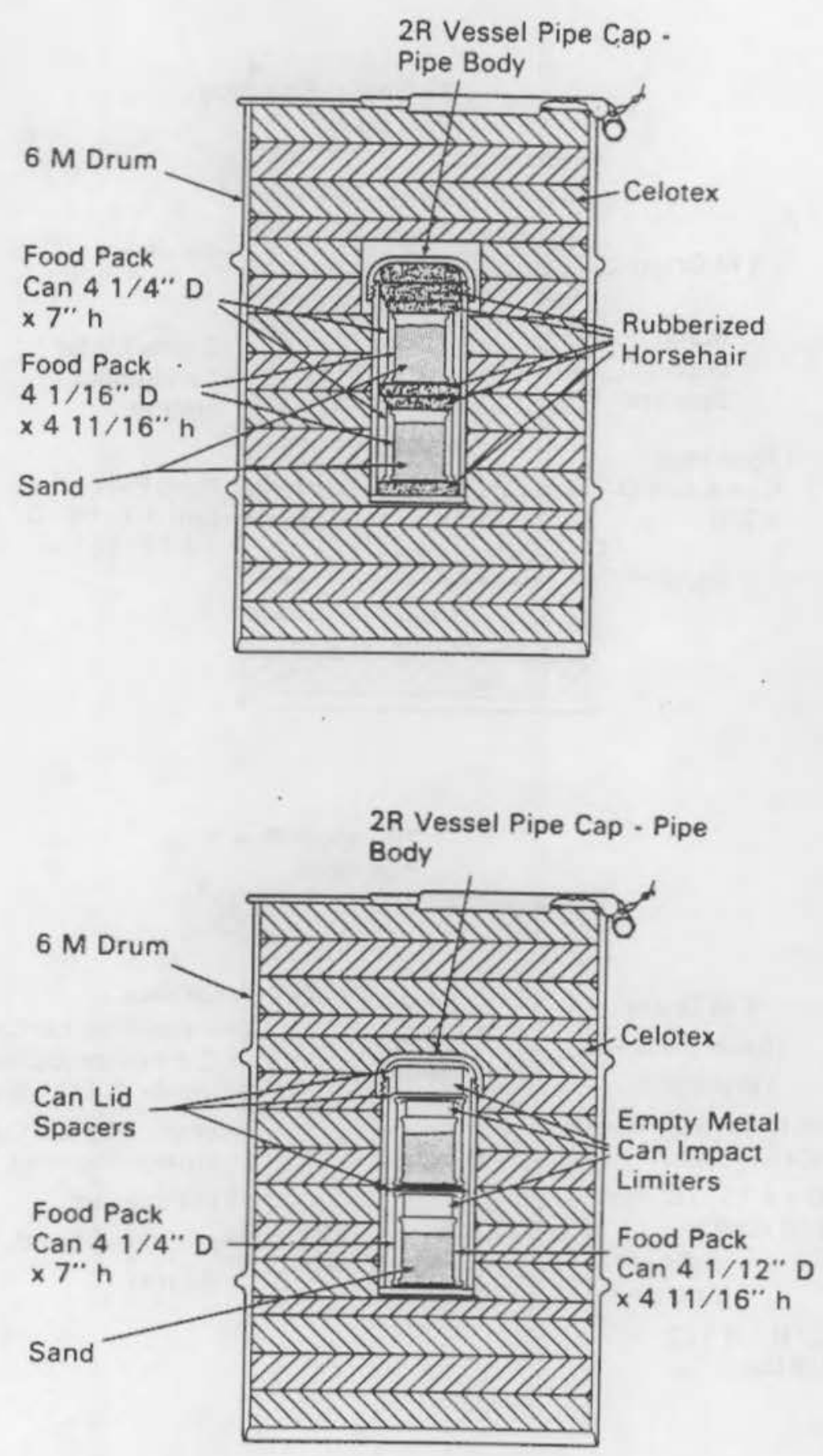

FIGURE 25. Cross Section of DOT-6M Containers Showing Packaging Configurations Used to Protect the Metal Cans During Impact Testing 

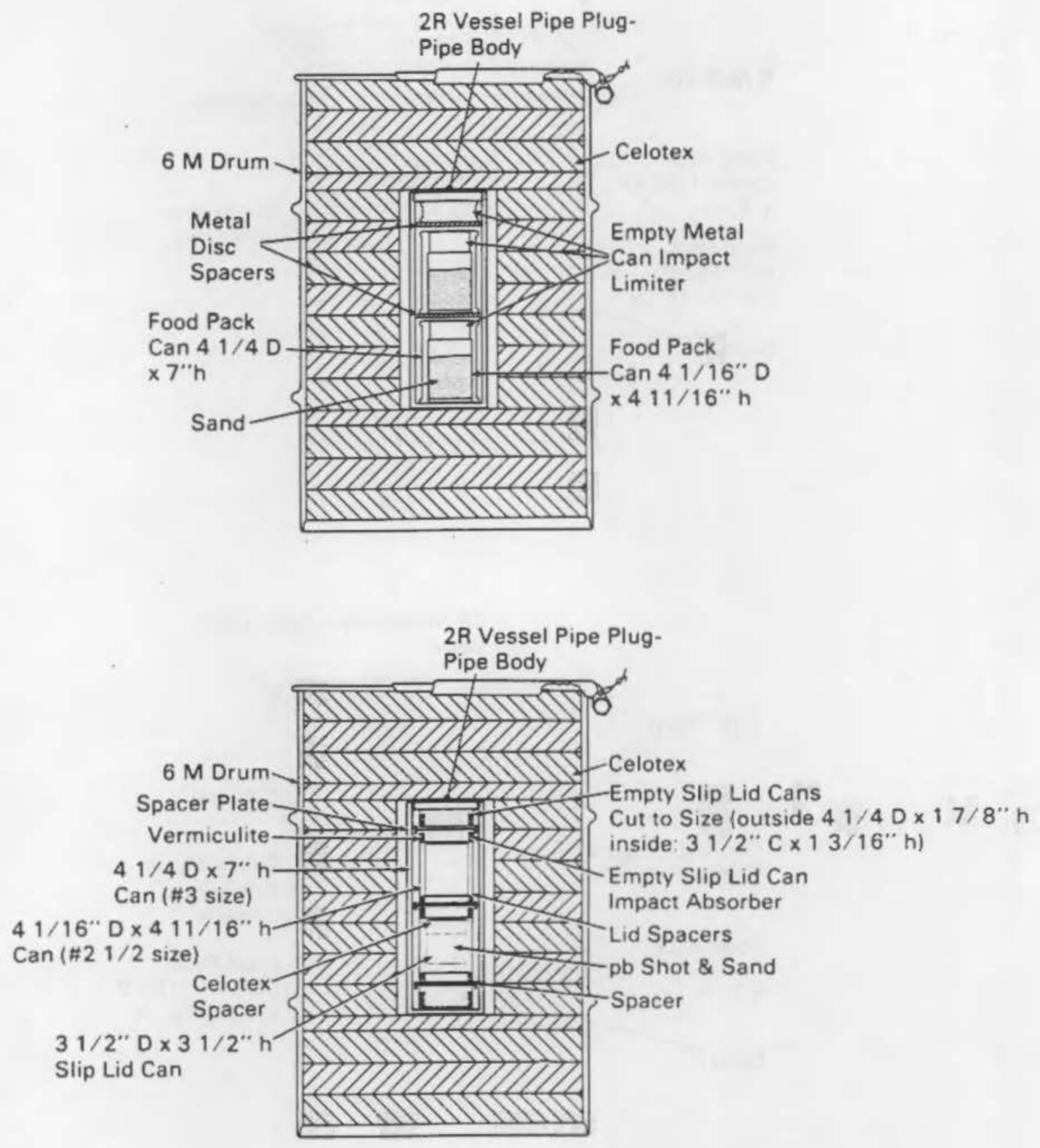

FIGURE 26. Cross Section of DOT-6M Container Showing Packaging Configuration Used to Protect the Metal Cans During Impact Testing 
After loading the $2 R$ vessel into the $6 M$ drum, the drums were dropped 30 feet (Figure 27) onto a concrete pad embedded with a steel plate. The drums were dropped end on because it was reported (Blankenship 1980) that the cans received the most damage when the drums were dropped in that position.

After impact, the $2 R$ vessel was pressure tested to determine leakage. The $2 R$ vessel was then placed in a furance, heated to $300^{\circ} \mathrm{F}$, held at $300^{\circ} \mathrm{F}$ for at least one hour, and then removed from the furnace. During the heating and soaking, the pressure inside the $2 R$ vessel was monitored. The $2 R$ vessel was also vented during some of the heating tests so that the differential pressure $(\triangle P$ ) inside the cans would be greater. The metal cans were examined after the impact and heating tests, and were either vacuum bubble tested or pressure tested.

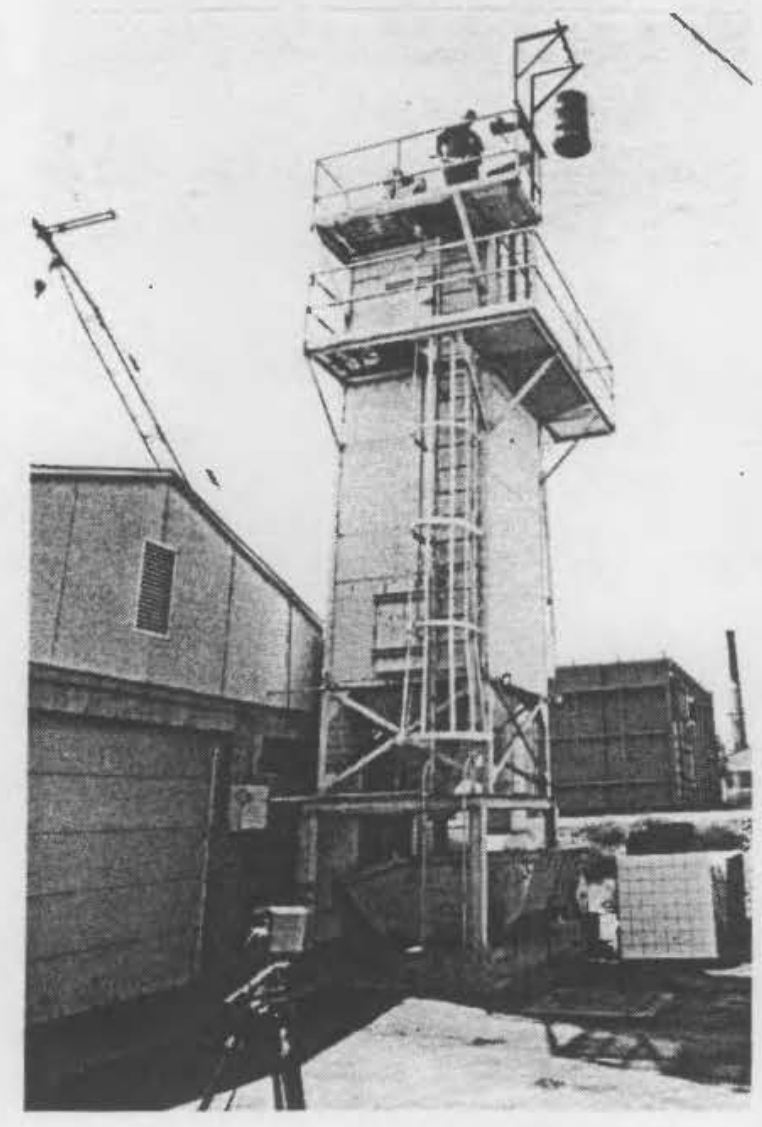

FIGURE 27. Drop Test Facility for Impact Testing of 6M Containers 


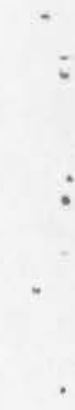




\section{RESULTS AND DISCUSSION}

This section discusses the results of leak testing $2 R$ vessels and metal cans. The effect of impact and heating tests on the leak rate of the $2 R$ vessels and the metal cans is also discussed.

\section{R INNER CONTAINMENT VESSELS}

Four pipe cap-pipe body and two pipe-plug pipe body assemblies were tested. A comparison was made between new and used pipe assemblies. The results of the leak tests are given in Table 3 . Some correlation between the leak rate and the thread specifications given in Table 2 was attempted. It was assumed that the pipe bodies and plugs within specifications would seal at lower torques than those that were out of specification. However, when the pipe assemblies were leak tested, no conclusive correlation could be made based on the data in Table 2 .

The correlation between thread specification and sealing ability held up no better with the pipe-plug pipe tube assemblies. Both the new and the old plugs were not within specifications; however, when the A plug was screwed into the pipe tube, the fit was quite loose as compared to the make up of the old plug in the pipe tube. It was possible to seal (air tight $<10^{-5} \mathrm{cc} / \mathrm{sec}$ ) the used plug assembly with all of the pipe compounds tried. But no seals were obtained with the A plug assembly with any of the compounds tried, except the silicon rubber compound.

The fit between the mating parts determines how well a pipe assembly seals. A condition might prevail, although remote, where a cap or plug that was out of specification might compensate for a pipe body that was out of specification, the result being that when the two were fastened together they might fit better than two parts that were within the specifications. Unfortunately, pipe ring and plug gauges were not available to gauge both the inside and outside threads. The optical comparator that was used could only measure outside threads. 
TABLE 3. Leak Test Data for Pipe Cap, Pipe Plug, Pipe Body Assemblies

\begin{tabular}{|c|c|c|c|c|c|c|c|c|}
\hline $\begin{array}{c}\text { Pipe } \\
\text { Ansecoly }\end{array}$ & Condition & Test No. & $\begin{array}{l}\text { Cotical } \\
\text { Profile }\end{array}$ & $\begin{array}{l}\text { Lut ing } \\
\text { Compound }\end{array}$ & $\begin{array}{l}\text { Tightening } \\
\text { Tarque, } \mathrm{ft}-\mathrm{lba} \\
\end{array}$ & $\begin{array}{c}\text { Pressure } \\
\text { psig }\end{array}$ & $\begin{array}{c}\text { Leak } \\
\text { Rate, } \mathrm{cc} / \mathrm{sec} \\
\end{array}$ & Comonts \\
\hline$\underset{n A^{n}}{\operatorname{Pipe}}$ & New & 7 & Fig. 5 & $\begin{array}{l}L A-C D \\
T-Q-T\end{array}$ & 200 & 10 & $<2$ & $\begin{array}{l}\text { Used difforent pipe } \\
\text { cap. }\end{array}$ \\
\hline Pipe Cap & New & 8 & Fig. 5 & $\begin{array}{l}L A-C O \\
T=O-T\end{array}$ & 400 & 11 & Leaks & $\begin{array}{l}\text { Same pipe cap as in } \\
\text { test } 7 \text {. }\end{array}$ \\
\hline Pipe Cap & New & 9 & Fig. 5 & $\begin{array}{l}\text { LA-CO } \\
\text { S1 ic-Tito }\end{array}$ & 200 & 100 & to leaks & \\
\hline$P_{n A^{n}}$ Cap & New & 10 & Fig. 5 & $\begin{array}{l}\text { LA-CO } \\
\text { Slic-Tito }\end{array}$ & 100 & 20 & Leelood & \\
\hline Pipe Cap & Now & 11 & Fig. 5 & $\begin{array}{l}\text { LA-CO } \\
\text { SHIC-Tite }\end{array}$ & 200 & 100 & To leaks & \\
\hline${ }_{\text {Pipe }}^{\text {Capp }}$ & New & 12 & Fig. 5 & $\begin{array}{l}\text { LA-CO } \\
\text { Slic-Tite }\end{array}$ & 200 & 100 & to leaks & $\begin{array}{l}\text { Heated to } 300^{\circ} \mathrm{F} \text { in } \\
\text { stlicon bath and } \\
\text { pressurized. Ueed new } \\
\text { pipe compound. }\end{array}$ \\
\hline Pipe Cap & $\begin{array}{l}\text { Slight ly } \\
\text { Ueed }\end{array}$ & 1 & -- & $\begin{array}{l}\text { Silicon } \\
\text { Grease }\end{array}$ & 300 & 75 & No leaks & - \\
\hline Pipe Cap & $\begin{array}{l}\text { Slight ly } \\
\text { Lbed }\end{array}$ & 2 & - & $\begin{array}{l}\text { Sillicon } \\
\text { Grease }\end{array}$ & 300 & 15 & $\sim 0.2$ & $\begin{array}{l}\text { Masembly torqued to } \\
\text { yo ft-1ba and loosened } \\
12 \mathrm{tinse} \text {. }\end{array}$ \\
\hline Pipo Cap & $\begin{array}{l}\text { Slightly } \\
\text { Ueed }\end{array}$ & 3 & - & $\begin{array}{l}\text { Silicon } \\
\text { Grease }\end{array}$ & 100 & 15 & mo & \\
\hline Pipe Cap & $\begin{array}{l}\text { Slight ly } \\
\text { Uesed }\end{array}$ & 4 & - & $\begin{array}{l}\text { Silicon } \\
\text { Grease }\end{array}$ & 200 & 15 & $\sim 7$ & \\
\hline Pipe Cap & $\begin{array}{l}\text { Slightly } \\
\text { Uned }\end{array}$ & s & Fig. 9 & $\begin{array}{l}\text { Silicon } \\
\text { Gresese }\end{array}$ & 500 & 30 & $\sim 0.3$ & to leaks until $30 \mathrm{psi}$. \\
\hline . $\quad$. & $\begin{array}{l}\text { Slightly } \\
\text { Weed }\end{array}$ & 6 & Fig. 9 & $\begin{array}{l}\text { Teflon } \\
\text { Tope }\end{array}$ & 500 & 15 & $>80$ & $\begin{array}{l}3 \text { or more layers of } \\
\text { tepe appliad to } \\
\text { threade. }\end{array}$ \\
\hline Pipe Cap & $\begin{array}{l}\text { Slight ly } \\
\text { Woed }\end{array}$ & 7 & Fig. 9 & $\begin{array}{l}\text { Sillicon } \\
\text { Rubber }\end{array}$ & 300 & 100 & to leaks & $\begin{array}{l}\text { Pressurized thile } \\
\text { assenbly was heated to } \\
32 \sigma^{\circ} \text {. }\end{array}$ \\
\hline$\underset{* A^{n}}{P \text { Plpug }}$ & new & 1 & fig. 7 & $\begin{array}{l}\angle A-C O \\
T-0-T\end{array}$ & 450 & 10 & $>80$ & $\begin{array}{l}\text { Wot a good interference } \\
\text { fit bet meen pipe and } \\
\text { plug. }\end{array}$ \\
\hline Pipe Plux $_{\text {"A* }}$ & New & 2 & Fig. 7 & $\begin{array}{l}\text { Teflon } \\
\text { Tepe }\end{array}$ & 400 & 10 & $>80$ & $\begin{array}{l}\text { At least } 3 \text { layers of } \\
\text { tape applied to } \\
\text { threads. }\end{array}$ \\
\hline $\begin{array}{l}\text { Plpe Plug } \\
\text { "A* }\end{array}$ & w & 3 & Fig. $?$ & $\begin{array}{l}\text { LA-CO } \\
\text { SLIC-Tite }\end{array}$ & 400 & 10 & $>B O$ & \\
\hline${ }_{n \text { ipe }}$ Plug $^{A^{*}}$ & New & 4 & Fig. 7 & $\begin{array}{l}\text { la-co } \\
\text { Slic-tite }\end{array}$ & 300 & 11 & $\sim 15$ & $\begin{array}{l}\text { Recosted thresde with } \\
\text { compound \& tightened. }\end{array}$ \\
\hline $\begin{array}{l}\text { Pipe Plug } \\
\text { "An }^{A^{*}}\end{array}$ & Nen & 5 & Fig. 7 & $\begin{array}{l}\text { LA-CO } \\
\text { Slic-IIto }\end{array}$ & 400 & 21 & Leaks & $\begin{array}{l}\text { Recoated threads with } \\
\text { compound. }\end{array}$ \\
\hline$\underset{* A^{n}}{\text { Pipe Plug }}$ & Now & 6 & Fig. 7 & $\begin{array}{l}\text { Silicon } \\
\text { Grosase }\end{array}$ & 400 & 10 & $>80$ & \\
\hline$\underset{* A^{*}}{\text { Pipe Plug }}$ & new & 7 & Fig. 7 & $\begin{array}{l}\text { Silicon } \\
\text { Ribber }\end{array}$ & 200 & 90 & $\sim 43$ & No lonks unt il 90 pei. \\
\hline$\underset{* \mathbb{N}^{*}}{\text { Pipe Plug }}$ & Now & 8 & Fig. 7 & $\begin{array}{l}\text { Silicon } \\
\text { Rubber }\end{array}$ & $\sim 20$ & 15 & to leaks & $\begin{array}{l}\text { Did not test to higher } \\
\text { preseures. Peserved } \\
\text { for host teat. Plug } \\
\text { put on with sockst. } \\
\text { mrench, ot rap wrench. }\end{array}$ \\
\hline Plpe Plus & Now & 9 & Fig. 7 & $\begin{array}{l}\text { Silicon } \\
\text { Rubber }\end{array}$ & 20 & 60 & No lesks & Heated to $375^{\circ} 5$. \\
\hline
\end{tabular}


TABLE 3. (contd)

\begin{tabular}{|c|c|c|c|c|c|c|c|c|}
\hline $\begin{array}{c}\text { Pipe } \\
\text { Ansenty } 1 y\end{array}$ & Condition & Test No. & $\begin{array}{l}\text { Optical } \\
\text { Profile }\end{array}$ & $\begin{array}{l}\text { Lut ing } \\
\text { Compound }\end{array}$ & $\begin{array}{l}\text { Tightening } \\
\text { Torque, } \mathrm{ft}-1 \mathrm{be}\end{array}$ & $\begin{array}{l}\text { Pressure } \\
\text { psiq }\end{array}$ & $\begin{array}{c}\text { Leak } \\
\text { Rate, cc/anc }\end{array}$ & Coment: 8 \\
\hline $\begin{array}{l}\text { Pipe Cap } \\
\text { "Yw }\end{array}$ & New & 1 & Fig. 4 & $\begin{array}{l}\text { LA-CO } \\
T-0-T\end{array}$ & 300 & 96 & $\sim 37$ & No leaks unt 1196 pol. \\
\hline $\begin{array}{l}\text { Pipe Cap } \\
\text { "ym }\end{array}$ & Nen & 2 & Fig. 4 & $\underset{T-0-T}{L A-C O}$ & 200 & 100 & $\sim 10$ & Wo leaks until 100 pai. \\
\hline $\begin{array}{l}\text { Pipe Cap } \\
\text { "y** }\end{array}$ & $N$ & 3 & Fig. 4 & $\begin{array}{c}\text { LA-CO } \\
\text { Slic-Tite }\end{array}$ & 200 & 10 & $\sim 4$ & $\begin{array}{l}\text { Sat overnight, pipe } \\
\text { compound hardened } \\
\text { somesthet. }\end{array}$ \\
\hline $\begin{array}{l}\text { Pipe Cap } \\
\text { "re }\end{array}$ & New & 4 & Fig. A & $\begin{array}{l}\text { LA-CD } \\
\text { SIIE-Iite }\end{array}$ & 300 & 10 & $\sim$ & $\begin{array}{l}\text { Cleaned theead, } \\
\text { tecooted with compund } \\
\text { teated. }\end{array}$ \\
\hline $\mathrm{Pipe}_{\text {"rm }}$ & New & 5 & Fig. 4 & $\begin{array}{l}\text { LA-CO } \\
\text { Slic-Tite }\end{array}$ & 400 & 100 & Wo leaks & \\
\hline Pipe $^{* Y^{*}}$ & New & 6 & Fig. 4 & $\begin{array}{l}L A-C O \\
T-0-T\end{array}$ & 300 & 100 & No lesks & $\begin{array}{l}\text { Torqued to } 300 \mathrm{ft}-1 \mathrm{~b} \text { s } \\
\text { loosened } 12 \text { times. }\end{array}$ \\
\hline $\begin{array}{l}\text { Pipe CAp } \\
\text { "Yn }\end{array}$ & Hew & 7 & Fig. 4 & $\begin{array}{l}2 A-C 0 \\
T-0-1\end{array}$ & 200 & 80 & $\sim 10$ & No leaks until $80 \mathrm{psi}$. \\
\hline Pipe Cap & New & 8 & Fig. 4 & $\begin{array}{l}L A-C O \\
T=0-T\end{array}$ & 300 & 21 & $\sim 1$ & $\begin{array}{l}\text { Pipe heated to } 300^{\circ} \mathrm{F} \text {. } \\
\text { se fore heat ing } \\
\text { assenbly was leak tight } \\
\text { to } 90 \text { psi. }\end{array}$ \\
\hline $\begin{array}{l}\text { Pipe Cap } \\
\text { "y" }\end{array}$ & New & 9 & $\begin{array}{l}\text { Fig. } \\
T-0-T\end{array}$ & $L A-C O$ & 100 & 20 & $\sim 30$ & \\
\hline $\mathrm{Pipe}_{=\mathrm{r}^{-}}^{\mathrm{Cop}}$ & Now & 10 & Fig. 4 & $\begin{array}{l}\text { Sillicon } \\
\text { Rubber }\end{array}$ & $\sim 60$ & so & $<0.1$ & $\begin{array}{l}\text { Pipe cop put on with } \\
\text { strap wrench. }\end{array}$ \\
\hline Pipe Cop & Hew & 11 & fig. 4 & $\begin{array}{l}\text { LA-CO } \\
\text { Slic-Tite }\end{array}$ & 100 & 100 & No leaks & \\
\hline 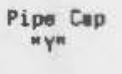 & New & 12 & Fig. 4 & $\begin{array}{l}\text { LA-CO } \\
\text { Slic-Tite }\end{array}$ & 60 & 100 & No leaks & $\begin{array}{l}\text { Lower limit of torque } \\
\text { wench. }\end{array}$ \\
\hline Pipe Cap & Ueed & 9 & fig. 6 & $\begin{array}{l}L A-C O \\
T-Q-T\end{array}$ & 200 & 11 & $\sim$ & \\
\hline Pipe Cap & Uaed & 2 & Fig. 6 & $\begin{array}{l}L A-C O \\
T-0-T\end{array}$ & 300 & 90 & $\sim 2 \times 10^{-2}$ & No leaks unt il 90 psi. \\
\hline Pipe Cap & Used & 3 & Fig. 6 & $\begin{array}{l}\text { LA-CO } \\
\text { Slic-Tite }\end{array}$ & 300 & 100 & No leaks & \\
\hline Pipe Cap & Uoed & 4 & fig. 6 & $\begin{array}{l}\text { LA-CO } \\
\text { Slic-Tite }\end{array}$ & 200 & 100 & Ho leaks & \\
\hline Pipe Cap & Used & 5 & Fig. 6 & $\begin{array}{l}\text { LA-CO } \\
\text { SHic-lite }\end{array}$ & 100 & 100 & No leaks & \\
\hline Pipe Cap & Used & 6 & Fig. 6 & $\begin{array}{l}\text { LA-CO } \\
\text { Slic-Iite }\end{array}$ & 60 & 10 & Leaks & \\
\hline $\begin{array}{l}\text { Pipe Cap } \\
\text { "A* }\end{array}$ & New & 1 & Fig. 5 & $\begin{array}{l}\text { LA-CO } \\
\text { Sl ic-Iite }\end{array}$ & 200 & 100 & No leaks & \\
\hline 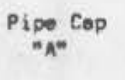 & New & 2 & Fig. 5 & $\begin{array}{l}\text { LA-CO } \\
\text { Slic-Tite }\end{array}$ & 200 & 40 & $<2$ & $\begin{array}{l}\text { anded to } 300^{\circ} \mathrm{F} \text {, cooled } \\
\text { and pressure teated. }\end{array}$ \\
\hline $\begin{array}{l}\text { Pipe Cap } \\
x^{*}\end{array}$ & New & 3 & Fig. 5 & $\begin{array}{l}t A-C O \\
T-Q-T\end{array}$ & 100 & 10 & $>80$ & \\
\hline $\begin{array}{l}\text { Pipe Cap } \\
\text { An }^{n}\end{array}$ & Nen & 4 & Fig. 5 & $\begin{array}{l}\text { LA-CO } \\
T-0-T\end{array}$ & 200 & 10 & $\sim 4$ & \\
\hline Pipe Cap $_{\text {"A* }}$ & How & 5 & fig. 5 & $\begin{array}{l}L A-C O \\
T-Q-T\end{array}$ & 300 & 11 & $<2$ & \\
\hline $\operatorname{Pipe}_{\text {- }^{*}}$ & New & 6 & Fig. 5 & $\underset{T-0-T}{L A-C O}$ & 400 & 10 & $<2$ & \\
\hline
\end{tabular}


TABLE 3. (contd)

\begin{tabular}{|c|c|c|c|c|c|c|c|c|}
\hline $\begin{array}{l}\text { Pipe } \\
\text { Nesembly }\end{array}$ & Condition & Teat Mo. & $\begin{array}{l}\text { Optical } \\
\text { Profile }\end{array}$ & $\begin{array}{l}\text { Luting } \\
\text { Compound }\end{array}$ & $\begin{array}{l}\text { Tightening } \\
\text { Torque, } f t-1 b s\end{array}$ & $\begin{array}{l}\text { Preasure } \\
\text { pain }\end{array}$ & $\begin{array}{l}\text { Leak } \\
\text { Rate, cc/oec }\end{array}$ & Comments \\
\hline$\dot{P}_{\text {ipe }}$ plug & Uned & I & Fig. 8 & $\begin{array}{l}\text { LA-CO. } \\
T-0-T\end{array}$ & 200 & 11 & $\sim 15$ & $\begin{array}{l}\text { Threads not completely } \\
\text { couted with pipe } \\
\text { compound. }\end{array}$ \\
\hline Pipe Plug & Weed & 2 & Fig. 8 & $\begin{array}{l}\angle A-C O \\
T-0-T\end{array}$ & 200 & 100 & No leaks & $\begin{array}{l}\text { Hecauted threads with } \\
\text { thresed compound. }\end{array}$ \\
\hline Pipe Plug & Ulaed & 3 & Fig. $B$ & $\begin{array}{l}\text { LA-CO } \\
\text { Slic-Tite }\end{array}$ & 300 & so & $<2$ & to leaks up to 50 psi. \\
\hline Pipe Plug & Uoed & 4 & Fig. 8 & $\begin{array}{l}\text { LA-CO } \\
\text { Sl ic-Tite }\end{array}$ & 400 & 100 & No lesks & . \\
\hline Pipe Plug & Used & 5 & Fig. 8 & $\begin{array}{l}\text { Silicon } \\
\text { Greane }\end{array}$ & 400 & 10 & 80 & $\begin{array}{l}\text { Threads seized some } \\
\text { threiad denage. }\end{array}$ \\
\hline Pipe Plug & Uaed & 6 & Fig. 8 & $\begin{array}{l}\text { Silicon } \\
\text { Ruber }\end{array}$ & 200 & 100 & to leaks & \\
\hline
\end{tabular}

A pipe thread compound must properly lubricate the threads as well as act as a sealant. When silicon grease was used, a number of thread seizures occurred at the higher torques. The silicon grease evidently does not lubricate the threads sufficiently to prevent thread galling. The thread profile shown in Figure 10 is the profile of a pipe that had been luted with silicon grease. The cap pipe assembly had been tightened and loosened repeatedly (Test 2 , Table 3 , slightly used assembly). The threads seized after repeated tightings, which caused the thread damage shown in Figure 10. Because of the potential problem of thread seizure, silicon grease should not be used as a luting compound.

If the thread compound provides the proper lubrication, the pipe assembly can be tightened and loosened repeatedly without damage to the thread. If thread damage does not occur, the pipe assembly can be sealed repeatedly using essentially the same tightening torques. The $Y$ pipe asesmbly was repeatedly tightened and loosened 12 times without evidence of thread change, Figure 28 (compare with Figure 5). After the repeated tightenings and loosenings, plus applying higher tightening torques, the assembly could still be sealed when the cap was tightened to $300 \mathrm{ft}-1 \mathrm{~b}$ torque. Also, the A pipe-cap pipe-body assembly was tightened and loosened many times and could be sealed consistently by torqueing the cap to $200 \mathrm{ft}-1 \mathrm{~b}$.

The ability of the LA-CO T-0-Tه pipe thread compound to maintain a seal degraded when it was heated. The silicon rubber compound, however, maintained its sealing ability at elevated temperature under all testing conditions. The LA-CO SLIC-TITE compound maintained its sealing ability when heated in a silicon bath, but not when heated in a furnace. 


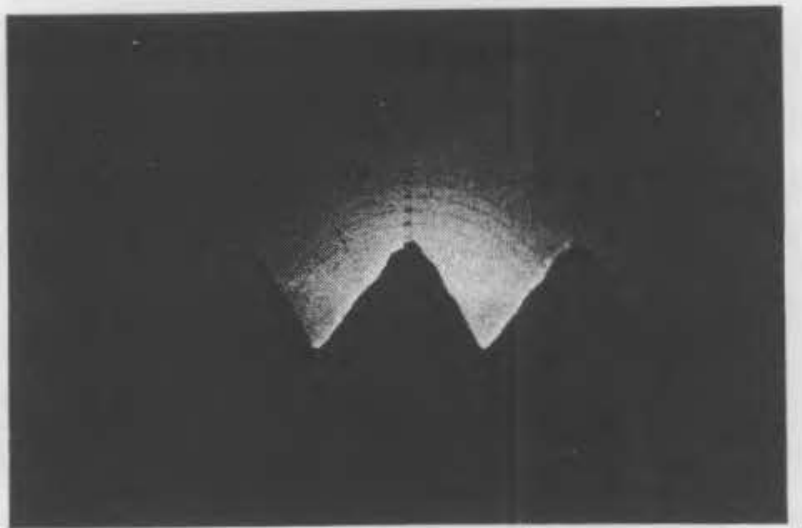

FIGURE 28. Thread Profile of Pipe Body Y

After Repeated Openings and Closures

The $Y$ pipe assembly luted with the LA-CO T-0-T compound was leak tight to $90 \mathrm{psig}$ before heating. After heating to $300^{\circ} \mathrm{F}$, the assembly leaked at 21 psig. The LA-CO SLIC-TITE performed better: before heating, it was leak tight to $100 \mathrm{psig}$ (200 ft-lo torque); after heating at $300^{\circ} \mathrm{F}$, it leaked at 40 psig. Another heating test was conducted using the LA-CO SLIC-TITE compound. The A pipe cap pipe body assembly was luted with the new LA-CO SLIC-TITE compound and the cap was torqued to $200 \mathrm{ft}-1 \mathrm{~b}$. The assembly was heated to $300^{\circ} \mathrm{F}$ in a silicon oil bath, and while at $300^{\circ} \mathrm{F}$, it was pressurized to 100 psig. No leaks were observed. These tests demonstrate that if the LACO SLIC-TITE compounds dries out or bakes during heating, leaks will develop. Heating the LA-CO SLIC-TITE compound under silicon oil prevented it from drying out and a seal was maintained.

The silicon rubber compound proved to be a superior luting compound under all testing conditions. The A plug-tube assembly could not be sealed using any of the standard pipe thread compounds. However, when the silicon rubber compound was applied to the threads, a leak tight seal was obtained to 90 psig (test no. 7, Table 3). The silicon rubber compound provided leak tight seals at low tightening torques. To simulate practices used in the field, the $A$ plug-tube assembly and the $Y$ cap-pipe assembly were luted with the silicon rubber compound and tightened using a strap wrench and an ordinary socket wrench.

The $Y$ cap-pipe assembly was tightened by using a strap wrench on the cap. The pipe body was held in a vice during the tightening operation. A torque wrench was applied to the cap after tightening to measure the tightening torque. It was estimated that the cap had been tightened to about $60 \mathrm{ft}-1 \mathrm{~b}$. 
The A plug-tube assembly was tightened by holding the tube with a strap wrench and screwing the plug into the tube with a socket wrench with a 10-in. handle. The estimated tightening torque was about $20 \mathrm{ft}-1 \mathrm{~b}$. The results shown in Table 3 indicate that the $Y$ assembly was leak tight to 50 psig and the $A$ assembly was leak tight to 60 psig.

Heating the silicon compound to $300^{\circ} \mathrm{F}$ did not affect its ability to seal. The silicon rubber compound was applied to the damaged threads of the slightly used cap-pipe assembly (test no. 7, Table 3) and torqued to 300 $\mathrm{ft}-1 \mathrm{~b}$. The assembly did not leak at $100 \mathrm{psig}$ at room temperature. After heating to $320^{\circ} \mathrm{F}$ and holding for over one hour, the assembly still did not leak at 100 psig.

The sealing mechanism for the pipe thread compounds that were tested is different. The LA-CO T-O-T compound depends on high JCOSIEltensjon to provide seals. The LA-CO SLIC-TITE compound relies on surface tenstion but also has the ability to plug openings due to the Teflon particles suspended in the neutral vehicle. Under internal pressure, the pipe compound is pushed around. As the compound is forced into openings, it dams up and plugs the openings. If the internal pressure continues to increase, ultimately a pressure is reached where the compound collapses and a leak path is opened. When pipe threads are tightened, a point is reached where the threads will not advance any further regardless of the torque applied. If at this point the mismatch area is too great and the pipe compound does not have sufficient viscosity or the potential leak path is not long enough to allow enough pipe compound to dam up to resist the applied pressure, then it would not be possible to obtain a leak tight seal. Consequently, threads not within the specifications might have areas of mismatch that would be continuous at the roots, crests or flanks of the threads and that could not be sealed with standard pipe compounds regardless of the tightening torques applied. If standard pipe compounds are to be used for sealing pipe assemblies, it is recommended that the threads be gauged and that the assemblies be within specifications.

When silicon rubber is used as a luting compound, if properly cured, it provides a plastic material between the threads. The sealing ability of the silicon rubber depends on its mechanical strength and its adherance to the thread surfaces. The resistance to pressure for a plastic (rubber) material 
is higher than a paste or liquid because of its greater molecular bonding (mechanical strength vs viscosity). Consequently, the silicon rubber is capable of sealing areas of greater mismatch between mating parts.

The tests performed have demonstrated that if leak tight seals are to be obtained, then mating parts of a pipe assembly must match and a proper luting compound must be used. The silicon rubber compound that was tested proved to be a superior luting compound. When the silicon rubber compound was used as a luting compound, a wider mismatch between mating parts could be tolerated. Leak tight seals were obtained with pipe assemblies using the silicon rubber compound that could not be sealed using other luting compounds.

\section{FOOD PACK CANS}

The results of the pressure tests with the food pack metal cans are given in Table 4 . The results show leak rates ranging from $<10^{-5}$ to $>2 \mathrm{cc} / \mathrm{sec}$. The variance in the leak rate depends on the quality of the seal. Two cans that had no evidence of leakage when vacuum bubble tested were helium leak checked. The helium leak rate was $3.5 \times 10^{-8} \mathrm{cc} / \mathrm{sec}$ for one can and $4.8 \times$ $10^{-8} \mathrm{cc} / \mathrm{sec}$ for the other can. The helium leak checks tend to confirm that, under careful test conditions (King 1965) leaks as small as $44 \times 10^{-6}$ atm $\mathrm{cm}^{3} / \mathrm{sec}$ can be detected using a yacuum bubble tester. Based on the helium leak tests, it was assumed that if the cans showed no leakage when vacuum bubble tested, they could be considered leak tight $\left(<10^{-7} \mathrm{cc} / \mathrm{sec}\right)$. The leaky cans that were sealed with glyptal enamal paint and silicon compound become leak tight providing the initial leak rate was not too large. If the mechnical seal appeared to be good, i.e., no visible defects such as droops or lips (see Appendix B), and the leak rate did not exceed $\sim 2 \mathrm{cc} / \mathrm{sec}$, then the can could be sealed with silicon compound or glyptal. As the data show in the table, the silicon compound provided leak tight seals to higher pressures then did the glyptal.

The deformation of the can lids varied from can to can. In all the pressure tests performed, only the lids deformed. The sidewall of the cans did not plastically deform. Below about 15 psig the deformation appeared to be reversible except for the flat profile lids that did not have the reinforced rings began to deform irreversibly at about 7 psig. The rings provided additional strength to the lids that deformation below 15 Prevented 
psig. The smaller can lids of the $3-7 / 16-i n . D \times 4-9 / 16-i n, h$ deformed less than the larger cans. The amount of deformation for a $3-7 / 16-i n$. $D \times 4-9 / 16-$ in. $h$ can, a 4-1/16-in. D x 4-11/16-in. $h$ can, and a 4-4/16-in. D x 7-in. $h$ can after they have been pressurized to $35 \mathrm{psig}$. is shown in figure 29 . The lids of the larger cans are bulged and crinkled, where the lids on the smaller can are only slightly bulged. In some cases, the crinkling of the lid caused leaks to occur at the sites of the crinkles. However, in other cases, greater deformation of the lid at higher pressure sealed leaks that were present at lower pressures (see Table 4).

To ensure leak tight seals, irreversible deformation of the lids should be avoided. If internal pressures greater than one atmopshere are anticipated, it is recommended that the seams of the can be coated with silicone rubber compound. Cans coated with silicone rubber (except flat profile lids) will remain leak tight to about 35 psig. A can sealed with silicone rubber was also pressurized to $50 \mathrm{psig}$ and heated to $320^{\circ} \mathrm{F}$ without leaking (Table 4).

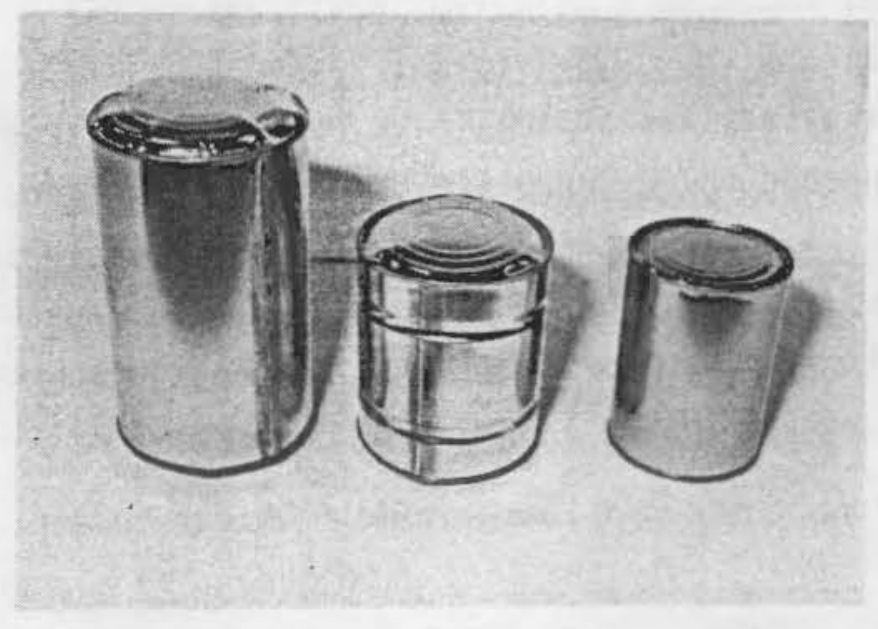

FIGURE 29. Comparison of the Amount of Deformation of Different Size Metal Cans after Pressurization 


\section{TABLE 4. Pressure Test Data for Mechanically Sealed Metal Cans}

\begin{tabular}{|c|c|c|c|c|c|c|}
\hline Cen Stze & $\begin{array}{l}\text { Wull } \\
\text { Micknese } \\
\text { In. }\end{array}$ & $\begin{array}{l}\text { Uid } \\
\text { Thichnese } \\
\text { in. }\end{array}$ & Can 16. & $\begin{array}{l}\text { Presesure } \\
\text { paig. }\end{array}$ & $\begin{array}{l}\text { Leak } \\
\text { Rate } \\
\text { celese }\end{array}$ & Comments \\
\hline $3-7 / 16^{\circ} 0 \times 4-9 / 16^{\mathrm{N}} \mathrm{h}$ & 0.009 & 0.009 & 1 & 5 & $<3 \times 10^{-3}$ & $\begin{array}{l}\text { Cood eppesing sal, olight deforation } \\
\text { but coveraible then pressure } \\
\text { releseed. }\end{array}$ \\
\hline $3-7 / 16^{m} 0 \times 0-9 / 16^{n h}$ & 0.009 & 0.009 & 1 & 16 & $7 \times 10^{-2}$ & $\begin{array}{l}\text { Lids no more distorted than at } 5 \text { psi, } \\
\text { reveraible deformation. }\end{array}$ \\
\hline $3-7 / 16^{m} D \times 4-9 / 16^{n h}$ & 0.009 & 0.009 & 1 & 25 & $\left(1 \times 10^{-5}\right.$ & $\begin{array}{l}\text { Glyptal paint opplied to seana, lida } \\
\text { distorted but not above sidewello. }\end{array}$ \\
\hline $3-7 / 16^{\prime \prime 0} \times 49 / 16^{\circ / h}$ & 0.009 & 0.009 & 1 & 30 & $<3 \times 10^{-3}$ & \\
\hline $3-7 / 16^{n} D \times 4-9 / 16^{n} h$ & 0.009 & 0.009 & 1 & $80-85$ & -- & $\begin{array}{l}\text { Can failed, top lid blom off. Side seans } \\
\text { aplit. }\end{array}$ \\
\hline$\times-7 / 16^{\prime \prime} 0 \times 4-9 / 16^{\prime \prime h}$ & 0.009 & 0.009 & 2 & 16 & 1 & Sala appeared to be good. \\
\hline $3-7 / 16^{\prime \prime 0} \times 4-9 / 16^{\mathrm{mh}}$ & 0.009 & 0.009 & 2 & 35 & $<1 \times 10^{-5}$ & $\begin{array}{l}\text { Silicone rubber compound applied around } \\
\text { sem of top lid. Lids distorted beyond } \\
\text { sidemil. }\end{array}$ \\
\hline $3-7 / 16^{*} 0 \times 4-9 / 16^{m h}$ & 0.009 & 0.009 & 2 & 40 & 0.04 & $\begin{array}{l}\text { Bubblo sppared in rubber compound. Lide } \\
\text { bulged mbove sidewall, erinkles atasting } \\
\text { to form in } 1 \text { ids. }\end{array}$ \\
\hline $3-7 / 16^{\mathrm{ND}} \times \mathrm{a}-9 / 16^{\mathrm{mh}}$ & 0.009 & 0.009 & s & 16 & $>2$ & Seams look all right. \\
\hline $3-7 / 16^{n D} \times 4-9 / 16^{n h}$ & 0.009 & 0.009 & 3 & so & $<1 \times 10^{-5}$ & $\begin{array}{l}\text { Stlicone compound applied to seans. } \\
\text { thated to } 320^{\circ} \mathrm{F} \text { under preasure. }\end{array}$ \\
\hline $3-7 / 16^{n D} \times 4-9 / 16^{m h}$ & 0.009 & 0.009 & 3 & $70-80$ & - & Can rolled, top lid blew off. \\
\hline $4-1 / 16^{n 0} \times 4-11 / 16^{m h}$ & 0.010 & 0.009 & 1 & 17 & $<1 \times 10^{-5}$ & $\begin{array}{l}\text { Lid deformed, lid sealed with notorized } \\
\text { can sealer. }\end{array}$ \\
\hline $4-1 / 16^{*} D \times 4-11 / 16^{\mathrm{m} h}$ & 0.010 & 0.009 & 1 & 21 & $<1 \times 10^{-5}$ & Lido deformod, crinklo pattern. \\
\hline $4-1 / 16^{\prime \prime 0} \times 4-11 / 16^{m} \mathrm{~h}$ & 0.010 & 0.009 & 1 & 65 & $<1 \times 10^{-5}$ & $\begin{array}{l}\text { Lid highly doformed, bulged and crinkled, } \\
\text { no observible deformat ion of can sidewall. }\end{array}$ \\
\hline $4-1 / 16^{\mathrm{m} D} \times 4-11 / 16^{\mathrm{m} h}$ & 0.010 & 0.009 & 1 & -89 & $\cdots$ & Can failure, top blew off. \\
\hline $4-1 / 16^{n} \mathrm{D} \times 4-11 / 16^{n h}$ & 0,010 & 0.009 & 2 & 16 & $<1 \times 10^{-5}$ & $\begin{array}{l}\text { Slight lid bulge roversible, lid sealed } \\
\text { with motorized can sesler. }\end{array}$ \\
\hline $4-1 / 16^{* 0} \times 4-11 / 16^{m h}$ & $0.01 n$ & 0.009 & 2 & 74 & $<1 \times 10^{-5}$ & Lid greatly deforned, bulged, crinkled. \\
\hline $4-1 / 16^{\prime \prime} D \times 4-11 / 16^{n h}$ & 0.010 & 0.000 & 2 & 80 & $>10^{-5}$ & $\begin{array}{l}\text { Sall bubbles foraing around lid seens. } \\
\text { Lids deformed only slightly more than at } \\
74 \text { pgi. No distortion of can sidewall. }\end{array}$ \\
\hline $4-1 / 16^{n} D \times 4-11 / 16^{n} h$ & 0.010 & 0.009 & 2 & $84-89$ & - & Con failed, top lid blem off. \\
\hline $4-4 / 16^{m} D \times 4-11 / 16^{m} \mathrm{~h}$ & 0.0082 & 0.0076 & 3 & s & $6 \times 10^{-3}$ & Seal appeared good. \\
\hline $4-4 / 16^{\mathrm{mD}} \times 4-11 / 16^{\mathrm{m} h}$ & 0.0082 & 0.0076 & 3 & 10 & 0.75 & $\begin{array}{l}\text { Lid deformed, glyptal paint applied to } \\
\text { seans but did not seal hecnuse of lid } \\
\text { deformation. }\end{array}$ \\
\hline $4-4 / 16^{*} D \times 4-11 / 16^{* \prime h}$ & 0.0082 & 0.0076 & 5 & 5 & $<1 \times 10^{-5}$ & Slight deformation of lid. \\
\hline $4-4 / 16^{\prime \prime 0} \times 4-11 / 16^{m} \mathrm{~h}$ & 0.0062 & 0.0076 & 3 & 11 & 0.6 & Lid bulged, crinkled. \\
\hline $4-4 / 16^{n} 0 \times 4-11 / 16^{n h}$ & 0.0082 & 0.0076 & s & 16 & 0.8 & Lid highly deformed. \\
\hline $4-4 / 16^{n} D \times 4-11 / 16^{\mathrm{m} h}$ & 0.0082 & 0.0076 & 5 & $25-30$ & - & $\begin{array}{l}\text { Con failed, top lid ripped st junction of } \\
\text { lid end aidewall. }\end{array}$ \\
\hline $4-4 / 16^{\prime \prime D} \times 7^{7 h}$ & 0.010 & 0.010 & 1 & 5 & $6 \times 10^{-3}$ & $\begin{array}{l}\text { Top lid sealed with motorized can } \\
\text { sealer. Leak occurred at lid sesled by } \\
\text { manufect urer. }\end{array}$ \\
\hline $4-4 / 16^{* 0} \times 7^{m h}$ & 0.010 & 0.010 & 1 & 15 & $<1 \times 10^{-5}$ & $\begin{array}{l}\text { Can lida highly bulged. Deformation } \\
\text { atopped loakage. }\end{array}$ \\
\hline
\end{tabular}




\section{TABLE 4. (contd)}

\begin{tabular}{|c|c|c|c|c|c|c|}
\hline Can $5 i z 0$ & $\begin{array}{l}\text { Well } \\
\text { Thicleneas } \\
\text { in. }\end{array}$ & $\begin{array}{l}\text { Lid } \\
\text { Thicknese } \\
\text { in. }\end{array}$ & Can No. & $\begin{array}{l}\text { Preanure } \\
\text { poig }\end{array}$ & $\begin{array}{l}\text { Leak } \\
\text { Rate } \\
\text { cclaec }\end{array}$ & Conents \\
\hline $4-4 / 16^{*} D \times 7^{m h}$ & 0.010 & 0.010 & 2 & 7 & $3 \times 10^{-3}$ & $\begin{array}{l}\text { Bubbles formed at bottom } 1 \text { id installed by } \\
\text { manufact urer. }\end{array}$ \\
\hline $4-4 / 16^{m} 0 \times 7^{m h}$ & 0.010 & 0.010 & 2 & 11 & $10^{-4}$ & $\begin{array}{l}\text { Lide defornend. Deformation st opped } \\
\text { leakege from bottom lid. Top lid leaks } \\
\text { slightly. }\end{array}$ \\
\hline $4-4 / 16^{n 0} \times 7^{n h}$ & 0.010 & 0.010 & 2 & 55 & $<1 \times 10^{-5}$ & $\begin{array}{l}\text { Lida bulged about } 3 / 8^{*} \text { soove sidemell. } \\
\text { Deformation stopped losks. }\end{array}$ \\
\hline $4-4 / 16^{m} 0 \times 7^{m h}$ & 0.010 & 0.010 & 2 & 60 & - & Can failed, bottom lid blom off. \\
\hline $4-4 / 16^{\circ} 0 \times 7^{m} h$ & 0.010 & 0.010 & 3 & 10 & $>2$ & $\begin{array}{l}\text { Leaka from botton lid installed by } \\
\text { manufacturer. }\end{array}$ \\
\hline $4-4 / 16^{n} 0 \times 7^{n h}$ & 0.010 & 0.010 & 3 & 70 & - & Can failed, bottom lid blown off. \\
\hline
\end{tabular}

An attempt was made to determine quantitatively the amount of deformation a can undergoes as it is pressurized. A water displacement method was used to measure the volume change of a can as it was pressurized. Figures 30 and 31 show plots of the volume change versus pressure for the $4-1 / 16-i n$. $D \times 4-$ $11 / 16-i n$. $h$ and the $4-4 / 16-i n$. $D \times 7-i n$. $h$ cans. The curves have the same general shape except for the one smaller can. The plots show that the percent volume change versus pressure varies from can to can. It can be concluded from the tests performed that it would be difficult to predict the pressure inside a can by its volume change. However, if a better setup were used, possibly a better correlation could be made. Due to the insensitivity of the apparatus used, the uncertainty in the measurements is about $\pm 50 \%$.

At least one can from each of the different size cans tested was pressurized to failure. The cans failed by one of the lids separating from the can body. Two types of lid failure were noted. The lids failed either by tearing at the junction of the lid and the can body (Figure 32) or by uncrimping (Figure 33). Failure by tearing was observed only with the cans that had lid thicknesses of 0.0076 inch or if the lid had a cut-over type of defect (see Appendix B, Figure B.6) that weakened the lid at the junction of the lid and the can body. The thicker can lids (0.009 inch) had greater strength to withstand the bending and shear stresses set up at the lid-can body junction so the can failed by uncrimping the mechanical seal. The lid that uncrimped first was usually the one that leaked first. In any event, the lid that failed first did not have as tight a seal as the other lid. The pressure tests indicate that when the cans are properly sealed, they are gas tight at pressures far in excess of the pressure listed in the Federal Specification. If the cans are nermetically sealed, they will not leak powders such as $\mathrm{UO}_{2}$ or $\mathrm{PuO}_{2}$. 


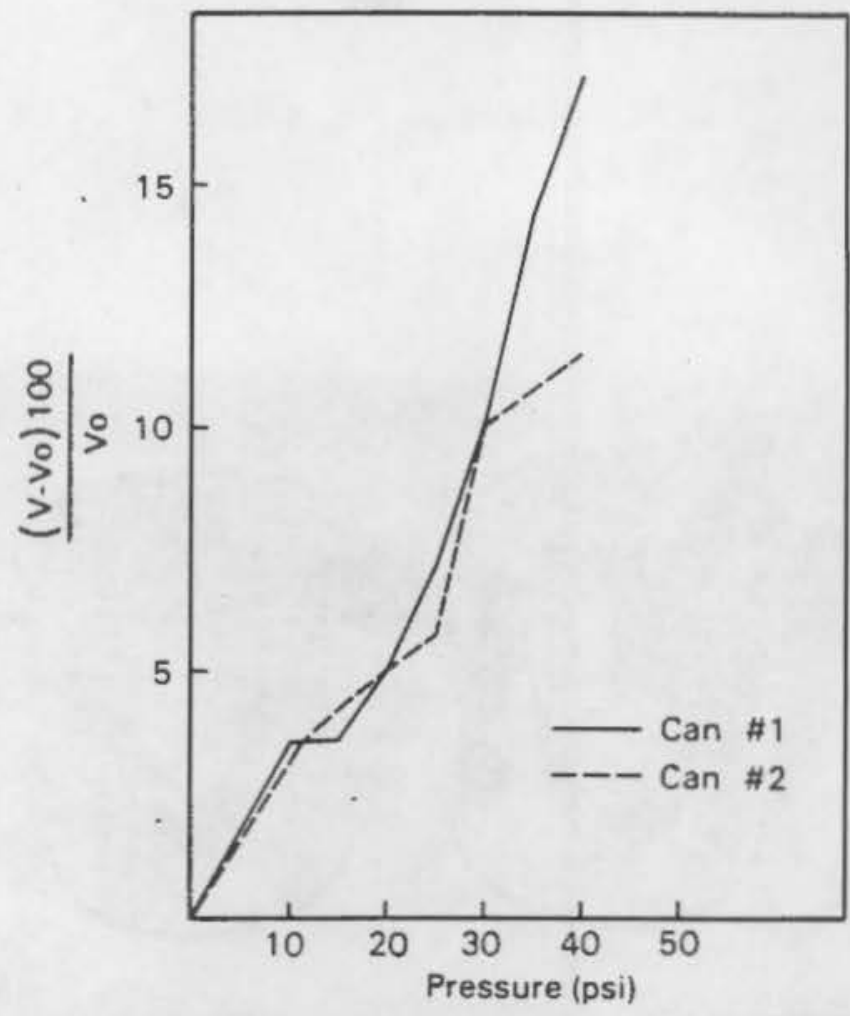

FIGURE 30. The Volume Change of Metal Cans 4-1/16-in. D x 4-11/16-in. H Under Pressure

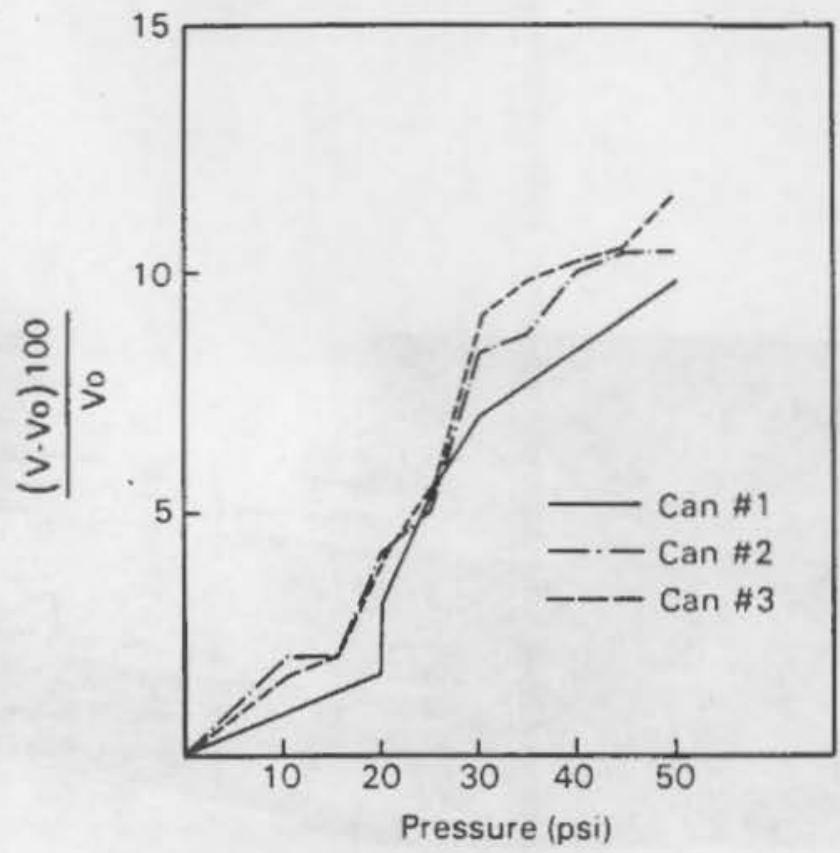

FIGURE 31. The Volume Change of Metal Cans 4-4/16-in. D x 7-in. H Under Pressure 


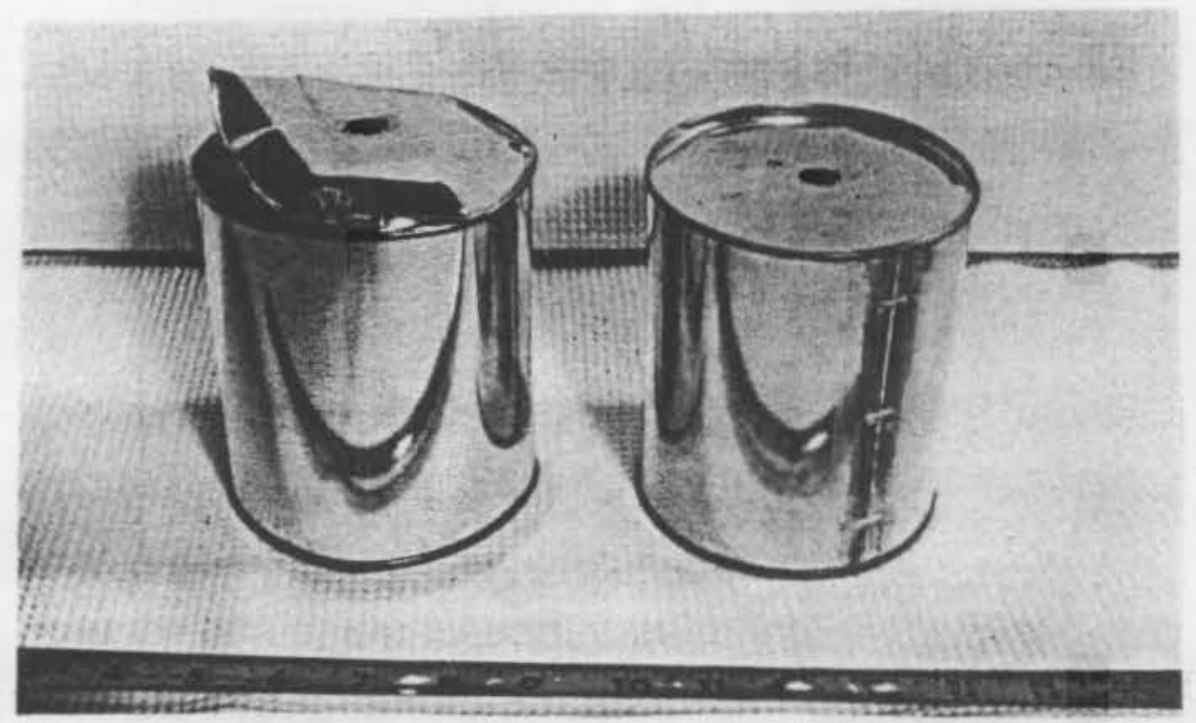

FIGURE 32. Lid Failure by Tearing Under Pressure

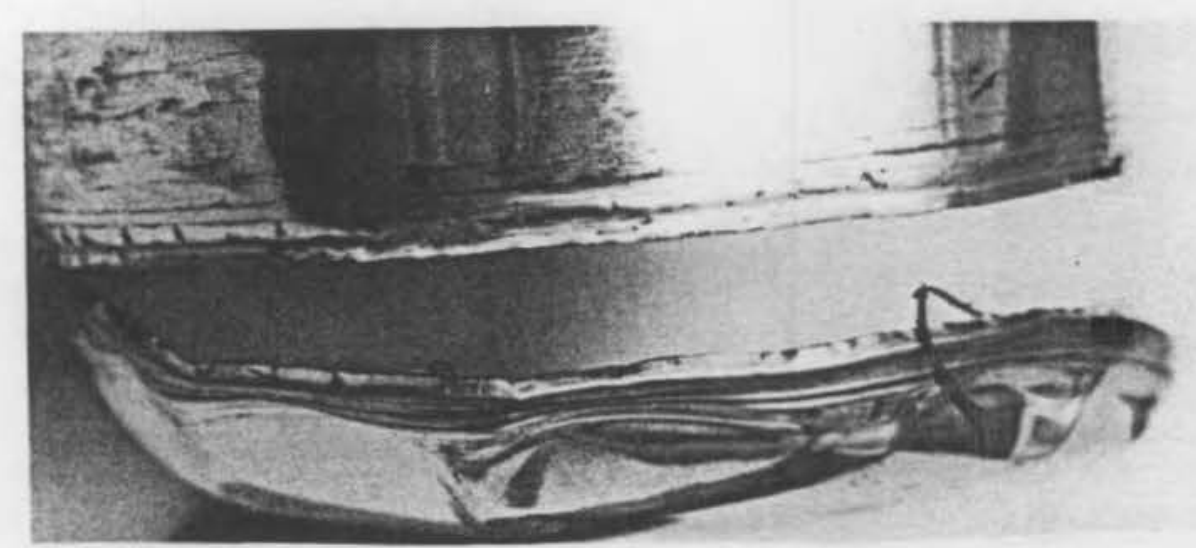

FIGURE 33. Lid Failure by Uncrimping Under Pressure 


\section{IMPACT AND HEATING TESTS}

The packaging configuration shown in Figure 25 (horsehair padding) was the first $6 \mathrm{M}$ configuration tested. Only slight damage occurred to the $6 M$ drums after the 30-foot end-on impact (Figure 34 ). The $2 R$ vessels were unmarked. The only noticeable damage to the celotex insulation was to the top disc which was in contact with the top of the $2 R$ vessel. The disc was indented about $1 / 2$ inch due to the impact of the $2 R$ vessel. The $2 R$ vessel was leak tested after the impact and no leaks were detected. After heating to $300^{\circ} \mathrm{F}$ for a little over an hour, it was leak tested again and had a leak rate of $\sim 4 \mathrm{cc} / \mathrm{sec}$ at $15 \mathrm{psig}$. The silicone grease used as a luting compound did not maintain a seal when heated to $300^{\circ} \mathrm{F}$. The pressure buildup inside the $2 R$ vessel continued to increase during heating until the vessel was removed from the furnace. The maximum pressure recorded was 19.5 psig. Calculations indicate that the pressure buildup due to the expansion of air should have only been about 6 psig. The steady increase in pressure was indicative of outgassing from the rubberized horsehair. Inspection of the horsehair after the heating test showed some discoloration of the horsehair.

The food pack cans were damaged such that a pressure test could not be performed. A screw fitting that had been screwed into the lid of the can containing the sand had been torn loose (Figure 35). The sand inside the can was dispersed inside the larger food pack can (Figure 36). The horsehair packing did not provide enough resistance to prevent the top can from damaging the bottom can during impact.

The packaging configuration shown in Figure 25 (bottom half) was the second configuration tested. After impact the drum sidewall on one side of the drum was compressed about 1 inch shorter than its original height. Other than this, the drum was not damaged. The $2 R$ container was undamaged and the celotex board on top of the $2 R$ pipe was indented about $1 / 2$ inch, as in the first test. The $2 R$ container was leak checked after impact and no leaks were detected using a bubble leak detector. The pressure buildup during furnace heating did not exceed the pressure ( 7 psig) expected for expansion of the air inside the $2 R$ vessel. The $2 R$ vessel was leak checked after the heat test and no leaks were detected using a bubble leak detector. The threads of the $2 R$ assembly were luted with silicon rubber. 


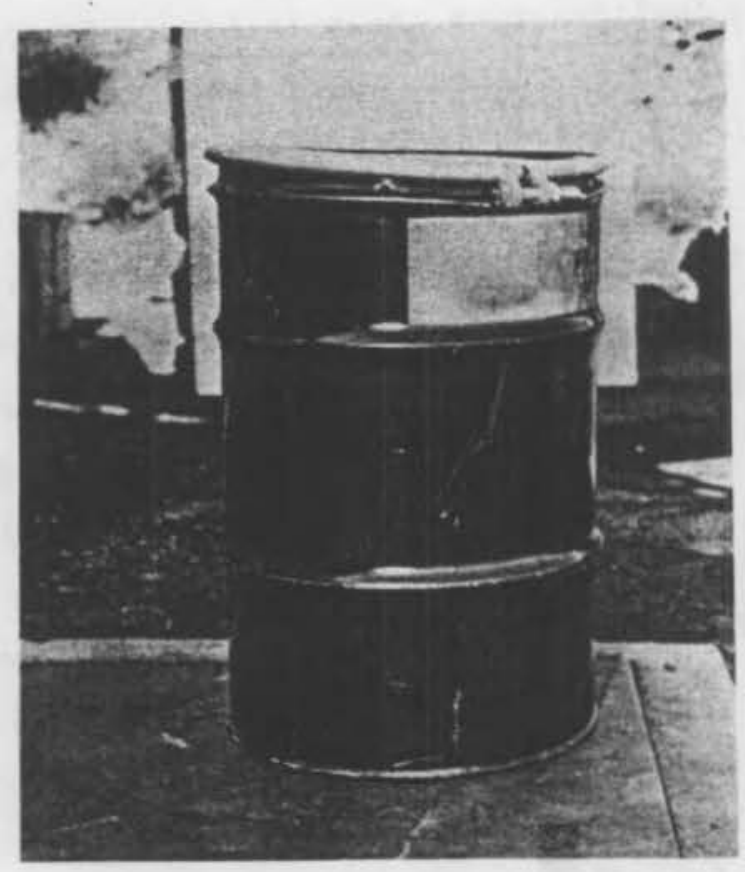

FIGURE 34. Damage to $6 \mathrm{M}$ Container After 30-Foot End-On Impact

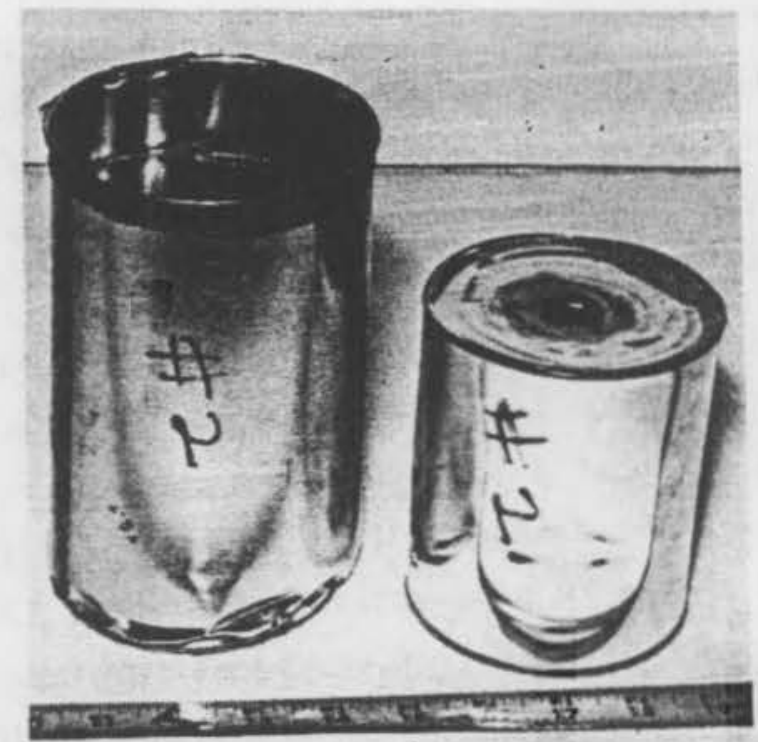

FIGURE 35. Damaged Metal Can Containing Sand after First 30-Foot Impact Test 


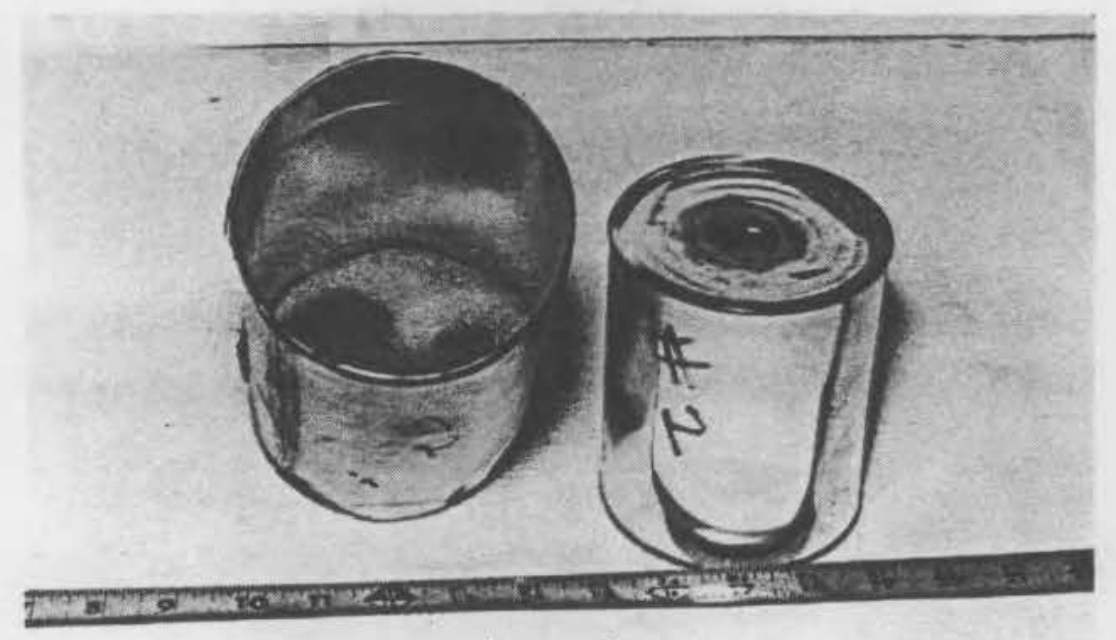

FIGURE 36. Damaged Larger Metal Can after First 30-Foot Impact Test

The can on the bottom of the column, which was the first to be impacted, was damaged (can \#4, Figure 37 ). The top of the can was indented about $3 / 4$ inch on one side. The indent was caused from the shifting of the empty can used as an impact limiter. If the empty can had remained in line with the other can, the loaded can (\#4) would not have sustained as much damage. Can \#3, which was positioned on top of the other loaded can, had only minor dents. The inner food pack cans containing the sand were undamaged. However, the empty cans used as spacers and impact limiters were crushed about $1 / 2$ inch. The empty cans proved to be adequate impact limiters. The cans containing the sand were leak checked after the impact and heating and no leaks were detected using a bubble leak detector.

For the third impact test performed, a $2 R$ vessel with a plug closure was used. The cans were stacked inside the $2 R$ vessel between disk spacers as shown in Figure 26 (top figure). The drum had no noticeable damage after the impact, except the locking ring on the drum head was slightly displaced. The $2 R$ container was undamaged; however, the celotex board on top of the pipe was more indented than in the other tests. This was due to the smaller surface area of the pipe plug impacting on the celotex board. The $2 R$ container was leak checked after impact and no leaks were detected. Silicon rubber compound had been applied to the threads prior to installing the plug. The pipe plug had been tightened in the tube by using a socket wrench (10-inch handle) with a strap wrench securing the tube. The estimated tightening torque was about $60 \mathrm{ft}-\mathrm{lb}$. 


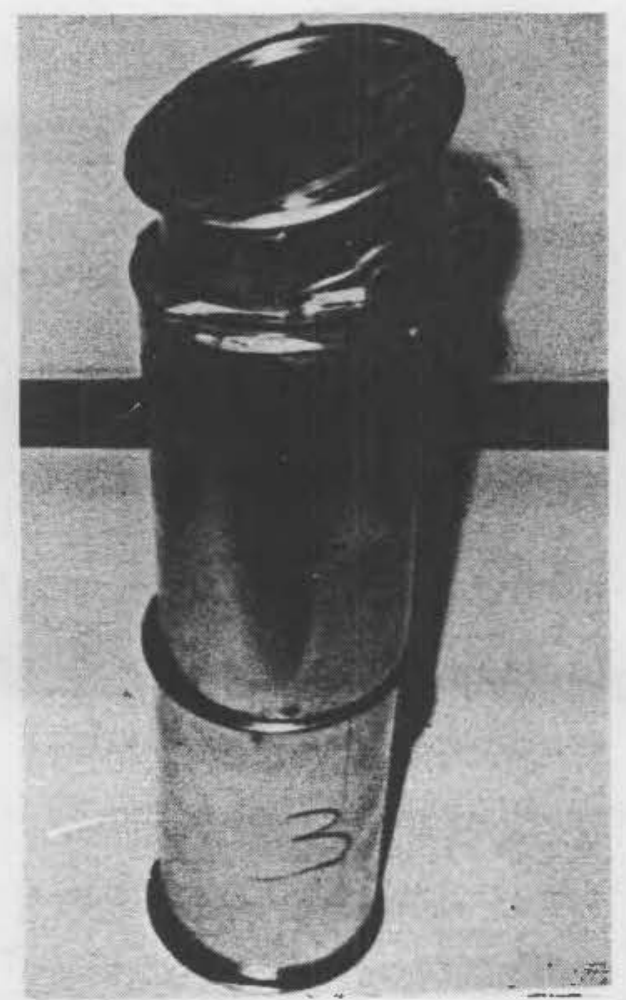

FIGURE 37. Damaged Larger Metal Can after Second 30-Foot Impact Test

To determine the effect of higher pressure buildup during heating, the $2 R$ vessel was vented so that a differential pressure could build up between the metal cans and the $2 R$ vessel. This situation might occur if the $2 R$ vessel was breeched during an accident. Also, one of the larger metal cans containing the smaller can with sand inside was vented by means of a loose fitting plug installed in the top lid of the can. The other larger can was sealed so that it was leak tight and would be pressurized under heating. The smaller cans containing the sand were also sealed so that during heating, they would be pressurized.

The combination of the spacer disks and empty cans (impact absorbers) proved effective in protecting the metal cans. The larger metal can that was vented was not damaged and retained its original shape. The other larger can that was sealed was distorted. The lids were bulged similar to the large can shown in Figure 28. It was speculated that the can must have been pressurized between 45 and 55 psig to cause the lids to deform as much as they did. It was speculated that some water must have gotten into the can when it was pressure tested under water prior to the impact and heating test. Examination of the can after the tests showed corrosion around the top lid. The can leaked when bubble tested. 
The smaller cans were also distorted indicating that they had been pressurized. The amount of distortion was more than could be accounted for just from expansion of air inside the can. It was estimated that the pressure must have been in excess of 50 psig. A thermogravimetric analysis was made of the sand to determine if any volitile material was being released when the sand was heated to $300^{\circ} \mathrm{F}$. A weight loss of between 0.3 to $0.5 \%$ was observed when different samples of sand were heated from $80^{\circ}$ to $300^{\circ} \mathrm{F}$. The most likely substance to be released in that temperature range would be water. The vaporization of water could account for pressures in excess of 50 psig inside the metal cans. The small cans were bubble tested and both cans leaked.

A fourth impact test was made with a packaging arrangement shown in Figure 26 (bottom figure). The impact absorbers were placed on either end of the cans to protect the 4-1/16-in. $D \times 4-11 / 16-i n . h$ and the $4-1 / 4-i n$. $D \times$ 7-in. $h$ cans during impact. The impact absorbers were placed at either end since during an accident it cannot be predicted beforehand which end of the container might be impacted. The same metal plates that were used to align the cans in test number 3 were used in the number 4 test. Since the height of the spacer cans was reduced from those used in test number 3 , smaller cans were placed inside the larger cans to stiffen the absorber assemblies so that they would not bottom out and transmit the impact force to the product cans.

The $2 R$ vessel was sealed with a silicon rubber compound. After impact the $2 R$ vessel was leak tested, and no leaks $\left(<10^{-5} \mathrm{cc} / \mathrm{sec}\right)$ were observed.

The damage to the $6 M$ drum was similar to the damage incurred in the previous tests. The celotex insulation was damaged very little. A plywood plate $10-i n . \times 10-i n$. $\times 1-1 / 8-i n$. thick was placed on top of the $2 R$ vessel to protect the celotex and to determine if the impact absorbers would protect the cans under a higher $g$ force.

The impact absorbers worked well. No damage occurred to the 4-1/4-in. D $x 7-i n$. $h$ cans, and no gas leaks were observed when the cans were bubble tested. A small amount of damages to the lid of one of the $4-1 / 16-i n$. $0 \times 4-$ 11/16-in. $h$ cans was noted. The damage was due to the force exerted on the lid during impact by the inner $3-1 / 2-i n$. $D \times 3-1 / 2-i n$. $h$ can that contained lead shot and sand. The other 4-1/16-in. D $\times 4-11 / 16-i n$. h can that contained loose packed lead shot and sand was not damaged. After the impact test, the metal cans were placed in an oven and heated at $300^{\circ} \mathrm{F}$ for one hour. After 
heating, the cans were bubble tested and no gas leaks were observed. The cans did not deform irreversibly during heating so the pressure exerted during heating must have been below 15 psig.

The impact and heating tests have shown that gas tight seals can be maintained under accident conditions for the packaging configuration shown in Figure 26 (bottom figure) for the 6M container.

In order to maintain hermetic seals, the product cans must be sealed using a properly adjusted can sealing machine. Instructions are given in Appendix B for properly adjusting several types of sealing machines. Appendix $C$ also provides instruction for properly sealing metal cans.

Material that is to be packaged in the $6 \mathrm{M}$ container should be stable and not decompose or outgas when subjected to temperatures up to $300^{\circ} \mathrm{F}$. Pressures in excess of 15 psig will plastically deform the can lids and could cause leakage to occur.

To reduce the differential pressure between the atmopshere inside the sealed metal cans and the $2 R$ vessel, the $2 R$ vessel should be sealed. The $2 R$ vessels can be sealed when the threads are luted with a high temperature silicon rubber compound and the cap or plug is tightened using a torque of at least a $100 \mathrm{ft}-1 \mathrm{bs}$. The seal will remain gas tight $\left(<10^{-5} \mathrm{cc} / \mathrm{sec}\right)$ even up to pressures of $100 \mathrm{psig}$ and temperatures of $300^{\circ} \mathrm{F}$. Appendix $\mathrm{C}$ contains a procedure for obtaining gas tight seals with $2 R$ vessels.

Finally, the metal cans must be protected from being damaged in the event of an accident by properly packaging them inside the $2 \mathrm{R}$ vessels. The stacking arrangement shown in Figure 26 protected the metal cans with payloads of up to $2.4 \mathrm{~kg}$ from damage when the $6 \mathrm{M}$ drum was dropped $30 \mathrm{ft}$ end on. 


\section{REFERENCES}

Blankenship, R. W. 1980. Hypothetical Accident Conditions Free Drop and Thermal Tests Specification 6M. LA-8366-MS, LoS Alamos National Laboratory. Los Alamos, New Mexico.

Chalfant, G. G. 1984. Safety Analysis Report - Packages USA/9965/BLF USA $9968 /$ BLF. DPSPU 83-124-1, E.I. de Pont de Nemours and Co., Inc., Aiken, South Carotina.

King, C. R. 1975. Vacuum Leak Testing of Radioactive Source Capsules. ORNL3664, Oak ridge National Laboratory, Oak Ridge, Tennessee.

U.S. Nuclear Regulatory Commission (NRC). 1975. U.S. Nuclear Regulatory Guide 7.4. NRC, Washington, D.C. 

APPENDIX A

CORRESPONDENCE BETWEEN NRC AND DOT 


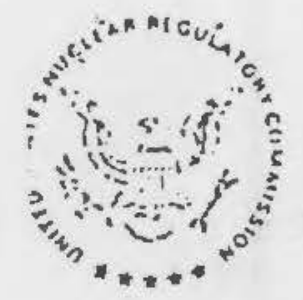

\author{
UNITED:I:TES \\ NUCLEAR REGULATUTIY COR::IISSION \\ WASHINGTON. D. C. 20555
}

$$
\text { JAII I } \overline{D S O}
$$

Mr. Richard R. Rawl

U. S. Department of Transportation

of itice of Hazaroous Materials Operations

Washington, D.C. 20590

Dear Mr. Rawl:

This is in regard to your letter of June 5, 1979, cencerning the DOT Specification 6M package and its ability to meet the 1973 IAEA criteria.

The $6 M$ packaging consists of an inner Soec. $2 R$ containment vessel and a steel drum overpack containing a media to provirie impact and therme protection for the inner vessel. We believe the current $6 M$ specification is sufficient for the overpack but not for the inner vessel.

He believe package specifications should contain sufficient information to assure that harchare fabricated in accordance with the specification will meet all pertinent requirements. While this may be possible with the current specifications, the information and requirements are not suficicat ic sssure the $2 R$. vessel would meet the newiy quantified leak-rates in IAEA requiations. Secondly, the $6: \%$ Specification requires that largo oujntities of radioective material in norma? form nust te packaced in one ci mije sealed and leak tight metal caus or polyethylene bottles within the $2 \pi$ vessel. liavever,

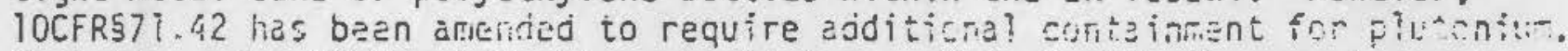
We believe the $6 M$ Specification should be consistent with the requircments of 10 CFR Part 71 . Finally, the maximum heat load permitted in various configurations of the packege should be tabijiats.

The basic need is for a Specification that will assure the $2 R$ vessel and the secondary iriner container will meet the pruposed DOT/ARC requirements. This need also extends to other DOT Specification packeoes which are authorized for greater then Type A quentities in normal form.

He believe that consideration should be given to restructuring DOT specification packayes to limit the contents in normicl form to no wore than a Type A quantity. The administrative reasons that freviously existed for zuthorizing Type 8 packaging through engineering spacifications in Federal Rules have been el imineted oy inproverients injde to the MPC licensing mectienism. Package designs are now authorized by Certificate of Compliance rütinar than by specific amendment of individual possession or iacility licenses; also 
other users may now simply resister under 10CFP\$71.12 or $49 C F R 173.393 a$ without submitting an epplication or obtaining a speciric approval. Under the present system, there apfats zo be essentially io need to continue authorizing Type 5 packages tnrougn DOT Specifications.

Sincerely,

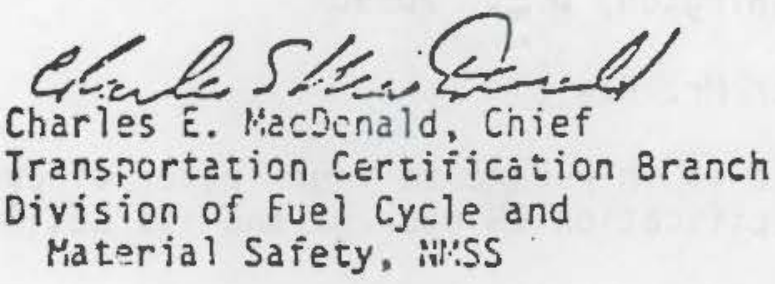




\section{APPENDIX B}

INSTRUCTIONS FOR PROPERLY ADJUSTING SEALING MACHINES 


\section{APPENDIX B}

\section{INSTRUCTIONS FOR PROPERLY ADJUSTING SEALING MACHINES}

Mechanically sealed food pack cans have been in existence for many years. The process relating to the manufacture of the food pack cans has been refined to the point that very few rejects are obtained. However, the key step in producing hermetically sealed food pack cans is to use a properly adjusted sealing machine and cans that are in good shape. Three common styles of sealing machines are shown in Figures B.1 through B.3. The information that follows has been abstracted from the operating instructions for the can sealers shown. Before operating a can sealer, it is imperative that the operating instructions supplied with the sealing machine be read and followed. If the instructions are not available, contact the manufacturer to obtain a copy.

The information concerning the kinds of defects and their causes was taken from a publication entitled Top Double Seam Inspection and Evaluation Round Sanitary Style Steel Cans published by the American Can Company. All the sealing machines shown use the same principal for making mechanical seais. The can is placed on a turntable or base plate, then it is raised until the lid to be sealed is engaged in a chuck. A flywheel, crank or pulley is then turned either by hand or motor, and the first seaming roller contacts the can lid. This operation tucks the curled edge of the lid underneath the flange of the can body as illustrated in figure B.4. As the can continues to rotate, the first roller backs off and the second seaming roller moves in against the lid and presses the folds of metal tightly together, squeezing the compound lining into the spaces between the metal (Figure B.5).

Various kinds of defects can occur if the sealing machine is not adjusted properly. These are:

- cut overs

- cut seams

- droop or lips

- false seams

- spinners. 


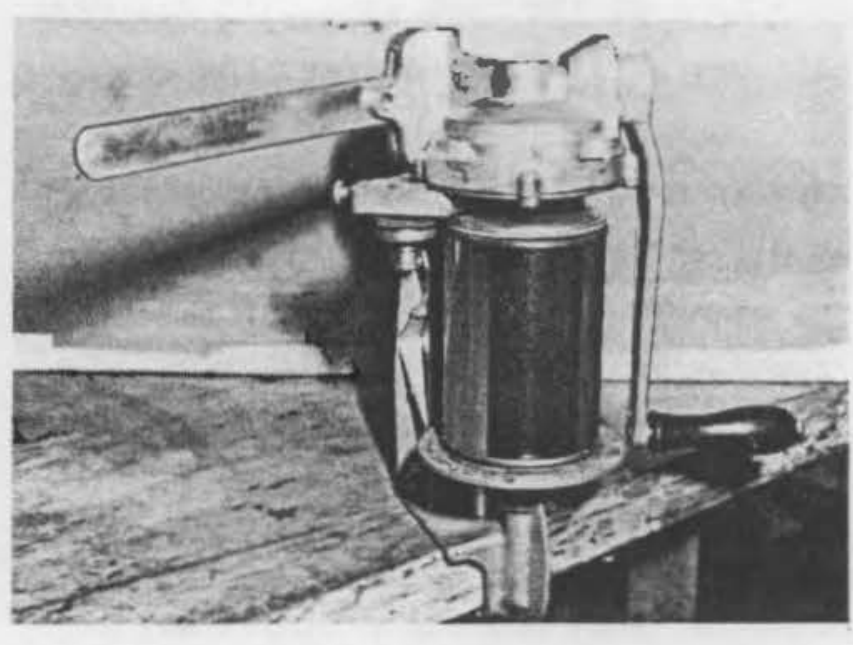

FIGURE B.1. Hand-0perated Can Sealer

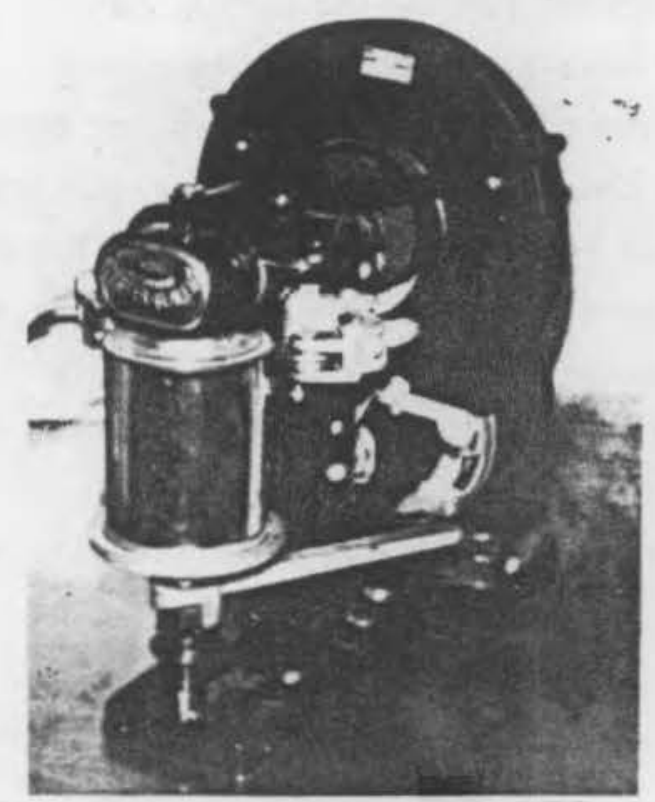

FIGURE B.3. Motorized Can Sealing Machine

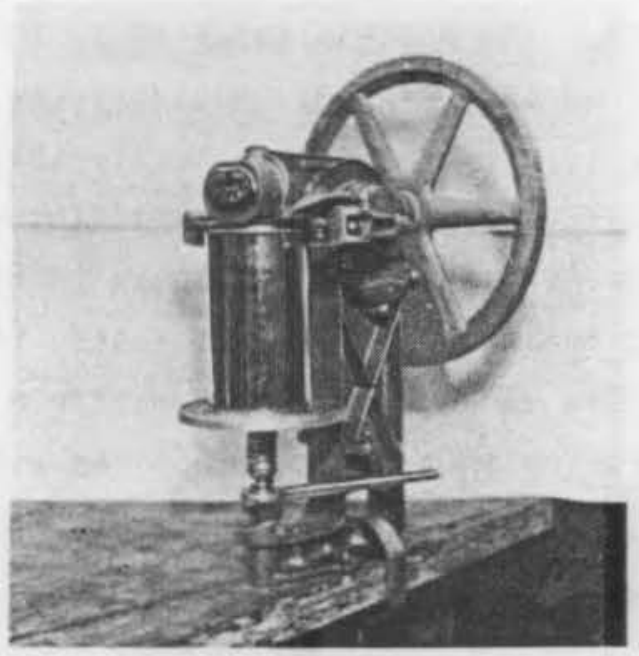

FIGURE B.2. Hand-0perated Can Sealer with Fly wheel

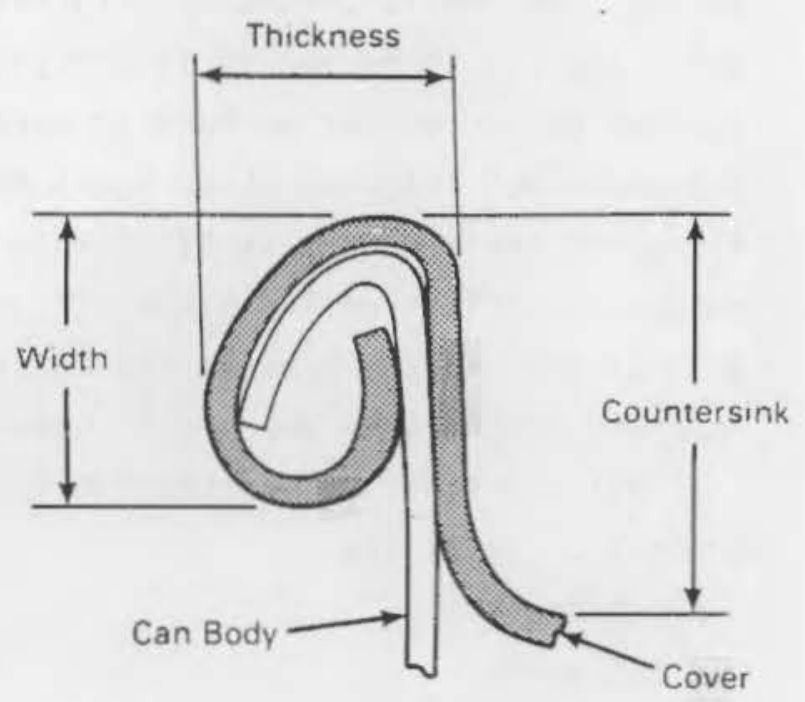

FIGURE B.4. Section View of Crimp Seal After First

Seaming Roll Operation 


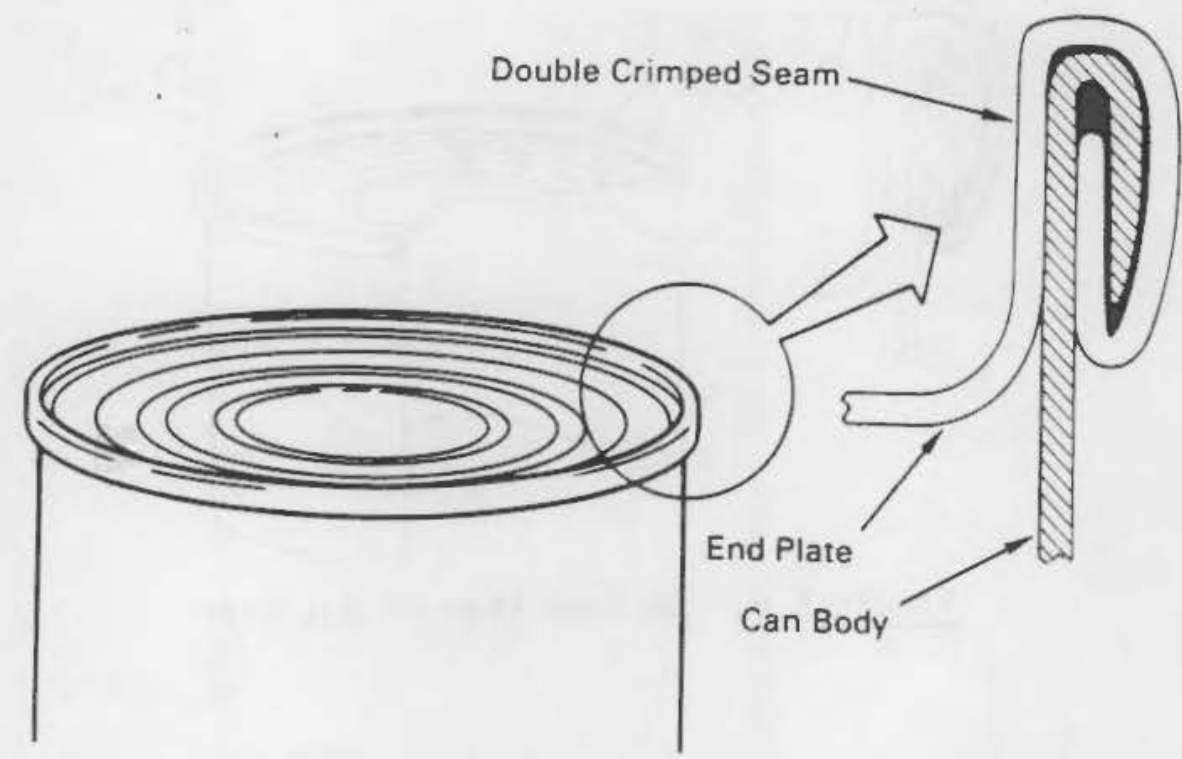

FIGURE B.5. Section View of Completed Seam After Second Seaming Roll Operation

A cut over is a sharp edge that forms where the lid folds over the can body (Figure B.6). A slight cut over is not too serious and probably will not cause leakage. Severe cut overs, however, can cause a fracture to occur in the lid. The possible causes of cut over are:

- incorrect vertical alignment of first seaming roll groove to chuck (clearance between the shoulder of the seaming roller and the top of the chuck should be 0.001 to 0.002 inch.)

- vertical play of first operation roller plug not to exceed 0.002 inch

- worn chuck around the top edge

- first or second seaming rolls set too tight

- worn seaming roll grooves

- solid or semisolid product trapped under lid

- excess solder at can body lap

- excessively long body, hooks.

A cut seam is a fracture in the outer rim of the lid (Figure B.7). The possible causes of this type of defect are:

- seam too tight

- excess solder at can body lap

- defective lid

- excess sealing compound. 


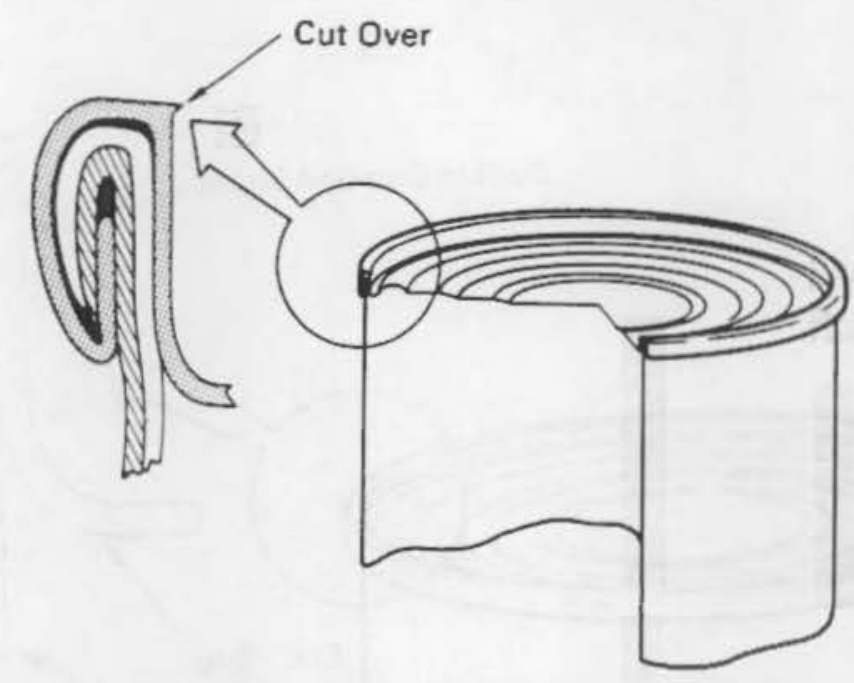

FIGURE B.6. Section View of Cut Over

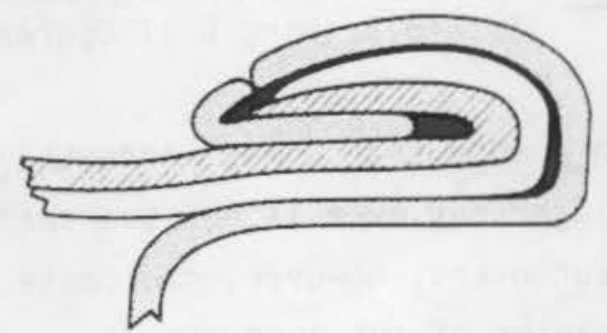

FIGURE B.7. Section View of a Cut Seam

A droop or lip is a projection below the rim of the lid (Figure B.8). Droops and lips are caused by:

- first operation seaming roll too loose

- worn first operator roll groove

- body hook too long

- product trapped under lid

- can body out of round not cylindrical

- excess solder at body seam

- excessive amount or unequal distribution of end lining (rubber) compound.

A false seam is a seam or portion of a seam that is entirely unhooked as shown in Figure B.9. Causes are:

- mushroomed can flange

- bent can flange

- damaged or bent lid

- mis-assembly of can and lid. 


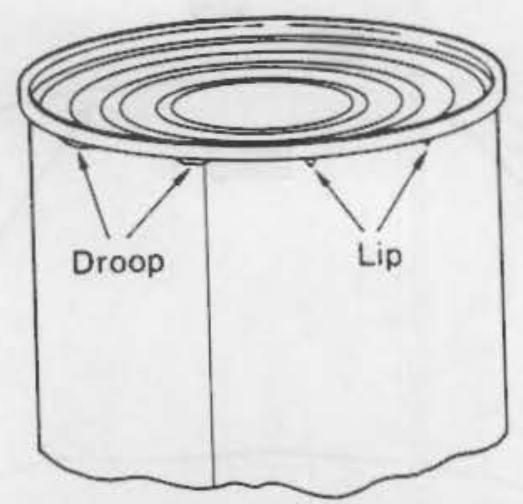

FIGURE B.8. Illustration of Droops and Lips

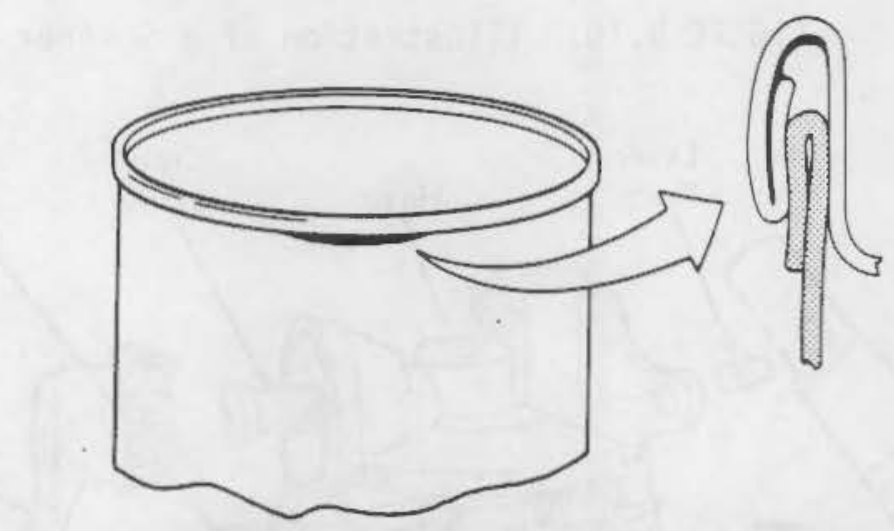

FIGURE B.9. Section View of a False Seam

An incomplete seam as shown in figure 8.10 is known as a spinner. The causes for this type of defect are:

- insufficient lifter pressure

- improper sealing of can lid in chuck

- worn chuck

- chuck set too high in relation to base plate

- seaming roll bending

- oil or grease on chuck

- excessive vertical play of chuck spindle.

The illustrated defects can be avoided if the can sealers are adjusted properly. The adjustment procedure will be outlined for the can sealer shown in Figures B.1 and B.2. The motorized can sealer (Figure B.3) adjustments are similar to the sealer shown in Figure B.2.

A detailed drawing of the small hand-operated can sealer is shown in Figure B.10. The first seaming roller is on the right side of the sealer (Figure B.11). 


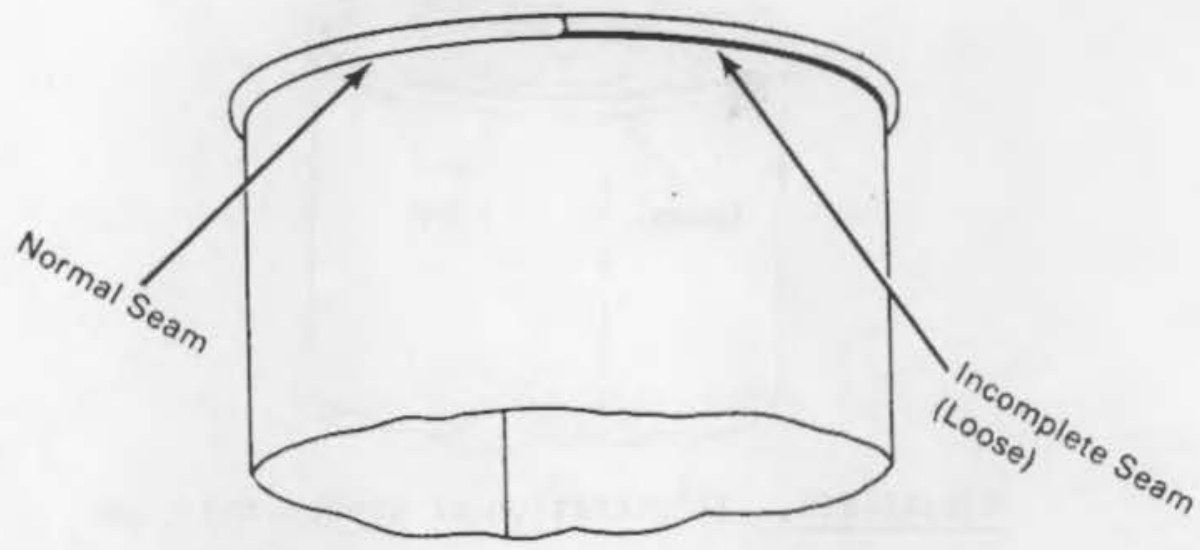

FIGURE B.10. Illustration of a Spinner

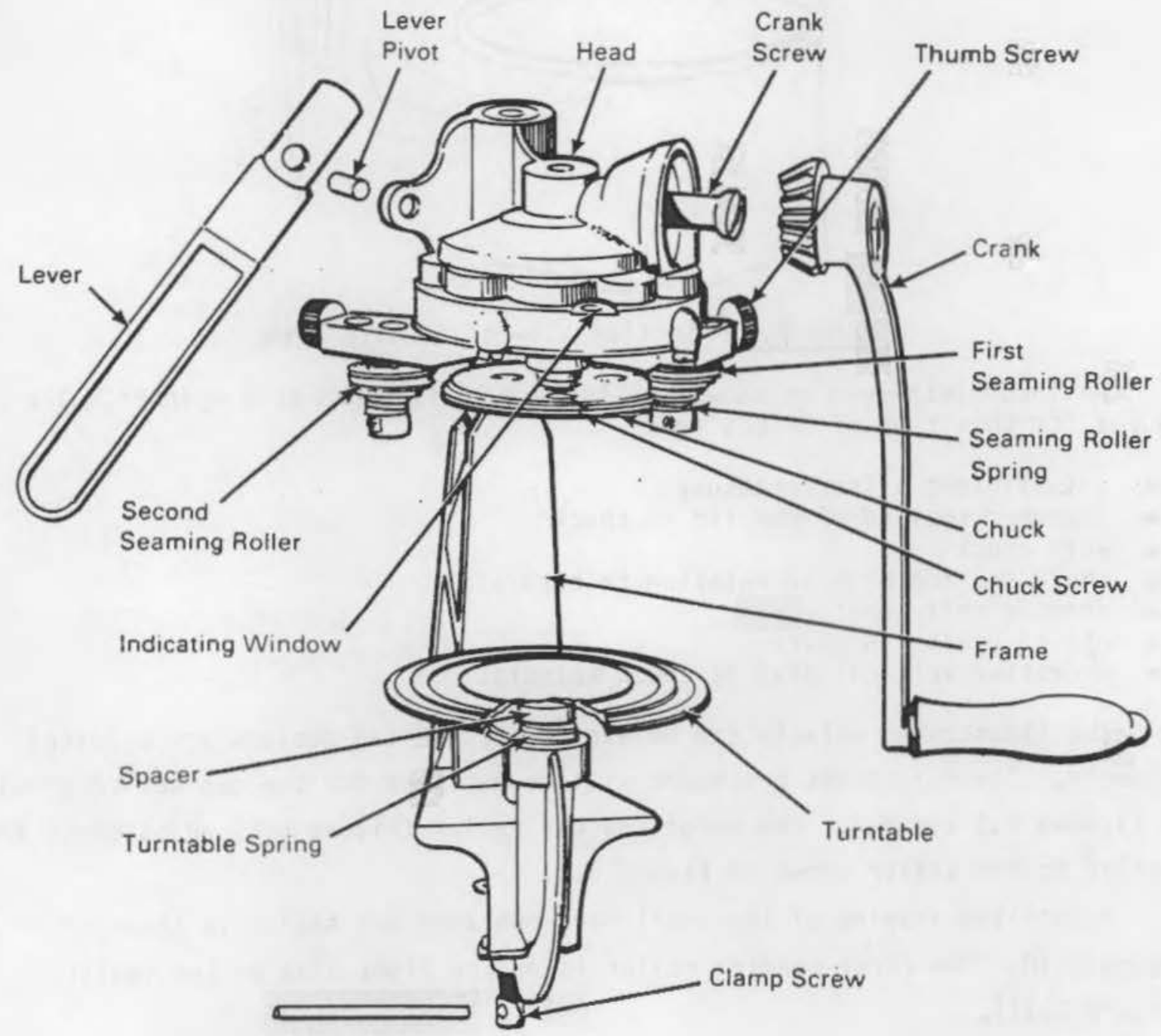

FIGURE B.11. Detailed Drawing of Hand-Operated Can Sealer 


\section{ADUSTMENT PROCEDURE}

1. Turn crank until " 1 " appears in indicating window (Figure B.12). Loosen the roller screw with the pin and loosen the thumb screw two or three turns.

2. Slide the seaming roller assembly back until the 3 -hole fixture touches the thumb screw or stops against the frame (Figure B.13).

3. Remove the pin and retighten the roller screw by hand.

4. Insert a wire gauge 0.069 inch (wire gauges are supplied with machine) in diameter between the chuck and the first seaming roller (Figure B.14).

5. Tighten the thumb screw until a drag is felt on the gauge wire as it is being pulled forward, then tighten the thumb screw with the pin.

6. Check to see that the gauge wire cannot be pulled out easily. If it can, loosen the roller screw slightly and tighten the thumb screw slightly.

7. Lock the roller screw in place and recheck to see that the gauge wire cannot be pulled out easily. If the gauge wire can be pulled out easily, repeat the previous steps until it cannot.

8. To remove the gauge wire, turn the crank clockwise.

9. After the adjustment is complete and the roller screw is locked into place, tighten the thumb screw.

The second seaming roller is on the left side of the sealer. Turn the crank until " 2 " appears in the center of the window. A smaller gauge wire 0.020 inch in diameter is used to adjust this seaming roller (Figure 8.14 ). Follow the same procedure used for the first seaming roller, except turn the crank counterclockwise to remove the gauge wire. Each time the chuck is changed and the seaming rollers moved to a different position to seal a different size can, the above procedure must be repeated. 


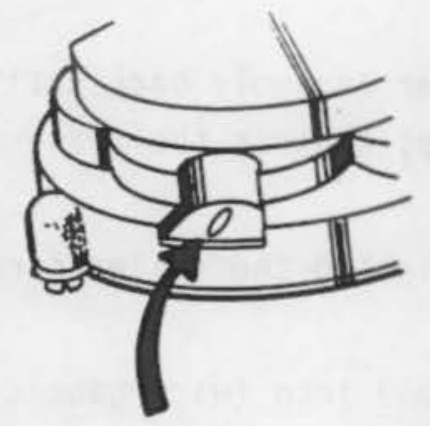

FIGURE B.12. Indicating Window on Hand-Operated Can Sealer

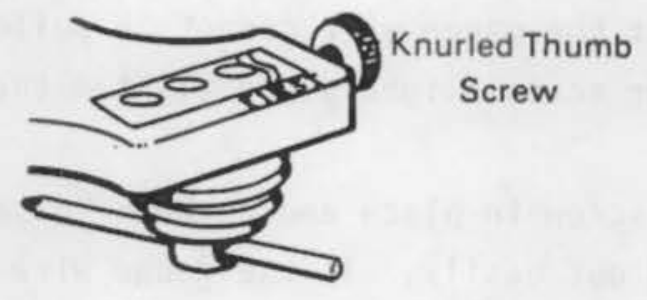

FIGURE B.13. First Seaming Role Fixture

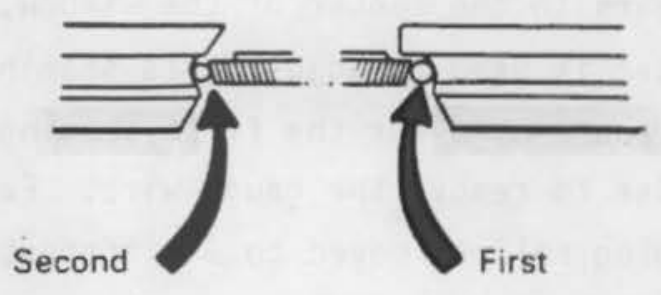

FIGURE 8.14. Position of Gauge Wires in Seaming Rollers 
It is also important to have the proper height adjustment so the can will not slip when it is being rotated on the turntable. Slippage of the can on the turntable is one of the main causes of spinners. Table B.l gives the proper spacer or washers to be used for the different size cans to be sealed.

The details of the hand-operated flywheel sealer are shown in figure 8.15. The first seaming roller is on the left (top, Figure B.16) and the second seaming roller is on the right (bottom, Figure B.16), just opposite of the small hand operated sealer previously described. When operating the sealer, make sure the flywheel is in the proper position. That is, if the flywheel is cranked in a clockwise rotation, the first seaming roller (one on left) should advance first. If it doesn' $\tau$, then remove the can and take out the chuck.

Crank the fly wheel until the first seaming roller advances, stop and crank the flywheel counterclockwise a couple of times or until the first seaming roller returns to its original position. Now the sealer is ready for sealing the can in the proper sequence.

The first item to check in the flywheel sealer is the space between the chuck and the top flange on the seaming rollers. To check this adjustement, push the chuck (Figure B.15) upward until it seats firmly and then turn the fly wheel until the seaming roller rests on top of the chuck. The clearance between the chuck and the top flange of the seaming roller should be about 0.001 inch. If the spacing needs to be adjusted loosen screw 9-LS (Figure B.16) and slide the roller up or down until proper spacing is achieved. Tighten screw 9-LS as tight as possible after alignment. This adjustment should be made to both seaming rollers.

TABLE B.1. Spacer and Seaming Roller Positions for Corresponding Can Sizes

$\begin{array}{lccc} & \begin{array}{c}\# 2 \text { Can } \\ (307 \times 409)\end{array} & \begin{array}{c}\# 2-1 / 2 \text { Can } \\ (401 \times 411)\end{array} & \begin{array}{c}\# 3 \text { Can } \\ (404 \times 414)\end{array} \\ \begin{array}{l}\text { Chuck size } \\ \text { Spacer Required - Thickness }\end{array} & \text { one }-5 / 16 " & \text { one }-3 / 16 " & 404 \\ \begin{array}{l}\text { Position of Seaming Roller } \\ \text { in 3-Hole Fixtures }\end{array} & \$ 2 \text { hole } & \# 2-1 / 2-3 \text { hole } \# 2-1 / 2-3 \text { hole }\end{array}$




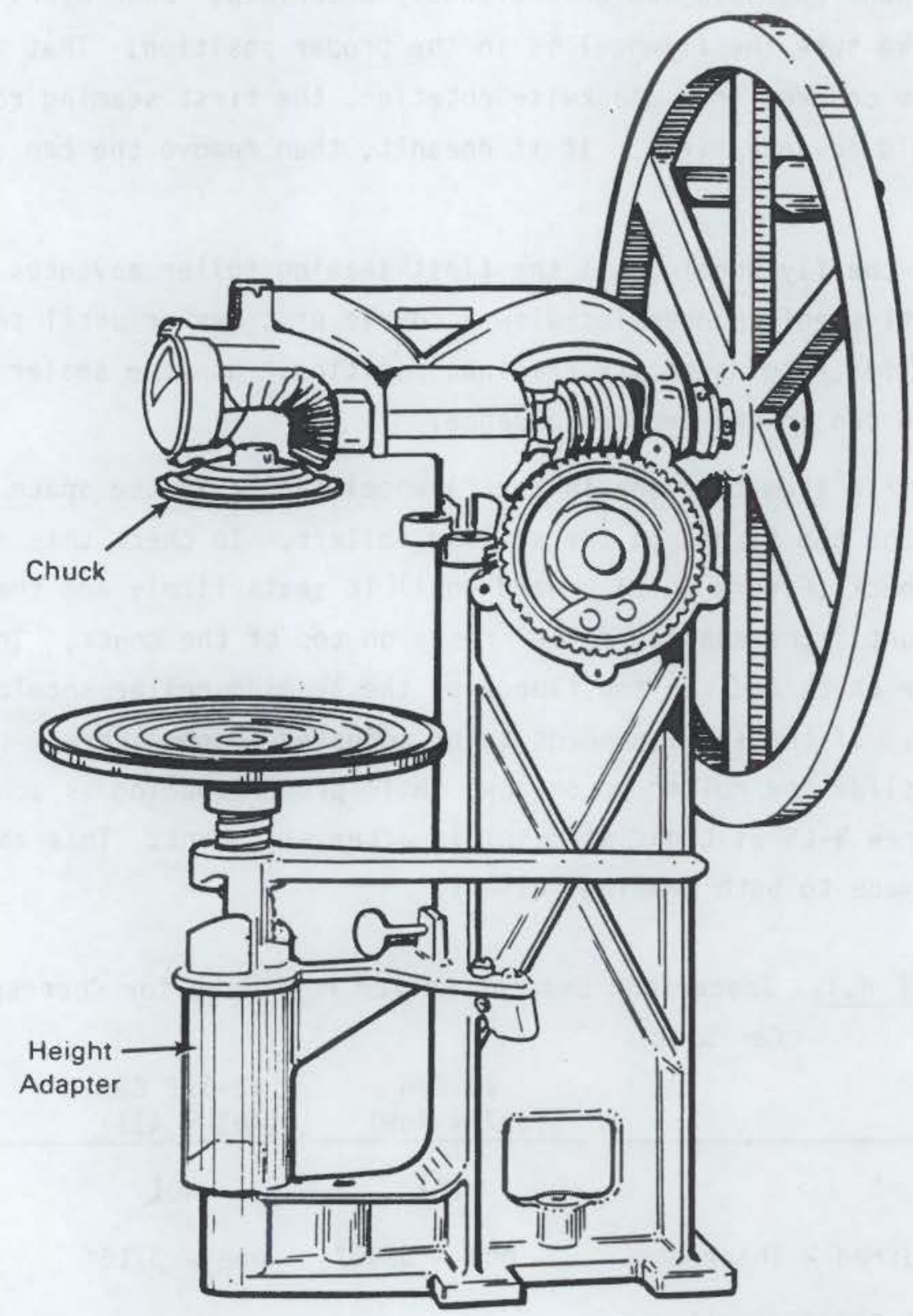

FIGURE B.15. Detailed Urawing of Hand-Operated Can Sealer with Flywheel 
Using the gauge shown in Figure B.17, check the seams of the can after each seaming operation. After sealing the can with only the first operation roll, slip the gauge over the seam. The groove marked first on the gauge should slide over the seam. If the gauge will not slip over the seam, tighten seaming roll by loosening the lock nut and adjusting the screw 24-AS (Figure 8.16). Tighten the screw a quarter of a turn to the right and recheck.

In order to check the seam, the can will have to be removed from the machine. To do this, back the tirst seaming roller away from the can by turning the fly wheel counterclockwise until the roller backs away from the chuck. After gauging the seam, place the can back on the turntable and reposition the can on the chuck by raising the turntable. If the gauge was too loose, then a new can must be used; whereas, if the gauge would not slip over the seam, the same can can be used.

After a proper first roll seam has been obtained, finish sealing the can with the second seam roller and check the seam with the groove marked second on the gauge. If the gauge will not slip over the seam, the roller must be adjusted by advancing the screw 24-AS (Figure B.16). If the seam is too loose, the screw must be backed off. However, if there is only a slight looseness the seam will usually be hermetically sealed.

The proper number of washers or height adapter (Figure B.15) must be used for the particular can being sealed. When a No. 3 can $(404 \times 411)$ is being sealed, use the height adaptor but no washers. If $A$ No. 3 tall can $(404 x$ 700 ) is being sealed, then the height adapter is removed and replaced by seven 1/4-inch washers. When sealing a No. $2-1 / 2$ size can $(401 \times 411)$, the height adapter plus a $3 / 16$-inch washer must be used.

The instructions and procedures presented are fairly complete to properly adjust the types of can sealers described; however, the complete instructions for the particular can sealer being used should be followed.

If poor seals are obtained after following the instructions, replacement parts may be needed. Usually, the items that need replacing the most frequently are the seaming rollers and the chucks. If you suspect this is the case, consult with the manufacturer of the can sealer for advice and for listings of current replacement parts. 


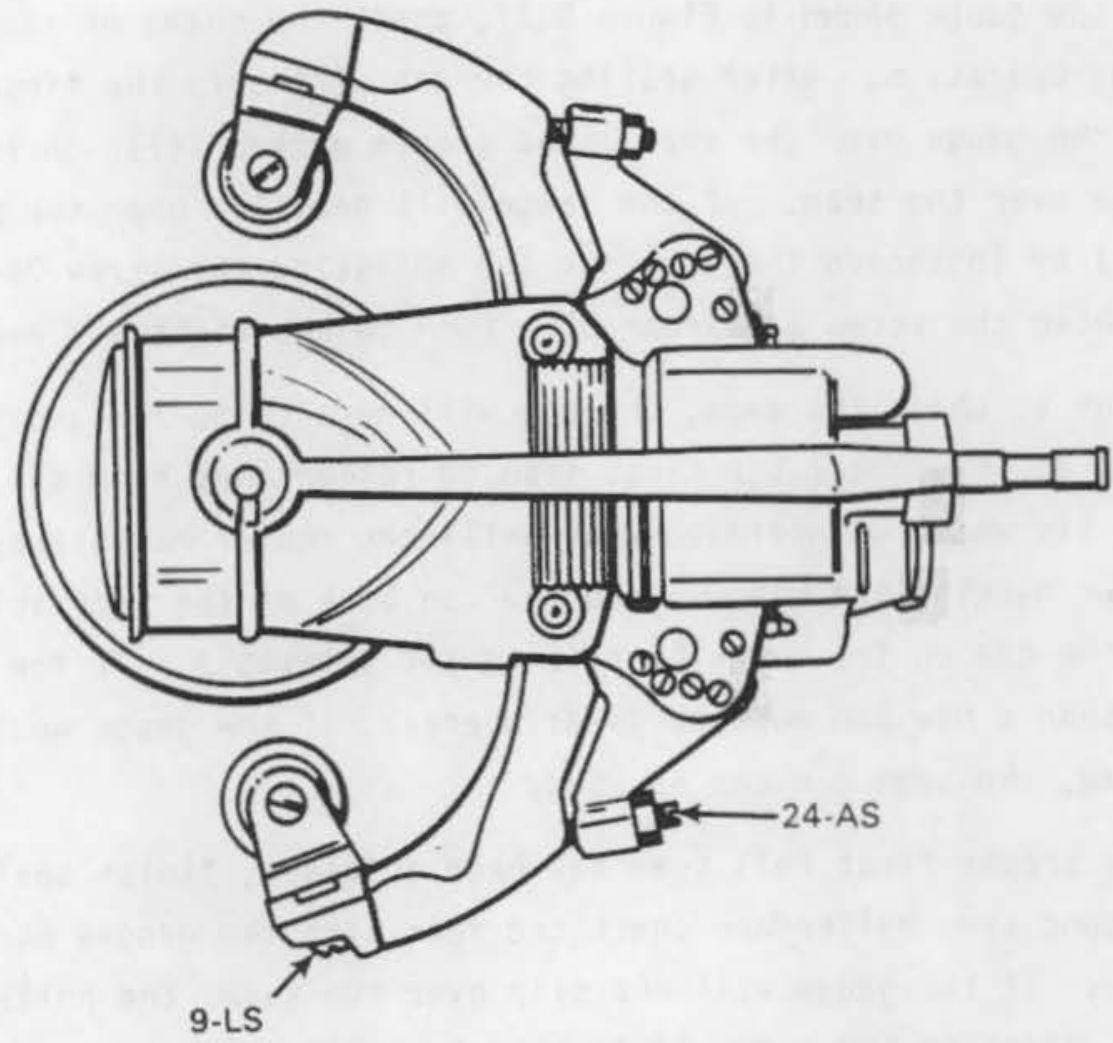

FIGURE B.16. Detailed Drawing of the Top View of a Hand-Operated Can Sealer with Flywheel

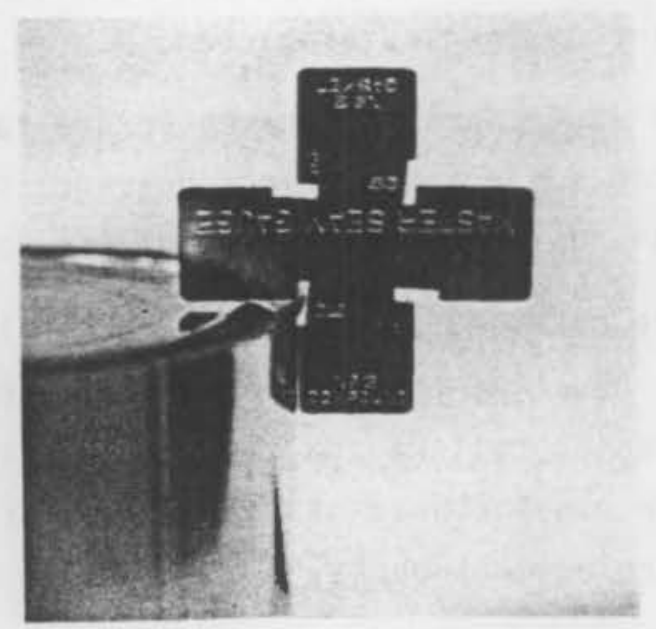

FIGURE B.17. Gauge Used to Check For Can Seam Specifications 
Additional inspection procedures are outlined in the American Can publication. Some of these procedures call for cutting through the seam to inspect the cross section of the seam. Usually, specialized equipment is needed to do this type of inspection. The real proof of the seam, however, is if it is hermetically sealed. This can be tested by placing the can in a vacuum bubble tester. Very small leaks $\left(\sim 10^{-5} \mathrm{cc} / \mathrm{sec}\right)$ can be detected using this technique. 
,

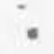
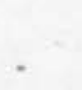

.

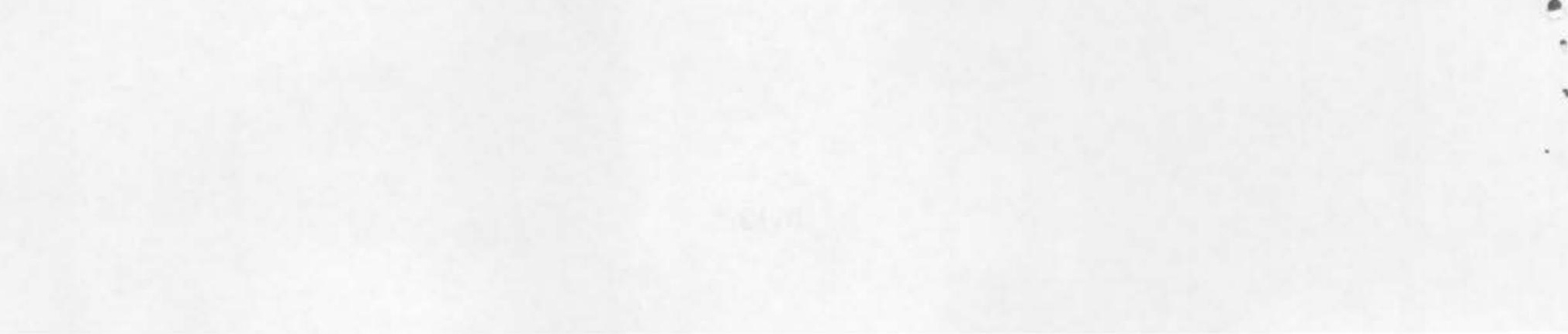




\section{APPENDIX C}

OPERATING PROCEDURES 
APPENDIX C

OPERATING PROCEDURES

These operating procedures are provided to establish methods for assuring that gas tight seals are obtained with $2 R$ vessels having pipe thread closures and metal food pack cans having mechanical crimped seals.

\section{PROCEDURE FOR SEALING $2 R$ VESSELS WITH THREAD CLOSURES}

1. Visually inspect threads on the $2 R$ pipe body and pipe cap or plug. If the thread is damaged such that the damage is continuous from the bottom of the thread to the top, reject the part. Repair minor damage by using a thread dressing tool.

2. Clean threads using a degreasing agent such as trichloroethylene or trichloroethane. If the threads have silicone rubber attached to them, soak the threads for 12-14 hours in xylene and then rinse in one of the above degreasing chemicals and wire brush.

3. Coat the threads of the pipe body and pipe cap or plug with a liberal amount of Hi-Temp G.E. silicone gasket material (GEC 56002). Make sure that all the threads are covered with the silicone rubber.

4. Place pipe body in vice and secure the pipe so it will not slip during tightening of cap or plug.

5. Thread cap or plug onto the pipe body by hand to make certain the cap or plug is engaging the pipe body properly.

6. Using a torque wrench with a pipe cap clamp or plug fixture, torque the caps or plugs to $200 \mathrm{ft}-\mathrm{lbs}$.

7. Allow the silicone gasket material to set up for 12 hours. 
8. Check the seal using a vacuum bubble tester. If no streaming bubbles are observed the seal is gas tight.

PROCEDURE FOR SEALING MECHANICALLY SEALED CANS

1. Inspect can body to make certain it is not dented or damage.

2. Inspect the flange on the can body. If the flange has been severely bent or creased it should not be used. Small creases can usually be straightened by using needle nose pliers. Run your finger around the flange to make certain it is smooth and no discontinuities are present. Generally, there is a small ridge in the flange where the side seam intersects it. If the ridge is quite abrupt, smooth it of carefully with a fine tooth jeweler's file.

3. Inspect the lid and make sure the rim where the rubber compound has been applied is smooth and uniform. There should be no exposure of metal showing through the rubber compound. If there are scratches, shiny spots (metal showing through), discard the lid. Also, make sure the curl or roll over at the rim of the lid is uniform and not dented.

4. Place the lid on the can and check to see that the lid is seated properly. The curl on the rim of the lid should be below the flange on the can. Do not rotate the lid or the rubber compound may be scratched or damaged.

5. Center the cans on a properly adjusted can sealer (see Appendix B). Rotate the base plate to make certain the can is centered.

6. Raise the can, making sure the lid to be sealed is properly engaged in the chuck. Position the can so that the part of the lid directly over the side seam on the can does not contact the seaming roller first. 
7. Before cranking the handle of the sealer (motorized can sealers return to correct starting position automatically), make certain that the seaming rollers are in the proper starting position (see Appendix B for discussion on properly setting up sealer).

8. Crank the handle in a clockwise direction. Try to maintain a uniform rotation throughout the sealing operation. If a motorized can sealer is being used, only use one complete cycle to seal the cans. Repeating the cycle will not provide better seals but may degrade the first sealing operation.

9. Lower the turntable and remove the can if the can is struck on the chuck. The second seaming roller is set too tight.

10. Visually examine the can for obvious defects as illustrated in Appendix B. If defects are present, the can sealer is out of adjustment and it must be fixed.

11. If the seal looks good, bubble test the can. If no bubbles are observed, the can is hermetically sealed. If small leaks are observed, these can be sealed by applying silicone rubber compound around the seam of the can, allow 12 hours for the compound to dry. Leak check again and if bubbles appear, apply another thin coat of silicone compound. Application of the silicone rubber is an effective way to stop leaks in the manufacturer's seams. However, a properly adjusted sealer will produce seams that don't leak. 

No. of

Copies

OFFSITE

30 DOE Technical Information Center

F. E. Adcock

Rockwell International, Rocky

Flats Plant

P.0. Box 464

Golden, CO 80402-0464

G. Allen

Division 6323

Sandia National Laboratory

P.0. Box 5800

Albuquerque, NM 87185

F. M. Almeter

U.S. Department of Energy

DP-4.2, GTN

Washington, OC 20545

W. Bateman

International Energy

Associates Ltd.

2500 Virginia Avenue, NW

Washington, DC 20057

J. M. Cece

U.S. Department of Energy

EH-122, GTN

Washington, DC 20545

G. G. Chalfant

duPont, Savannah River Plant

Building 723-9A

Aiken, SC 29808

D. A. Edling

Mound - MRC

P.0. Box 31

Miamisburg, $\mathrm{OH} 45342$

K. E. Elliott

U.S. Department of Energy, Albuquerque Operations office

Environmental, Safety and Health Division

P.0. Box 5400

Albuquerque, NM 87115
F. D. Falci

U.S. Department of Energy

$\mathrm{DP}-123$

Washington, DC 20545

L. Gage

Quality Engineering Division

Albuquerque Operations office

P.0. Box 5400

Albuquerque, NM 87115

K. Golliher

U.S. Department of Energy, Albuquerque Operations of fice

Environmental, Safety and Health Division

P.0. Box 5400

Albuquerque, NM 87115

R. D. Hahn

DP-22.2 Military Application

U.S. Department of Energy

Washington, DC 20545

C. Henn

Quality Engineering Division

Albuquerque Operations office

P.0. Box 5400

Albuquerque, NM 87115

N. King, Jr.

$\mathrm{P}-229$

Los Alamos National Laboratory

P.0. Box 1663

Los Alamos, NM 87545

D. M. Krieg

Rockwell International, Rocky Flats Plant

P.0. Box 464

Golden, CO 8D402-0464

R. E. Luna

Division 6321

Sandia National Laboratory

P.0. Box 5800

Albuquerque, 87185 
G. W. May

Quality and Materials Assurance Division

Department of Energy

Savannah River Operations office P.0. Box A

Aiken, SC 29802

C. J. Mauch

U.S. Department of Energy

DP-122.2

Washington, DC 20545

J. D. McClure

Division 6321

Sandia National Laboratory

P.0. Box 5800

Albuquerque, NM 87185

E. M. Roybal

U.S. Department of Energy, Albuquerque Operations office

Environmental, Safety and. Health Division

P.0. Box 5400

Albuquerque, NM 87115

P. A. Saxman

U.S. Department of Energy, Albuquerque Operations office Environmental, Safety and Health Division

P.0. Box 5400

Albuquerque, NM 87115

D. R. Smith

F-691

Los Alamos National Laboratory

P.0. Box 1663

Los Alamos, NM 87545

\section{ONSITE}

4 DOE Richland Operations Office

E. M. Bowers

K. W. Bracken

R. M. Hiegel

H. E. Ransom
2 Rockwell Hanford

D. L. McCall

R. W. Szempruch

21 Pacific Northwest Laboratory

J. T. Denovan

S. C. Hawley

R. R. King

C. R. Richey

J. M. Taylor (10)

Publishing Coordination (2)

Technical Information (5) 
